2

in. 77

(196)

$B 8383$

ORNL-5821

om i

OAK

RIDE'

NATIONAL

LABORATORY

UNION

CARBIDE

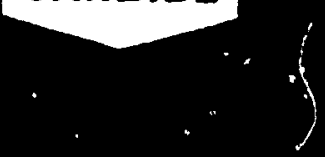

MASTER

Industrial Safety and Applied Health Physics Annual Report for 1980

OPERATED BY

UNION CARBIDE CORPORATION

FOR THE UNITED STATES

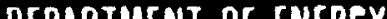


Contract No. W-7405-eng-26

INDUSTRIAL SAFETY AND APPLIED HEALTH PHYSICS AMIUAL REPORT FOR 1980

J. A. Auxier, Director

J. M. Davis, Associate Direcror

Date Published: November 1981

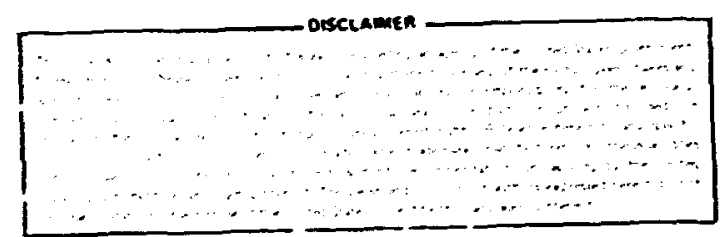

wothes This document comaine informosion of a pretiminary noture. It is exbiect to revieion or correction and therefore does not represemt a final report.

OAK RIDGE NATIONAL LABORATORY

Oak Ridge, Tennessee $\mathbf{3 7 8 3 0}$

operated by

UNION CARBIDE CORPORATION

for the

DEPARTMENT OF ENERGY 
TAELE OF CONTENTS

Foreword . . . . . . . . . . . . . . . $\frac{\text { Page }}{\mathrm{v}}$

1.0 ORgnizational chart. ................ vii

2.0 sumarr ..................... 1

3.0 RADIATION MONITORING. ............... 4

3.1 Personnel Nonituring ...............4 4

3.2 Health Physics Instrumtation .......... 7

3.3 Developments ................ 8

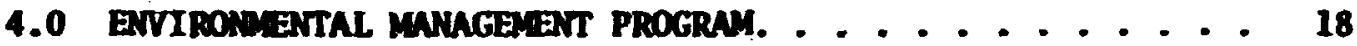

4.1 Departwent of Environmental Managenent ....... 18

4.2 Office of Environaental Coordinator. . . . . . . 20

4.3 Atmospheric Monitoring . . . . . . . . . . . 21

4.4 Water Monitoring ................ 23

4.5 Radiation Background Measurements. . . . . . . . 25

4.6 Soil and Crass Sarples ............... 25

4.7 Deer Samples ................. 25

4.8 Calculation of Potential Radiation Dose to the

Public .................. 25

4.9 Environmental Monitoring Samples......... 28

4.10 Highlights of Other Major Activities of the

Environmental Managenent Progran ......... 28

5.0 RADIATION AND SAFETY SURVEYS ........... 78

5.1 Laboratory Operations Monitoring ......... 78

$5.2 \times$ Ray \& Microwave Safety Prograns . . . . . . . . 84

5.3 Laundry Monitoring Facility ............ 84

5.4 Radiation Incidents .............. 85

6.0 INDUSTRIal SAFetY ANd SPECIAL PROJECTS. . . . . . . . 86

6.1 ORNL Safety Progran Activities - 1980. . . . . . 86

6.2 Accident Analysis. . . . . . . . . . . . 88

6.3 Sumary of Disabling Injuries .......... 89

6.4 Safety Awards. . . . . . . . . . . 89

6.5 L ng Range Plans for Industrial Safety ....... 89

7.0 OFFICE OF OPERATIONAL SAFETY. . . . . . . . . . 102

7.1 Laboratory Director's Review Combittees. . . . . . . 102

7.2 Implementation of the DOE Manual Chapter 0531 and DOE

Order 5481.1 Requirements. . . . . . . . . . . 103

7.3 RCO-DSO Activities . . . . . . . . . . . . . 103

7.4 Staff Consultation, Review, and Other Activities . 104

7.5 summary. . . . . . . . . . . . . . . 105

8.0 TRAINING, LECTURES, PUBLICATIONS, AND PROFESSIONAL

ACTIVITIES ................... 113 
FOREMORD

This report is a description and sumary of the activities of the Industrial Safety and Applied Health Physics Division. Information in this report was contributed by, and/or comiled by the staff members of the following departments of the Industrial Safety and Applied Health Physics Division.

Health Physics Department

Safety Department

Enviromental Management Department 


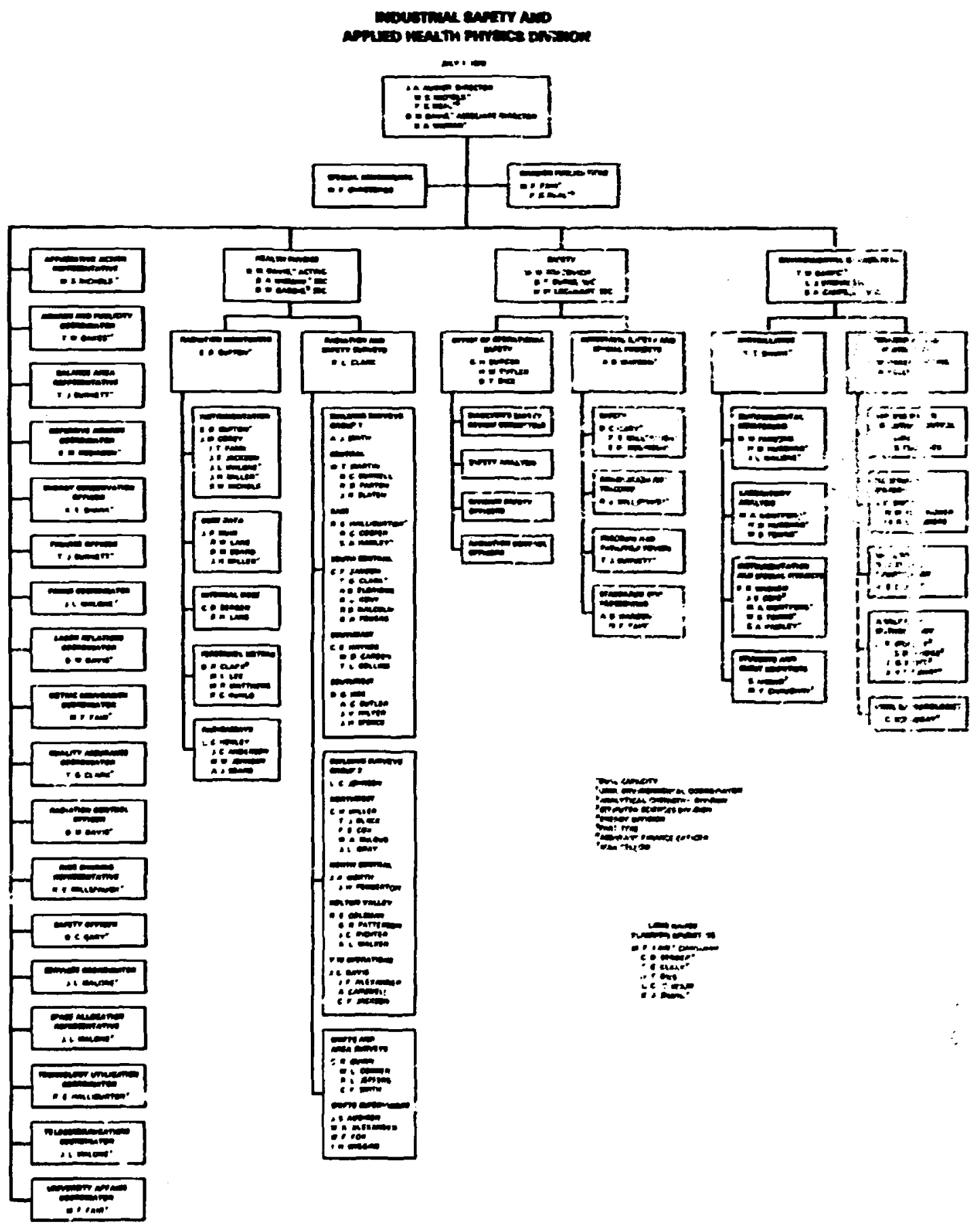




\subsection{SUMARY}

\section{Radiation Quantities and Units}

The four radiation quantities (and units) used in this report are: exposure (roentgen and coulomb per kilogran), absorbud dose (rad and gray), dose equivalent (rem and sievert), and activity (curie and becquerel). The term "dose" shall nean dose equivalent.

\section{RADIATION MONITORING}

\section{Personnel Monitoring}

There were no external or internal exposures to personnel which exceeded the standards for radiation protection as defined in DOE Manial Chapter 0524. Only 35 eaployees received whole body dose equivalents of $10 \mathrm{mSv}$ ( $1 \mathrm{rem}$ ) or greater. The highest whole body dose equival ent to an employee was about $29 \mathrm{mSv}(2.9 \mathrm{rem})$. The highest internal expcsure was less than one-half of a maximum permissible dose for any calendar quarter.

\section{Health Physics Instrumentation}

During 1980, 26 portable instruments were added to the inventoiy and 25 retired. The total number in service on January 1, 1981, was 979. There were 25 facility radiation monitoring instruments installed and 14 retired during 1980 . The total number in sesvice on January 1,1981 , was 1,032 .

\section{ENVIRONS SURVEILLANCE}

\section{Atmospheric Monitoring}

There were no releases of gaseous waste from the Laboratory which were of a level that required an incident report to DOE. The average concentration of beta radioactivity in the atmosphere at the perimeter of the DOE-controlled area was less than one tenth of one percent of the value applicable to releases to uncontrolled areas.

\section{Water Monitoring}

There were no releases of liquid radioactive waste from the Laboratory which were of a level that required an incient report to DOE. The quantity of those radionuclides of primary concern in the Clinch River, based on the concentration measured at White Oak Dam and the dilution afforded by the Clinch River, averaged 0.16 percent of the concentration guide. 


\section{Radiation Background Measurements}

The average background level at the PAM stations during 1980 was $9.0 \mathrm{\mu rad} / \mathrm{h}(0.090 \mathrm{\mu G} / \mathrm{h})$.

\section{Soil and Grass Saples}

Soil samples were collected at all perimeter and remote monitorin: stations and analyzed for eleven radionuclides including plutonium ard uranium. Plutonium-239 content ranged from $0.37 \mathrm{~Bq} / \mathrm{kg}(0.01 \mathrm{pCi} / \mathrm{g})$ to $1.5 \mathrm{~Bq} / \mathrm{kg}(0.04 \mathrm{pCi} / \mathrm{g})$, and the Uranium-235 content ranged from $0.7 \mathrm{~Bq} / \mathrm{kg}(0.02 \mathrm{pCi} / \mathrm{g})$ to $16 \mathrm{~Bq} / \mathrm{kg}(0.43 \mathrm{pCi} / \mathrm{g})$.

Grass samples were collected at all perimeter and remote monitoring stations and analyzed for twelve radionuclides incliding plutoniun and uraniug. Plutoniun-239 content ranged from $0.04 \mathrm{~Bq} / \mathrm{kz}(0.001 \mathrm{pCi} / \mathrm{g})$ tr $0.07 \mathrm{Br} / \mathrm{kg}(0.002 \mathrm{pCi} / \mathrm{g})$, and the Uranium-235 content ranged from $0.37 \mathrm{PA} / \mathrm{kg}(0.01 \mathrm{pCi} / \mathrm{g})$ to $12 \mathrm{~Bq} / \mathrm{kg}(0.33 \mathrm{pCi} / \mathrm{g})$.

\section{RADIATION AND SAFETY SURVEYS}

\section{Laboratory Operations Monitoring}

During 1980, the Radiation and Safety Surveys personnel continued to assist the operating groups in keeping contamination, air concentrations, and personnel exposure levels below the established maximum permissible levels. They assisted in reducing or eliminating a number of problems associated with radiation protection at the Laboratory.

\section{Radiation Incidents}

Five radiation incidents involving radioactive materials were recorded during 1980. All were of minor significance.

Laundry Monitoring

Of the 570,000 articles of wearing apparel and 214,000 articles, such 35 mops, laundry bags, towels, etc., monitored during 1980 about five percent were round to be contaminated.

\section{INDUSTRIAL SAFETY AND SPECIAL PROJECTS}

\section{Accident Analysis}

Two lost workday cases occurred at ORNL in 1980, an incidence rate of 0.05 . The Recordable Injury and Illness frequency rate for 1980 was 0.96 . The frequency rates for 1979 were 0.07 and 1.05 , respectively. 


\section{Sumary of Lost Workday Cases}

A total of 147 days were lost or charged for the two lost workday cases in 1980. The days lost or cliarged in 1979 were 69 for three lost workday cases and 55 in 1978 for three lost workday cases.

\section{Safety Awards}

The National Safety Council Award of Honor was earned by the Laboratory in 1980. This is the sixth consecutive year the Laboratory has earned this award. The Laboratory also earned DOE's Award of Excellence. 


\subsection{RADIATION MONITORING}

\subsection{Personnel Monitoring}

All persons who enter Laboratory areas where there is a likelihood of exposure to radiation or radioactive materials are monitored for the kinds of exposure they are likely to sustajn. External radiation dosimetry is accomplished mainly by means of badge-meters, pocket ion chanbers, and hand exposure meters. Internal deposition is determined from bioassays and in vivo counting.

\subsubsection{Dose Analysis Sumary, 1980}

(a) External Exposuras - No employee recaived a whole body radiation dose which exceeded the standar's for radiation protection, DOE Manual Cl.apter 0524. The maximum whole body dose sustained by an employee was shout $31 \mathrm{mSV}(3.1 \mathrm{rem})$ or 62 percent of the applicable standard of $5 \mathrm{C}(5 \mathrm{rem})$. The range of doses to persons using ORNL badgemeters is snown in Table 3.1.1.

As of December 31, 1980, no employee had a cumulative whole body dose which was greater than the applicable standard based on the age proration formula $5(\mathrm{~N}-18)$, Table 3.1.2. No employee has an average annual dose that exceeds $0.05 \mathrm{~Sv}(5 \mathrm{rem})$ per year of employment, Table 3.1.3. The greatest cumulative whole body dose received by an employee was approximately $1.13 \mathrm{~S}$ " (113 rem). This was accrued over an cmployment period of about 37 years and represents an average or about $31 \mathrm{mSv}$ (3.1 rem) per year.

The greatest cumulative dose to the skin of the whole body received by an employee during 1980 was about $93 \mathrm{mSv}(9.3 \mathrm{rem})$ or 62 percent of the applicable standard of $150 \mathrm{mSv}$ (15 rem).

The maximum cumulative hand dose recorded during 1980 was about $110 \mathrm{mSv}$ (11 rem) or 15 percent of the applicable standard of $750 \mathrm{mSv}$ (75 rem).

The average of the 10 greatest whole body doses to ORNL employees for each of the years 1976 through 1980 is shown in Table 3.1.4.

(b) Internal Exposures - There were no cases of internal exposure during th:e year for which the radioactive material within the body averaged as much as one-half the maximum permissible organ burden for the year. 


\subsubsection{External Dose Technuques}

(a) TLD Meters - Standard TLD meters are issued to all employees and to photobadged non-emp -oyees who work in radiation zones. Standari TLD neters have two TL chips, one shielded and one unshielded. Specialized meters, with various complements of TLDs and films are issued to those who may be exposed to other than gama and energetic $X$ radiation.

TLD meters of radiation workers are exchanged and processed quarterly, or more frequently if required for exposure cont:ol. All other neters are exchanged and processed annually.

(b) Pocket Meters - Pocket meters (indirect reading, ionization chambers) are made available at all principal points of entry to ORNL. A pair of pocket meters is carried for the duration of a work shift by persons wio work in an area where the potential $f_{i} r$ an exposure of $0.2 \mathrm{mGy}(20 \mathrm{mrad})$ or more exists during the work : iff. Pocket meter pairs are processed each day by Health Physics technicians. Readings of $0.2 \mathrm{mGy}(20 \mathrm{mrad})$ or more are reported to supervision daily. Printouts giving all readings along with weekly totals and accumulative totals are sent to supervision weekly. Pocket meter readings are used fo: estimating integrazed exposure and as a basis for badge-meter processing during a calendar quarter.

(c) Hand Exposure Meters - Hand exposure meters are TLD-loaded finger rings. Hand exposure meters are issued to persons for use during operations where it is likely that the hand cose may exceed $10 \mathrm{mSv}$ (1 rem) during the week. They are issued and collected by Radiation and Safety Surveys personnel who determine the need for this type of monitoring and arrenge for a processing schedule.

(d) Metering Resunz - Shown in Table 3.1 .5 are the quantities of personnel metering devices used and processed during 1980. The number of dosimeters processed is less than the number issued, because those which were issued for accident dosimetry only were not processed unless there was a likelihood of exposure.

\subsubsection{Internal Dose Techniques}

(a) Bjoassay - Urine and fecal samples are analyzed for the purpose of making internal exposure determinations. The frequency of sampling and the type of radiochemical analysis performed is based upen each specific radioisotope and the intake putential. Because of the small quantities of radioactive material in most samples, qualitative analyses are not feasible; and only quantitative analyses for predetermined iso. topes are performed routinely. 
In most cases, bioassay data requize interpretation to deternine the dose to the person; computer frograns are used for evaluation of extensive data on urinary excretion of ${ }^{239} \mathrm{Pu}$. An estinate of dose is ade for all cases in wich it appears that one-fourth of a maximun rermissible organ burden averaged over a calendar year may be exceede1.

The analyses perforned by the Industrial Safety and Applied Health pnysics radiochemical lab during 1980 are sumearized in Table 3.1.6.

(b) Whole Body Counter - The Whole Body Counter (an in vivn gama spectroneter) is used for estinating internally deposited quantities of nost radionuclides wilch emit photons.

Approximately 750 whole body, chest, wound, thyroid and liver counts were perforned by the Whole Body Counter facility during the year 1980. Wost of the subjects counted had ${ }^{137} \mathrm{Cs}$ in the range of 37 to $500 \mathrm{~Bq}$ (frow fallout from muclear weapons testing). Small quantities of various fission or activation products were identified in a few individuals, but no indjvidual was found to have an internal deposition of greater than 10 percent of maximu permissible organ burden of that isotope for the year.

(c) Counting Facility - The counting facility deternines radioactivity content of samples subnitted by the Industrial Safety and Applied Health Physics sections. A sumary of anaiyses is in Table 3.1.7.

\subsubsection{Reports}

Routine reports of personnel ronitoring data are prepared and distributed to divisional supervision and to the Industrial Safety and Applied Health Physics staff.

(a) Pocket Meter Data - A report is prepared and distributed to supervision daily of the names, ORNL divisions, and readings for pocket meters which were $0.2 \mathrm{wg}$ (20 mrad) or greater during the previous 24 hours.

A computer-prepared report, which includes all pocket meter data for the previous week and sumary data for the calendar quarter, is published and distributed weekly.

(b) External Dosinetry Data - A computer-prepared report, which includes data of recorded skin dose and whole body dose for the previous calendar quarter and totals for the current year, is published and distributed quarterly. 
(c) Bioassay Data - A computer-prepared report, which includes data of sample status and results for the p-evious week, is pitblished and distributed weekiy. A guarterly and an annual report of results are prepared and distributed also.

(d) Whole Body Counter Dats - Preliminary results of analysis are reported on a card form soon after counting is done. A computerprepared report is published and distributed quarterly and annually.

\subsubsection{Record:}

Permanent records of personnel monitoring data are waintained for each person who is assigned an ORNL photobadge meter.

\subsection{Healtr Physics Instrumentation}

The Industrial Safety and Applied Health Physics Division shares with the Instrumentation and Controls Division the responsibility for the selection of electronic ratiation monitoring instruments usid in the ORNL health physics program. Normally, the Industrial Safety and Applied Health Physics Division is responsible for determining the need for new instrument types and modificatior.s to existing types, for specifying the health physics design requirements, and for approval of the design. The Industrial Safety and Applied He. Ith Physics Division is responsible for calibrating all instruments used in the health physics program and is allocated the funds for maintenance of these instruments. Maintenance is performed or cross-ordered by the Instrumentation and Controls Division.

Non-electronic personnel monitoring devices are Jesigned, tested, calibrated, and maintained by Industrial Safety and ripplied Health Physics Division personnel.

\subsubsection{Instrum.ent Inventory}

The electroni:- instrumeri:s used in the health physics program are divided, for convenience in servicing and calibrating, into two classes: the first class includes battery-powered portable instruments; the second class $j$ :acludes the stationary instruments that are AC powert. Portable instruments are assigned and issued to the Radiation and Safety Surveys complexes. Stationary instruments are the property of tiie ORNL division which has the monitoring responsibility in the area in which the instrument is located. Table 3.2 .1 lists portable initruments assigned at the end of 1980; Table 3.2.2 lists stationary instruments in use at the end of 1980 . 
Invertory and service simmaries for health physics instruments ar prepared by computer. These computer-programmed reports enable the Instruments Group to maintain a current inventory ou most health physics instrument requirenents.

The allocation of stationary health physics monitoring instruments by division is shown in Table 3.2.3.

\subsubsection{Calibration Facility}

The Industrial Safety and Applied Health Fhysics Division maintains a calibration facility for the caibration and maintenance of portable radiation instruments and personne: metering devices. The facility is equipped lith calibration sources, remote control devices, and shop space for the use of Instrumentation and Controls Division maintenance personnel. Industrial Safety and Applied Health Physics personnel assign, arrange for maintenance of, calibrate, prcvide delivery services for, and maintaic inventory and servicing data on all portable health physics instruments.

The radiation sources used for calioratinn huve been either standardized by the National Bureau of Standards or eraluated by comparison witt. source: $z$ that have been standardized by the National bureau of Standards.

The recomended maintenance and calibration frequency is two (no more than three) months for instruments that measure exposure, absorbed dose or dose equivalent rates--Cutie Pie, Juno, Fist Neutron Survey Meter, etc., and three (no more than four) months for count raie instruments-Gas Flow, Scintillation, RMSM, Thermal Neu=ron, Air Proportional, etc. The number of calibrations of portable instrunent; for 1980 is shown in Table 3.2.4.

\subsection{Developments}

\subsubsection{Hyperpure Germanium Array for Lung Counting}

The ORNL Whole Body Counter inf contirued development of the $80 \mathrm{~cm}^{2}$ solid state (hyperpure germanium) array for in-vivo detection of low-energy photon and $X$-ray emitters in 1980. Computer programs for analysis of lung burdens of ${ }^{239} \mathrm{Pu}$ and ${ }^{241} \mathrm{Am}$ and prediction of background continuums were written based on data acquired from uncontaminated male and female subjects. A nuclide library was compiled for some of the most comoniy occurring nuclides and was incorporated into computer programs for rapid identification and quantification of these radionuclides. 


\subsubsection{Calcium Fluoride-Sodiun Iodide Phoswich for Sample Analysis}

Experimentation was begun on a $\mathrm{CaF}_{2}(\mathrm{Eu})-\mathrm{NaI}(\mathrm{TI})$ phoswich for betayama spectroscopy of environmental samples. Preliminary investigation on soil samples has been encouraging. Although improvements are still being made, this phosirich system currently demonstrates a reduction in the ninimum detectable activity by a factor of approximately 10-20 for ${ }^{239} \mathrm{Pu}$ in $20 \mathrm{~g}$ samples of soil--aiso containing mixed fission products-over existing detector systens (e.g., FIDLER AND ZnS detectors). Upon completion of laboratory experimentation, the possibility of turning this system into a field instrument--useful for ground surveys and decontamination and decomaissioning work--will be investigated.

\subsubsection{Sample Counting Standards}

All calibrition sources for the Counting Facility were restandardizad by rompaison with sources standardized by the National Bureau of Standards.

\subsubsection{Bioassay Standards}

Solutions containing radioactivity that are used for tracers and control standards for bioassays were restandardized by comparison with solutions standardizei by the National Burcau of Standards, if available, or by other means if not. 
Table 3.1.1 Dose Data Sumary for Laboratory Population Involving Exposure to Thole Body Radiation - 1980

\begin{tabular}{|c|c|c|c|c|c|c|c|c|c|}
\hline \multirow[b]{2}{*}{ Group } & \multirow[b]{2}{*}{$\begin{array}{l}\text { usy } \\
\text { rean }\end{array}$} & \multicolumn{7}{|c|}{ Dose Range } & \multirow{2}{*}{ Total } \\
\hline & & $\begin{array}{c}0-1 \\
0-0.1\end{array}$ & $\begin{array}{r}1-10 \\
0.1-1\end{array}$ & $\begin{array}{c}10-20 \\
=-2\end{array}$ & $\begin{array}{c}20-30 \\
2-3\end{array}$ & $\begin{array}{c}30-40 \\
3-4\end{array}$ & $\begin{array}{c}40-50 \\
4-5\end{array}$ & $\begin{array}{l}50 \text { up } \\
5 \text { up }\end{array}$ & \\
\hline \multicolumn{2}{|c|}{ CRNL Euployees } & 364 & 243 & 35 & 10 & 1 & $\mathbf{0}$ & $\mathbf{0}$ & 653 \\
\hline \multicolumn{2}{|c|}{$\begin{array}{l}\text { ORNL-Moni tored } \\
\text { Non-Employees }\end{array}$} & 300 & 25 & $\mathbf{0}$ & $\mathbf{0}$ & $\mathbf{0}$ & 0 & 0 & 325 \\
\hline \multicolumn{2}{|l|}{ TOTAL } & 664 & 208 & 35 & 10 & 1 & $r$ & 0 & 978 \\
\hline
\end{tabular}

Table 3.1.2 Average Dose Per Year Sinct: Age 18 - 1980

\begin{tabular}{|c|c|c|c|c|c|c|c|c|}
\hline \multirow{2}{*}{ Group } & \multirow[b]{2}{*}{$\begin{array}{l}\text { mSV } \\
\text { rem }\end{array}$} & \multicolumn{6}{|c|}{ Dose Rangs } & \multirow{2}{*}{ Total } \\
\hline & & $\begin{array}{l}0-10 \\
0-1\end{array}$ & $\begin{array}{c}10-20 \\
1-2\end{array}$ & $\begin{array}{c}20-30 \\
2-3\end{array}$ & $\begin{array}{c}30-40 \\
3-4\end{array}$ & $\begin{array}{c}40-50 \\
4-5\end{array}$ & $\begin{array}{r}50 \text { up } \\
5 \text { up }\end{array}$ & \\
\hline \multicolumn{2}{|c|}{ ORNL Employees } & 615 & $\because 1$ & 7 & 0 & 0 & n & 653 \\
\hline
\end{tabular}

Table 3.1.3 Average nose Per: Year of Employment ORNL -1980

\begin{tabular}{|c|c|c|c|c|c|c|c|c|}
\hline \multirow{2}{*}{ Group } & \multirow[b]{2}{*}{$\begin{array}{l}\text { mSV } \\
\text { rem }\end{array}$} & \multicolumn{6}{|c|}{ Dose Range } & \multirow{2}{*}{ Total } \\
\hline & & $\begin{array}{l}0-10 \\
0-1\end{array}$ & $\begin{array}{c}10-20 \\
1-2\end{array}$ & $\begin{array}{c}20-30 \\
2-3\end{array}$ & $\begin{array}{c}30-40 \\
3-4\end{array}$ & $\begin{array}{c}40-50 \\
4-5\end{array}$ & $\begin{array}{r}50 \text { up } \\
5 \text { up }\end{array}$ & \\
\hline \multicolumn{2}{|c|}{ ORNL Fmployees } & 563 & 80 & $\mathbf{5}$ & 5 & 0 & 0 & 653 \\
\hline
\end{tabular}


Table 3.1.4 Average of the Ten Highest Whole Body Doses and the Highest Individual Dose by Year

\begin{tabular}{lllll}
\hline Year & $\begin{array}{l}\text { Average of the } \\
\text { Ten Highest Doses } \\
\text { (ren) }\end{array}$ & $\begin{array}{l}\text { The Highest Dose } \\
\text { mS } \\
\text { itein) }\end{array}$ \\
\hline 1976 & 26.8 & 2.68 & 34.9 & 3.49 \\
1977 & 28.4 & 2.84 & 36.2 & 3.62 \\
1978 & 23.9 & 2.39 & 33.4 & 3.34 \\
1979 & 22.4 & 2.24 & 28.0 & 2.80 \\
1980 & 24.6 & 2.46 & 31.4 & 3.14 \\
\hline
\end{tabular}


Table 3.1.5 Personnel Meters Services

\begin{tabular}{rrrr}
1978 & 1979 & 1980 \\
\hline
\end{tabular}

A. Pocket Hexer Usage

1. Numbrs of Pairs Used

ORNL
CPF:*
Total

2. Average Nuber of Users

Per Quarter

ORNL

CPFF

Total

\begin{tabular}{rrr}
70,512 & 70,238 & 69,410 \\
20,748 & 8,022 & 5,026 \\
\hline 91,260 & 78,260 & 74,436
\end{tabular}

\begin{tabular}{rrr}
678 & 679 \\
-399 & 174 \\
\hline 1,077 & 853
\end{tabular}$-\frac{67 i}{109}$

B. Meters Processed for Monitoring Data

1. Beta-Gamma Badge-Meter

$30,630 \quad 30,520 \quad 15,260$

2. Neution Badge-Meter

\begin{tabular}{l|l}
710 & $800 \quad:, 030$
\end{tabular}

3. Hand Meter

$670 \quad 720 \quad 460$

"Cost Plus Fixed Fee Contractors - Rust Engineering. 
Table 3.1.6 Radiochemical Leb Analyses - 1980

\begin{tabular}{lrrrrr}
\hline Radionuclide & Urine & Seces & Milk & Water & Controls \\
\hline Plutonium, Alpha & 330 & 5 & -- & 52 & 89 \\
Transplutonium Alpha & 295 & 5 & -- & 52 & 61 \\
Uranium, Alfha & 269 & 3 & -- & - & 25 \\
Strontium, Beta & 245 & 11 & 420 & -- & 52 \\
Tritium & 169 & -- & -- & 120 & 10 \\
Todine-131 & -- & -- & 420 & -- & 52 \\
Othir & 19 & -- & -- & -- & -- \\
Totals & 1,327 & 24 & 8410 & 224 & 331 \\
& & & & & \\
\hline
\end{tabular}


Table 5.1.7 Counting Facilj ; halyses - 1980

\begin{tabular}{llll}
\hline Types of Samples & Number of Samples & Alpha & $\begin{array}{l}\text { Unit } \\
\text { Total }\end{array}$ \\
\cline { 2 - 4 } & & & \\
Facility Monitoring & & 23,016 & 45,017 \\
Smears & 21,991 & 28,694
\end{tabular}

Environs Monitoring

$\begin{array}{lrrc}\text { Air Filters } & 3,092 & 3,09 i & 6,184 \\ \text { Fallout } & & 2,990 & 2,990 \\ \text { Rainwater } & & 721 & 721 \\ \text { Surface Water } & & 321 & 3 z\end{array}$


Table 3.2.1 Portable Instruent Inventory - 1980

\begin{tabular}{lccc}
\hline Instrunent Type & $\begin{array}{c}\text { Instrunents } \\
\text { Added } \\
1980\end{array}$ & $\begin{array}{c}\text { Instruents } \\
\text { Retired } \\
1980\end{array}$ & $\begin{array}{c}\text { In } \\
\text { Service } \\
\text { Jan. 1, 1981 }\end{array}$ \\
\hline G-M Survey Meter & 11 & 9 & 311 \\
Cutie Pie & 7 & 16 & 309 \\
Alpha Survey Meter & 8 & 0 & 249 \\
Neutron Survey Meter & 0 & 0 & 101 \\
Miscel lantous & 0 & 0 & 5 \\
\multicolumn{1}{c}{ Total } & 26 & 25 & 979 \\
\hline
\end{tabular}

Table 3.2.2 Inventory of Facility Radiation Monitoring Instruments for the Year - 1980

\begin{tabular}{lccc}
$\begin{array}{c}\text { Instrument } \\
\text { Type }\end{array}$ & $\begin{array}{c}\text { Installed } \\
\text { During 1980 }\end{array}$ & $\begin{array}{c}\text { Retired } \\
\text { During 1980 }\end{array}$ & $\begin{array}{c}\text { Total } \\
\text { Jan. 1, 1981 }\end{array}$ \\
\hline Air Monitor, Alpha & 3 & 0 & 110 \\
Air Monitor, Beta & $n$ & 2 & 161 \\
Lab Monitor, Alpha & 6 & 2 & 184 \\
Lab Monitor, Beta & 6 & 1 & 228 \\
Monitron & 9 & 9 & 203 \\
Other & 1 & 0 & 146 \\
Total & 25 & 14 & 1,032 \\
\hline
\end{tabular}


Table 3.2.3 Heasth Physics Facility Monitoring Instruments DLvisional Allocation - 1980

\begin{tabular}{|c|c|c|c|c|c|c|c|}
\hline ORNL Division & $\begin{array}{l}\alpha \text { Air } \\
\text { Monitor }\end{array}$ & $\begin{array}{l}\text { B Air } \\
\text { Monitor }\end{array}$ & $\begin{array}{l}\text { a Lah } \\
\text { Monitor }\end{array}$ & $\begin{array}{l}\text { B Lab } \\
\text { Monitor }\end{array}$ & Monitron & Other & Total \\
\hline Analytical Chemistry & 8 & 10 & 16 & 19 & 14 & 4 & 71 \\
\hline Chemical Technology & 52 & 39 & 77 & 48 & 41 & 35 & 292 \\
\hline Chemistry & 7 & 1 & 13 & 14 & 2 & 4 & $4 l$ \\
\hline Metals and Ceramics & 15 & 15 & 2 & 12 & 8 & 17 & 89 \\
\hline Operations & 15 & 84 & 39 & 89 & 110 & 46 & 383 \\
\hline All Others & 13 & 12 & 17 & 46 & 28 & 40 & 156 \\
\hline TOTAL. & 110 & 161 & 184 & 228 & 203 & 146 & 1,032 \\
\hline
\end{tabular}


Table 3.2.4 Calibrations Facility Resume - 1980

\begin{tabular}{cc}
\hline Item & Number of Calibrations \\
\hline Beta-Gamma Survey Meters & 2,361 \\
Neutron Survey Meters & 358 \\
Alpha Survey Meters & 877 \\
Personal Dosimeters & 3,745 \\
Badge Dosimetry Components & 1,420 \\
\hline
\end{tabular}




\subsection{ENVIRONENTAL MANAGEMENT FROGRAM}

During CY 1980 the Enviromental Managenent Progran consisted of the Office of Eivironmental Coordinator and the Department of Environmental Management.

\subsection{Department of Enviromental Mar igement}

The Department of Enviromental Managament of the Industrial Safery and Applied Health Physics Division monitors for airborne radioactivity in the East Tennessee area using three separate monitoring networks. The local air monitoring (LAM) network consists of 23 stations that are positioned relatively close to ORNL operatisnal activities; the perimeter air monitoring (PAM) networh consists of nine stations located on the perimeter of the DOE-controlled area and provides data for evaluating the impact of all Oak Ridge operations on the imaediate environment; and the remote air monitoring (RAM) network consists of seven stations located outside the DOE-controlled area at distances of 19 to $121 \mathrm{~km}$ (12 to $75 \mathrm{miles)}$ from ORNL (see Figs. 4.1.1-4.1.4). The nonitoring networks provide for the collection of (1) airborne radioaztivity by air filtration techniques, (2) radioparticulate fallout material by impingement on gummed paper trays, (3) rainwater for measurement of fallout occurring as rainout, (4) radioiodine using charcoal cartridges, and (5) tritium using silica gel (selected LAMs).

Low-level radioactive liquid wastes originating from ORNL operations are discharged, after treatment, to White Oak Creek, which is a small tributary of the $\mathrm{Cl}$ inch River. The radioactive content of white Oak Creek discharge is determined at white Oak Dam, which is the last control point along the stream prior to the entry of White Oak Creek into the Clinch River. Water samples are also collected at several locations in the Clinch River, beginning at a point above the entry of the wastes into the river and ending at Kingston Water Plant near Kingston, Tennessee, the nearest population center downstream (Fig. 4.1.5).

Samples of White Oak Creek effluent are collected at White Oak Dam by a contisuous profortional sampler and analyzed weekly for gross beta, gross alpha, ${ }^{3} \mathrm{H},{ }^{60} \mathrm{Co},{ }^{90} \mathrm{Sr},{ }^{106} \mathrm{Ru},{ }^{137} \mathrm{Cs}, \mathrm{f}$ lutonium, and transplutonici elements. Calculations are made of the consentrations of radioactivity in the Clinch River at the point of entry of White Oak Creek (Clincin River Mile [CRM] 20.8), using the concentrations measured at white Oak Dam and the dilution provided by the river. To verify the calculated concentrations, two sampling stations are maintained in the Clinch River below the point of entry of the wastes; one at the Oak Ridge Gaseous Diffusion Plant (ORGDP) water intake (CRM 14.5) and the other at Kingston Water Plant llear Kingston, Tennessee (TRM 568, near C.PM 0.0 ). An additional sampling station is maintained in the Clsnch River at Melton 
Hill Dan (CPM 23.1) aboye the pcint of entry of the waste to provide baseline data and at the wouth of thite Oak Creek for backup neasurements of Mhitc Oak Dan station.

The ORGDP water sappling station collects a saple from the Clinch River proportional to the flow in the river near the water intake of the GRGDP water system. The samples are brought into the Laboratory at weekly intervals, and an aliquot is composited for quarterly analysis of tritiun. The remaining portion of the saple is passed over anion and cation resins to reave nuclides. At quarterly intervals, the resin colums are eluted, and the eluate is analyzed for gross activity and for individual radionuzlides that may be present in significant anounts.

A "grab" sample is collected daily at the Kingston vater Plant sampling station which is located near the mouth of the Clinch River at TRM 568. The daily grai samples are composited and analyzed on a quarterly basis. The preparation of these samples and the enalyses perforned are the sare as those for the ORGDP water sampling station.

The Melton Hill Das sapling station collects a saple proportional to the flow of water through the power-generating turbines, which represents all oi the discharge from the Dan other than a minor anount discharged in the operation of the locks. Sanples are collected from the station at weekly intervals, processed, and analyzed in the sase manner as for the CRGDP water sampling station.

Samples of ORNL's potable water are collected daily, composited, and stored. At the end of each quarter, these comosites are analyzed radiochenically for ${ }^{96} \mathrm{Sr}$ content and are assayed for long-lived gamaeaitting radionuclides by gama spectrometry.

Raw milk is collected at 12 sampling stations located within a radius of 50 miles from ORNL. Samples are taken on a veekly basis from seven stations located outside the DOE-controlled area within a 20-mile radius of ORNL (Fig. 4.1.6). Samples are collected every five weeks from the five remaining stations located more zemotely with respect to Oak Ridge operations out to distances of about 50 miles (Fig. 4.1.7). The purpose of the ailk sampling program is twofold: first, samples collected in the immediate vicinity of ORNL provide data by which one may evaluate the possible effect of effluer:ts from ORNL operations; second, samples collected remote to the imediate vicinity of ORNL provide background data wich are essential in establishing a proper index from which releases of radioactive materials originating from oak Ridge operations may be evaluated. The milk samples are analyzed by radiochemical techniques for strontium-90 and iodine-131. The minimum detectable concentrations of strontium-90 and iodine-131 in wilk are $18.5 \mathrm{mBq} / \ell(0.5 \mathrm{pC} i / \ell)$ and $16.7 \mathrm{mBq} / \mathrm{l}(0.45 \mathrm{pCi} / \ell)$, respectively. 
External gama radiation background weasurenents are made routinely at $t$.e local and perineter air zonitoring stations, at one stition located near Melton Hill Dae and at the remote =onitoring stations; measurements are made using calcium fluoride thermoluninescent dosineters suspended one neter above the ground. Dosineters at the perimeter stations and Melton Hill Dan are collected and analyzed nonthly. Those at local and resote station; are collected and analyzed semianmua!ly.

External gana radiation neasurements are also made routinely along the bank of the Clinch River from the wouth of White Oak Creek to points several hundred yards domstrean (Fig. 4.1.8). These measurements were used to eva?uate gana radiation levels resulting from ORNL liquid effluent releases and "sky shine" from an experimental ${ }^{137} \mathrm{Cs}$ plot located near the rive: bank. Radiation measurenents were made using lithiu fluoride thermoluminescent dosimeters suspended one meter above the ground surface.

Various species of fish, which are comonly caught and eaten in eastern Tennessee, are taken from the Clinch River quarterly from CRM 20.8 (intersection of thite Oak Creek and the Clinch River) and annually from other locations in the Clinch River. Ten fish of each species are compsited for each sample; and the samples are analyzed by gana spectrometric and radiochemical techniques for the critical radionuclides, which nay contribute significantly to the potential radiation dose to man.

Soil and grass samples 3re collected semiannually and annually, resfectively, from locations near the PAM and RAM stations. Ten samples, approxinately $8 \mathrm{~cm}$ in dianeter and $5 \mathrm{~cm}$ thick, are collected from five $400-\mathrm{cm}^{2}$ flots at each location, composited, and analyzed by gama spectroscopy, and radiochemical techniques for uranium, plutonium, and various other radioisotopes.

\subsection{Office of Environnentai Coordinator}

The major functions of the Office during 1980 were:

1. Coordinated the Laboratory's pollution abatement and monitoring programs.

2. Served as liaison between the various ORNL groups involved in pollution control, ORNil management and UCC-ND Office of Safety and Environmental Protection.

3. Determined the pollutants (radioactive and nonradioactive) to be monitored in effluents and environmental media and the location and frequency of the measurements.

4. Identified areas where development rork, additional monitoring equipment, and changes in waste disposal practices are required fcr pollution abatement. 
5. Maintained adequate records on significant effluents within the ir:stallation

6. Reviewed, or provided for review, the design, acquisition, and installation of required pollution contrul equipment.

7. Prepared environmental assesspents for tiose Laboratory construction projects which require them.

8. Prepared monthly, quarterly, and annual reports on radioactive and nonradioactive effluents as required by UCC-ND managenent and the DOE.

9. Reviewed Laboratory construction projects for enviromental inpact.

\subsection{Atmospheric Monitoring}

\subsubsection{Air Concentrations}

The average concentrations of alpha radioactivity in the atmo:phere, as measured with filters from the LAM, FAM, and RAM networks during 1980, were as follows:

$\begin{array}{ll}\text { Network } & \text { Concentration } \mathrm{Bq} / \mathrm{m}^{3}(\mathrm{NC} \\ \text { LAM } & 0.72 \mathrm{E}-04(0.15 \mathrm{E}-14) \\ \text { PAM } & 0.36 \mathrm{E}-04(0.97 \mathrm{E}-15) \\ \text { RAM } & 0.42 \mathrm{E}-04(0.11 \mathrm{E}-14)\end{array}$

All networks are less than $10 \%$ of $0.74 \mathrm{E}-03 \mathrm{~Bq} / \mathrm{m}^{3}\left(2 \times 10^{-1}+\mu \mathrm{Ci} / \mathrm{cc}\right)$, the MPCU ${ }^{1}$ for a low level unidentified alpha emission in an uncontrolled area. The values for each station are given in Table 4.3.1.

The average concentrations of beta radioactivity in the atmosphere, as measured with filters from the LAM, PAY, and RAM networks during 1980, were as follows:

$\begin{array}{ll}\text { Network } & \text { Concentration } B o / m^{3}(u C \\ \text { LAM } & 0.19 \mathrm{E}-02(0.52 \mathrm{E}-13) \\ \text { PAM } & 0.11 \mathrm{E}-02(0.29 \mathrm{E}-13) \\ \text { RAM } & 0.11 \mathrm{E}-02(0.29 \mathrm{E}-13)\end{array}$

\footnotetext{
${ }^{1}$ The MPCU is defined as the maximun permissible concentration for an unknown totixture of radioisotopes in air. DOE Manual Chapter 0524, Appendix, Annex A, gives exposure values applicable to various mixtures of radionuclides and establishes guidelines for deriving the $\mathrm{MPCU}_{\mathrm{a}}$.
} 
The LAM network value of $0.19 \mathrm{E}-02 \mathrm{~Bq} / \mathrm{m}^{3}(0.52 \mathrm{E}-13 \mu \mathrm{Ci} / \mathrm{cc})$ is less than $0.062 \%$ of the MPCU based on occupational exposure of $1.1 \mathrm{E}+02$ $\mathrm{Bq} / \mathrm{m}^{3}\left(3 \times 10^{-9} \mu \mathrm{Ci} / \mathrm{Cc}\right)$. Both the PAM and RAM network values represent $<0.03 \%$ of the MPCU of $3.7 \mathrm{~Bq} / \mathrm{m}^{3}\left(1 \times 10^{-10} \mathrm{\mu Ci} / \mathrm{cc}\right)$ applicable to releases to uncontrôlled areas. A tabulation of data for eact station in each network is given in Table 4.3.2. The weekly values for each network are illustrated in Table 4.3.3.

\subsubsection{Fallout (Gummed Paper تiechnique)}

The average activity per square foot on gunmed paper for the three air monitoring networks is shown in Table 4.3.4.

\subsubsection{Rai..ovt (Gross Anaijsis of Rainwater)}

The average concentration of beta radioactivity in rain water collected from the three networks during 1980 was as follows:

$\begin{array}{ll}\text { Network } & \text { Concentration } \mathrm{Bq} / \mathrm{m}^{3}(\mu \mathrm{Ci} / \mathrm{m} \ell) \\ \text { LAM } & 0.82 \mathrm{E}+03(0.22 \mathrm{E}-07) \\ \text { PAM } & 0.73 \mathrm{E}+03(0.20 \mathrm{E}-07) \\ \text { RAM } & 0.11 \mathrm{E}+04(0.29 \mathrm{E}-07)\end{array}$

The average concentratio: measured at each station within each network is presented in Table 4.3.5. The average concentration for each network for each week is given in Table 4.3.6.

\subsubsection{Atmospheric Radioiodine (Charcoal Cartridge Technique)}

Atrospheric iodine sampled at the perimeter stations averaged $0.50 \mathrm{E}-04 \mathrm{~Bq} / \mathrm{m}^{3}(0.13 \mathrm{E}-14 \mu \mathrm{Ci} / \mathrm{\prime}=)$ during 1980 . This average represents $<0.005 \%$ of the maximum permissible concentration of $3.7 \mathrm{~Bq} / \mathrm{m}^{3}$ $\left(1 \times 10^{-10} \mu \mathrm{Ci} / \mathrm{cc}\right)$ applicable to inhalation of $131 \mathrm{I}$ released to uncontrolled areas. The maximum concentration observed for one week was $0.74 \mathrm{E}-04 \mathrm{~Bq} / \mathrm{m}^{3}(0.20 \mathrm{E}-1+\mu \mathrm{Ci} / \mathrm{cc})$.

The average radioiodine concentration at the local stations was $0.13 \mathrm{E}-03 \mathrm{~Bq} / \mathrm{m}^{3}(0.34 \mathrm{E}-14 \mu \mathrm{Ci} / \mathrm{cc})$. This concentration is $<0.001 \%$ of the maximum permissible concentration for inhalation by occupational personne1. The maximum concentration for one week was $0.43 \mathrm{E}-03 \mathrm{~Bq} / \mathrm{m}^{3}$ $(1.1 \mathrm{E}-13 \mu \mathrm{Ci} / \mathrm{cc})$.

Table 4.3.7 presents the ${ }^{131}$ I weekly average concentration data for both the local area and the perimeter area air monitoring networks. The weekly average ${ }^{131} \mathrm{I}$ concentration in air measired by stations in the LAM and PAM networks are given in Table 4.3.8.'

The rusults of the specific radionuclide analyses of the filters from the three networks are given in Table 4.3.9. 


\subsubsection{Nonradioactive Air Particulates}

Environmental air sampling for nonradioactive air particulates has recently been initiated at Oak Ridge National Laboratory due to the conversion of the steam plant from gas to coal burning.

Suspended particulates are measured at air monitoring stations 1 , $3,6,7$, and 15 (Fig. 4.1.1). The method for the determination of suspended particulates is the high volume method recommended by EPA.

Particulates are collected by drawing air through weighed filter papers. The filter paper is allowed to equilibrate in a humidity-controlled atmosphere and the filter is reweighed. From the weight of particulates, the sampling time, and the air fiow rate, the particulate concentration in micrograms per cubic meter is calculated. The sampling period i= 24 hours. Air monitoring data for suspended particulates are presented in Table 4.3.10. All samples taken had values below the allowable standards.

\subsubsection{Milk Analysis}

The yearly average and maximum concentrations of ${ }^{90} \mathrm{Sr}$ and ${ }^{131} \mathrm{I}$ in raw milk are given in Tables 4.3.11 and 4.3.12. If one assumes the average intake of milk per individual to be one $\ell /$ day, the concentrations of ${ }^{131} \mathrm{I}$ in milk collectrd near ORNL and in milk collected more remotely from ORNL are within FRC Range $1 .{ }^{2}$ The concentrations of ${ }^{90} \mathrm{~S}_{i}$ in milk from both ti:s imnediate and remote environs of ORNL are also within FRC Range I.

\subsubsection{ORNL Stack Releases}

The radionuclide releases from ORNL stacks are summarized in Table 4.3 .13 .

\subsection{Water Monitoring}

\subsubsection{White Oak Lake Waters}

Yearly discharges of specific radionuclides to the $\mathrm{Cl}$ inch River, 1968 through 1980, are shown in Table 4.4.1.

Values for radionuclide concentrations at various locations in the C1inch River are given in Table 4.4.2. The calculated percentages of maximum permissible concentration values in water $\left(\mathrm{MPC}_{w}\right)$ are presented in Table 4.4.3.

\footnotetext{
2The Federil Radiation Council ranges are still accepted values even though the FRC has been incorporated into the EPA.
} 
The annual average percent MPC of beta emitters, other than tritium in the Clinch River, 1968 through 1980, is given in Table 4.4.4. Table 4.4.5 lists the annual average percent MPC of tritium in the Clinch River, 1968 through 1980.

Trends in radionuclide discharges and MPC levels are presented in -igs. 4.4.1 through 4.4.3. Discharges of ${ }^{3} \mathrm{H}$ andd ${ }^{90} \mathrm{Sr}$ are shown in Fig. 4.4 .1 as these nuclides contribute the majority of the radiological dose downstrean.

Water sampi as are collected for the analysis of nonradinactive substances at the same locations discussed previously under ra.lioactive water simpling. Ali samples are composited for monthly analyse.s.

Samples are analyzed for a variety of water quality parameters related to process release potential and background information needs by analytical procedures recomended by the Environmental Protection Ageiscy.

Data on chemical ( uncentrations in surface streams are given in Tables 4.4.6, and 4.4.7. The average concentrations of all substances a:jaly Led were in compliance with Tennessee guideiines. The National Pollutant Discharge Elimination Syztem compliance on water quality is presented in Table 4.4.8.

\subsubsection{Putabie Water}

The average yuarterly concentrations of ${ }^{90} \mathrm{Sr}$ in potabie water at ORNL during 1980 were as follows:

$\begin{array}{ccc}\text { Quarter Number } & \underline{B q} / \varepsilon & \underline{\mu C i / m \ell} \\ 1 & 8.5 E-3 & 0.23 E-9 \\ \dot{3} & 6.7 \mathrm{E}-3 & 0.18 \mathrm{E}-9 \\ 4 & 1.9 \mathrm{E}-3 & 0.05 \mathrm{E}-9 \\ \text { Average for Year } & 83 \mathrm{E}-3 & 2.27 \mathrm{E}-9 \\ & 25 \mathrm{E}-3 & 0.68 \mathrm{E}-9\end{array}$

The average value of $2.5 \times 10^{-2} \mathrm{~Bq} / \ell\left(68.0 \times 10^{-11} \mu \mathrm{Ci} / \mathrm{ml}\right)$ represents $<0.2 \%$ of the $M P C_{w}$ for drinking water applicable to individuals in the general population."

\subsubsection{Clinch River Fish}

The results of the analyses (f fish samples are tabulated in $B q / k g$ and $(\mathrm{pCi} / \mathrm{kg}$ ) of wet weight (Table 4.4.9) for each radionuclide of significance. An estimate of man's intake of radionuclides from eating the fish is made by assuming an annuai rate of fish consumption of $16.8 \mathrm{~kg}$ (37 ibs). An estinlated percentage of maximum permissible intake is calculated by assiming a maximum permissible intake of fish to be comrarable to a daily intake of 2.2 liters of water containing the MPC of these radionuclides for a period of one year. Mercury concentrations were compared to the FDA proposed action le'el. 


\subsection{Radiation Background Measurements}

Data on the average external gamma radiation background rates ar: biven in Tables 4.5.1 and 4.5.2. The difference between the average leve's in the perinnter and remote environs is considered to be within the variation in backsr sund levels normally experienced in East Tennessee which is dependent upon elevation, topography, and geological character of surrounding soil. ${ }^{3}$

The average external gamma radiation levels along the bani of the Clinch River adjacent to an experimental cesium field are biven in Tahle 4.5.3.

\subsection{Soil and Grass Samples}

Data on uranium, plutonium, ind other radioisotope concentrations in soil and grass samples are given in Tables 4.6.1 and 4.6.2.

\subsection{Deer Samples}

Occasionally, deer are killed by automobiles on the DUE Reservation. Nineteen road-killed deer were analyzed during 1980 for gamma emitters and the data is presented in Table 4.7.1. it should be noted that hunting is illegal on the Gak Ridge Reservation.

\subsection{Calculation of Potential Radiation Dose to the Public}

Potential radiation doses resulting from plant effluents were calculated for a number of dose reference points within the Oak Ridge environs. Ali significant sources and modes of exposure were examined, and a number of general assumptions were used in making the calculations.

The site boundary for the Oak Ridge complex was defined as the perimeter of the DOE-controlled area.

Gaseour effluents are discharged from several locations within ORNL. For calculational purposes, the gaseous discharges are assumed to occur from only one vent. Concentrations of rar'ionuclides contained in the air anil deposited on the ground were estimated at distances up to 50 miles from the Oak Ridge acilitics with the Gaussian plume model developed by Pasquili $i^{4}$ and $G$ ifford ${ }^{5}$ incorporates in a computer program. The concentration has been averaged over the crosswind direction to give.

${ }^{3}$ T. W. Oakes, K. E. Shank, and C. F. Easterly, "Natural and Man-Made Radionuclide Concentrations in Tennessec Soil," in Proceedings of the Health Physics Society Tenth Midyear lopical Symposium, Saratoga Springe, New York, October 1-13, 1976, TF. 322-333.

${ }^{4} \mathrm{~F}$. Pasquiil, Atmospheric Diffusion, D. Van Nostrand Co., Ltd., London, 1262 .

SF. A. Gifford, Jr., The Problem of Forecasting Dispersion in the Lower Atmosphere, USAEC, DTi, 1962. 
the estinated ground level concentration downwind of the source of enission. The deposition velocities used in the calculations were $10^{-6} \mathrm{cn} / \mathrm{sec}$ for kxypton and xenon, $10^{-2} \mathrm{~cm} / \mathrm{sec}$ for iodine and $1 \mathrm{~cm} / \mathrm{sec}$ for particulates. Meteorological data is shown in Fig. 4.8.1; the length of the bars indicates the percentage of the time that wind is blowing in that direction. Populations used are shown in Table 4.8.1.

Exposures to radionuclides that originate in the efflueits released from the Oak Ridge facilities were converted to estinates of radiation dose to individusls using models and data presented in publications of the International Comission on Radiological Protection, other recognized literature on radiation protection, personal comunication, and computer prograns incorporating soze of these models and data. Radioactive material taken into the body iy inhalation or ingestion will contimuously irradiate the idy until renoved by processes of metabolisa and radioactive decay; thus the estimates for internal dose are called "dose conitnents"; they are obtained by integration over an assuned working lifetine of 50 years for the exposed individual.

The radiation doses tc the total body and to internal organs from external exposures to penetrating radiation are approximately equal, but they may vary considerably for internal exposures because some radionuclides concentrate in certain organs of tire body. For this reason, estinates of radiation dose to the total body, thyroid, lungs, bone, liver, kidneys, and gastruintestinal tract were considered for various pathways of exposure. These estimates were based on parameters applicable to an average adult. The population dose estimate (in man-rem) is the sum of the total body doses to exposed individuals within a 5C-mile radius of the Oak Ridge facilities.

Maximan Potential Exposure - The point of maximum potential exposure "fence-post" dose) on the site boundary is located alcng the bank of the Clinch River adjacent to a cesium field experimental plot and is due prinarily to "sky shine" from the plot. A maximum potential whole body duse of $2.3 \mathrm{mSv} / \mathrm{y}$ (226 mrem/y) was calculated for this location assuning that all individual remained at this point for $24 \mathrm{~h} /$ day for the entire year. The calculated maximum potential exposure is $45 \%$ of the allowable standard. 6 This is an atypical exposure location and the probability of an exposure of the magnitude calculated is considered reate since access is only by boat.

The total body dose to a "hypothetical maximun exposed individual" at the same location was calculated using a more realistic residence time of $240 \mathrm{~h} / \mathrm{y}$. The calcuiated dose under these conditions was $0.06 \mathrm{mv} / \mathrm{y}^{-}(6.6 \mathrm{mrem} / \mathrm{y})$ wich is 1.28 of the allowable standard and represents at is considered a probable upper limit of exposure.

${ }^{6}$ DOE Manual Chapter 0524. 
A moxe probable exposure potential might be considered to occur at other locations beyond the site boundary as a resulx of airborne or liquid effluent releases.

The dose comitment to an individual continuously occupying the residence nearest the site boundary would result from inhalation and ingestion and is bajed on an inhalation rate for the average dult of $2 \times 10^{4} \mathrm{l} / \mathrm{day}$. The calculated dose comitments at this location vere $0.17 \mathrm{mSv}$ (16.6 mrem) \pm 300 to the lung (the critical organ) and 0.02 uSv $(1.8 \mathrm{mrem})$ i 30c\% to the total body; cranium-23t is the important radionuclide contributing to this dose. These levels are 1.17 and 0.367 respectively, of the allowable annual standard. The large error bounds are due to the uncertainties in the meterclogical and source-term data.

The most important contribution to dose from radioactivity within the food-chain is by tha atmosphere-pasture-cow-milk food-chain pathway. Measurements of the two principal radionuclides entering into this pathway, ${ }^{131} \mathrm{I}$ and ${ }^{90} \mathrm{Sr}$ (see Tables 4.3 .11 and 4.3.12), indicates that the maximun dose to an individual in the iamediate environs from ingestion of $1 \mathrm{l} /$ day of milk is $0.0002 \mathrm{mSv}(0.02 \mathrm{mrem})$ to the thyroid and $0.02 \mathrm{mSv}$ (1.5 mrem) to the bone at Statior. 6 (sce F $=g .4 .1 .6$ ). The average concentrations for the remote stations were assumed to be background and were subtracted from the perimeter station data in making the calculations.

The public water supply closest to the liquid discharges from the Oak Ridge facilities is located approximately $26 \mathrm{~km}$ (16 miles) downstrean at Kingston, Tennessee.

Measurements of untreated river water samples at Kingston (see Table 4.4.2) indicate that the maximum dose comitment resulting from the ingestion of $20 \%$ of the daily adult requirement (aboitt $2 \mathrm{l} /$ day) is $0.07 \mathrm{mSv}$ ( $6.6 \mathrm{mrem}$ ) to the bone, and $0.02 \mathrm{mSv}(1.5 \mathrm{mrem})$ to the whole body. The average concentrations for Melton Hill water (background) were subtracted from the values obtained at Kingston.

Estimates of the 50-year dose commitment to an adult were calculated for consumption of $16.8 \mathrm{~kg}$ ( $37 \mathrm{lbs}$ ) of fish per year from the Clinch River. The consumption of $16.8 \mathrm{~kg}$ ( $37 \mathrm{lbs}$ ) is about 2.5 times the national average fish consumption and is used because of the popularity of fishing in East Tennessee. From the analysis of edible parts of the fish examined (see Table 4.4.9), the maximum organ dose commitment to an individual from the bluegill samples taken from CRM 20.8 is estimated $=0$ be $0.72 \mathrm{mSv}(72 \mathrm{mrem})$ to the bone from ${ }^{90} \mathrm{Sr}$. The maximum total body dose to an individual was calculated to be $0.014 \mathrm{mSv}$ (1.4 mrem). These doses are $5 \%$ and $0.3 \%$ respectively, of the allowable standard. Fish samples taken from above White Oak Creek were analyzed to determine background conditions. 
Sumaries are given in Table 4.8 .2 of the potential radiation doses to adult m:ivers of the general public at the points of highest potential exposure from gaseous ind liquid effluents from the Oak Ridge saciiities.

Dose to the Population - The Oak Ridge population received the largest average individual total body dose as a population group. ine average yearly total body dose to an Oak Ridge resident was estimated to be $0.0011 \mathrm{mSv}(0.11 \mathrm{mrem})$ as compared to approximately $1 \mathrm{mSv}$ (100 mrem) from natural background radiation; the average dose comitment to the lung of an Oak Ridge resident was $0.112 \mathrm{mSv}(1.2 \mathrm{mrem})$. The maximu potential dose commitment to an Oak Ridge resident was calculated to be $0.17 \mathrm{mSv}$ (16.6 mrem) to the iung. This calculated dose is 0.36 of the allowable aniual standard.

The cumulative total body dose to the populatior within a 50-mile radius of the Oak Ridge facili:ies resulting from 1980 plant effluents was calculated to be 0.09 man-mSv $(8.8$ man-: $=m)$. This dose may be compared to an estimated 74,000 ian-rem to the same population resulting from natural background radiation. About $14 \%$ of the collective dose from the effluents of the Oak Ridge facilities is estimated to be to the Oak Ridge population.

\subsection{Environmental Monitoring Samples}

A listing of environmental mon:toring samples processed by type, sample, type of analyses, and number of samples is given in Table 4.9.1.

4.10 Highlight: or Other Major Activities of the Environmental Management Program

4.10.1 Environmental Protection Awards

An Environmental Protection Award has been inititated by the Department of Environmental Management to be presented annually. The award is presented to an individual or group for outstanding contributions to the environmental protection program. A selection comittee will judge the applicants based on the following points: (a) scientific and technical merit of the achievement; (b) potential cost savings for the Laboratory; and (c) innovation.

\subsubsection{Waste Oil Investigation Comnittee}

Repeated occurrences of improper discharges of oil at ORNL resulted in the formation of the ORNL Waste Oil Investigation Comnitree on March 14, 1979. The Comnittee has completed its investigation asid a report is in progress. 


\subsubsection{ORNi Comittee of Meteorological Data Users}

In August 1980, a comittee was established to ensure the naximun use of existing and new meteorolcgical data. This Comittee has three functions: (1) to review the availability of existing data; (2) to review the capabilities of the three proposed neteorological towers (a 1981 GPP project) to ensure that the maximun amount of data is collected; and (3) to review the format of the data to be collected to ensure that it is compatible with cxisting progran needs.

There are nine regular nembers of the Comittee. ORr: has seven members representing ix divisions: Industrial Safety and Applied Health Yhysics Division - T. W. Oakes, Chairman, and B. A. Kelly, Secretary; Energy Division - F. C. Kornegay; Environnental Sciences Division - R. J. Luxwore; Health and Safety Research Division - C. W. Miller; Computer Sciences Division - R. J. Raridon; and Fuel Recycle Division - M. B. Sears. In addition, a representative of MOM's Atmospheric Tubulence Diffusion Labsratory (D. Matt) and a consultant from the University of Tennessee's Department of Civil Engineering (E. S. Hougland) participated in the Comittee's work. Representatives from Y-12 and ORGDP also participated to ensure that ORNL's meteorologinal data collection system is compatible with theirs.

\subsubsection{Resource Conservation and Recovery Act (RCRA) - State and Federal Permits}

In May 1980, the Enviromental Protection Agency, as required by RCRA of 1976, tock steps to establish a national hazardous waste management system. Prior to the compliance date of these regulations, November 19, 1980, ORNL was requried to notify EPA of its hazardous waste activities. During 1980 several lengthy pernit applications and supporting documents dealing witi hazardous waste management at ORNL were prepared by this Department to satisfy federal and state requirements. Presently the Laboratory is licensed, on an interim status permit, as a generator, storage facility, transporter, and treatment facility of hazardous wastes.

\subsubsection{Hazardous Waste Analysis Laboratory}

Presently there are over 400 hazardous chemicals/wastes, ei ther from specific sources or as discarded hazardous chemicals listed by the Environme!ta: Protection Agency under the Resource Conservation and Recovery Act. Many waste streams are generated at ORNL for which the hazardous nature is not known. For these types of wastes, EPA regulations currently require testing of specific parameters e.g.', ignitability, corrosivity, reactivity, and toxicity, to deterwine if a waste mus: be treated as a hazardous waste.

10 accomplish this mission, a Hazardous Waste Analysis Laboratory has been established. To date, approximately fifty ignitability tests have been performed and toxicity measurements have recentiy comenced. 
4.10.6 Polychlorinated Biphenyl (PCB) Sampling Program

In June 1980, the Department of Energy requested that all sources of oil at their facilities be checked for the presence of PCB's. The Department of Environmental Management took samples from 1,802 such sources. Analytical results showed that 233 of the samples contained PCB's in concentrations greater than five parts per million. Plans are now underway to latel the sources containing PCB's and to replace this oil with new oil.

\subsubsection{Cheaical Waste Disposal at ORNL}

During 1980, approximately 390 disposal requests were handled by the Hazardous Materials Group of the Department of Environmental Management. These disposal requests represent over $110,000 \mathrm{~kg}(242,000 \mathrm{lbs})$ of hazardous and non-hazardous wastes generated zt the Laboratory. By utilizing approved off-site comerical facilities for disposal, the Laboratory was able to comply with existing regulations. Also, there was approximately $6,800 \mathrm{~kg}(14,960 \mathrm{lbs})$ of non-contaninated waste oils recycled for further use.

\subsubsection{Soil Contamination Analyses}

The DEM provided assistance to the Engineering Division in evaluating contamination levels near proposed construction sites. Ten cores were analyzed and the results sent to Engineering for evaluation.

\subsubsection{Prototype Air Monitoring Station}

The DEM, in conjunction with the Instrumentation and Controls and Computer Sciences Divisions, has developed a prototypic replacement for the air monitors in its environmental monitoring network. The prototype was designed to emphasize the needs of real-time analytical capability, maintainability, and flexibility for monitoring additional parameters in the future. Parameters monitored continuously include gross beta/gama radioactivity (using a GM counter), gamma-emi.cing radionuclides (using a GE(Li) spectroneter system), alpha fallout radioactivity, beta/gana fallout radioactivity, and rainfall. In addition, sampling is performed for particulates, radioiodine, fallout (wet and dry), and tritium. The readings for monitored variables nc wilected by a station microprocessor, which stores them (up to 24 hours), checks them against alarm setpoints, and transmits them upon request to a centralized readout station. The station microprocessor also checks the instruments to ensure proper operation and sends an alarm signal if a malfunction is detected. The centralized readout station is a minicomputer-controlled terminal, based on a Nuclear Data 680 system. The terminal provides a digital display of the monitoring data, stores the data on a floppy disc, and displays alarms. Analytical and other programs can also be run on the system. The system is currently undergoing operational check-out. 


\subsubsection{Clark Center Recreational Park (CCRP) Irinking Nater Syster Inprovenents}

The DEM coordinated the design, construction, check-out, and operational monitoring of two new drinking water systems at CCRP. The new systems received approval from the State of Tennessee and operated for the majority of the 1980 park season.

\subsubsection{ORNL Stean Plant Stack Testing}

In August 1980, the DEM coordinated the testing of one of four new electrostatic precipitators at ORNL's Stean Plant. The results of this test, along with evaluations perforned by the DEI and its consultants, were used to ensure proper performance of the Stean Plant when it is burning coal.

\subsubsection{Enviromental Assessments}

Nineteen enviromental assessments were copleted during 1980 . The projects for which enviromental assessments were witten are:

- Improvements to Fusion Energy Facilities

- Water Pollution Control

- Enviransental and Effluent Monitoring Systems Upgrading

- Laboratory Emergency Response Center

- Modifications Aimed at Compliance with CSHA

- Low Level Waste Pilot Facility

- Cytological Laboratory

- Toxic Substances Laboratory and Animal Facility

- Mutagenic Screening and Testing Facility for Synthetic Fuels

- High Temperature Materials Laboratory

- Accelerator and Reactor I urovewent Project

- Materials Warehouse Upgrading

- Large Coil Test Facility

- Energy Systems Research Laboratory

- Core flow Test Loop Facility

- Utilities Upgrade Project

- Meteorological Towers - ORNL

- Elmo Bumpy Torus - Proof of Principle Experinent

- ORNL Visitor OVerlook.

\subsubsection{New and Improved Facilities}

The DEM initiated work on three projects wich are still ongoing: (1) the installation of two plastic tanks in the 7000 area to store spent photographic processing solutions; (2) the installation of a continuous residual chlorine analyzer at ORNL's Sewage Treatment Plant; and (3) the design and constuction of a treatment system for Cosl Yard kunoff. Work also continued on two proposed line item projects: Water Pollution Control and Environsental and Effluent Monitoring Systems Replacement. 


\subsection{It Computeized Data Processing}

An effort is underway to computerize, as much as is practicable, the storage, manipulation and reporting of environmental data. Revised programs include the ones for processing of milk, air and water data. New programs have been developed for reporting air and milk data in a ready-for-publication formit. Programs for processing National Pollutant Discharge Eliminatior System (NPDES) data are scheduled to be completed by 1981 .

\subsubsection{Ha-ardous Materials Tracking System}

The Department, in cooperation with Computer Sciences Division personne1, has been developing a Hazardous Materials Tracking System (HTS) designed to track hazardous materials at ORNL from the time they are received or generated through their usage and storage in the Laboratory, up until their final disposal (cradle-to-grave).

At the present time, an information file containing pertinent data on over 1,700 chemicals is on line and is available to Laboratory personnel who have access to a terminal. A prototype of the complete system is to be tested sometime during the latter part of 1981.

\subsubsection{Bar Code Reader Systen}

A system for following the location and status of environmental samples was developed which will utilize a bar code reader system. The bar code reader sy'stem will be similar to those used in grocery stores. The system will provide for bar code entry of parameters such as sample number, sample type, location, and technician's initials. The reader should reduce the amount of labor required for sample accounting and help reduce th: number of data errors. The reader system has been ordered and should be received before October 1981.

\subsection{1: OR:HL Environmental and Safety Report}

A constelting $f$ irm was given a centract to write an ORNL Environmental and Safety Report (ESR). The document to be produced will serve as a preliminary document upon which an ORNL Environmental Impact Statement or an Environnental Assessment for ORNL can be based. The ESR is to te completed during 1981 .

As part of the preparatory work for the EIS, an aerial survey of the Oak Ridge Reservation and surrounding areas (out to $10 \mathrm{~km}$ from the reservation boundaries) was conducted. 
4.10.18 Radiological Assessment of Radioactive Waste Disposal Areas at Oak Ridge National Laboratory

Results of 1979 and 1980 TLD surveys of the solid waste disposal areas are being comiled into a report. TLD data for perimeter air monitor and remote air monitor stations are included for comarison. The report should be compieted in 1981 .

\subsubsection{Burial Ground Survey Report}

This publication, ${ }^{7}$ in the final draft stage, contains the results of a February 1979 radiation survey of the internediate-level waste system pipeline. Survey techniques and recomendations for health physics monitoring during cleanup are included.

\subsection{0 .20 water Quality}

In 1980, DEM established sixtien monitoring stations along white Dak Creek and Helton Branch. The stations 1 to 5 ( $P$-permanent) and 1 to 9 (T-temporary) were chosen because of their locations ncar solid waste disposal areas, settling basins, seepage pits, and trenches. Stations P-6 and T-10 served as background stations. Samples (water and sediments) were collected from the monitoring stations for a minimm of four weeks and a maximum of 37 weeks and analyzed for 30 paraneters. The parameters inr'uded carł.on, sulfate, ritrate, phosphorus, alkalinity, hardness, solids (suspended and dissolved), phenol, amonia, nitrogen, chemical oxygen dexand, biochemical oxygen denand, polychlorinated biphenyl (water and sediment), chlorine, wil and grease, and turbidity. The results were compared to the criteria compliance values and measured values of the En;ironmer. . Protection Agency (EPA), National Pollutant Discharge Elimination $S$ ) $t=$ (NPDES), and the literature respectively. The report is baing written and should be completed in 1981 .

\subsubsection{Foodstuff Project}

The fcodstuff project has been completed and a report ${ }^{8}$ published on this project.

Food samples werc obtained from commercial markets and analyzed for stable elements and radionuilides. The concentrations of most stable elements ( $\mathrm{Ag}, \mathrm{Al}, \mathrm{As}, \mathrm{Au}, \mathrm{Ba}, \mathrm{Br}, \mathrm{Ca}, \mathrm{Ce}, \mathrm{Cl}, \mathrm{Co}, \mathrm{Cr}, \mathrm{Cs}, \mathrm{Cu}, \mathrm{Fe}, \mathrm{Hf}, \mathrm{I}$, $\mathrm{K}, \mathrm{La}, \mathrm{Mg}, \mathrm{Mn}, \mathrm{Mo}, \mathrm{Na}, \mathrm{Rb}, \mathrm{Sb}, \mathrm{Sc}, \mathrm{Se}, \mathrm{Sr}, \mathrm{Ta}, \mathrm{Th}, \mathrm{Ti}, \mathrm{V}, \mathrm{Zn}, \mathrm{Ir}$ ) were

${ }^{7}$ An Enviromental Radiologica: Survey of the Intermediate-Level Waste System Pipeline, to be published as ORNL/TM-7858.

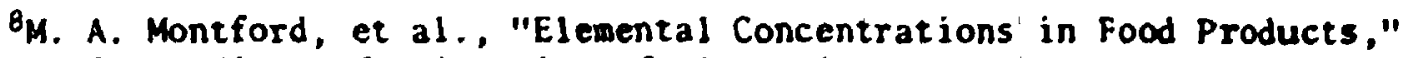
in Proceedings of University of Missouri's 14th Annual Confereille on Trace Substances in Environental Health, Colunbia, Missour June 2-5, 1980, pp. 155-164. 
deternined using uliple-element neutron activation analysis, while the coricentrations of other stable elements ( $\mathrm{Cd}, \mathrm{Hg}, \mathrm{Ni}, \mathrm{Pb}$ ) were determined using atomic absorption techniques. The concentrations of ${ }^{40} \mathrm{~K},{ }^{60} \mathrm{Co}$, ${ }^{95} \mathrm{Zr}-\mathrm{Nb},{ }^{106} \mathrm{Ru},{ }^{125} \mathrm{Si},{ }^{137} \mathrm{Cs},{ }^{226} \mathrm{Ra}$, and ${ }^{232} \mathrm{Th}$ were deternined using gama-ray spectrometry. The concentrations found are compared to other literature values.

\subsubsection{Manuals}

A manual ${ }^{9}$ has been prepared in an effort to promote uniformity among methods of analyzing air, water, terrestrial, and biological saples. It is intended as a bench manual and, therefore, contains considerable detail that would not normally be in such a manual. The procedures will be upgraded and transmitted to those on the distribution list.

\section{Environmental Protection Manual - Procedures}

Changing federal and state regulations require frequent updatirg and addition of procedures. All of the original procedures in the manual were recently updated. Three new procedures were written. These new procedures are for environmental assessments, disposal of used and unwanted chemicals, and air emission permits.

Hazardous Materials Management and Control Manual

The ORNL llazardous Materials Management and Control Mamual was prepared to provide employces with the information necessary for the procurement, use, storagc, transportation, and disposal of hazardous materials/wostes. The Manual is an annual report and will be revised and updated each year. The currant edition was poblished in Jaruar; 1981.

The program, as outlir.cd in the Manual, is administered by two Hazardous Materials Coordinators, one in the Industrial Hygiene Department and one in the Department of Environmental Management. The coordinators act as contacts between the user of hazardous materials and the various Laboratory departmients which serve as support groups in their areas of expertise.

9. W. Oakes, et al., "Methods and Procedures Utilized in Environmental Maragement Ac:ivities at Dah Ridge Natioral LaLoratory, ORNL/TM-7212, March 1981. 
ORNL-OWO. 66-2210

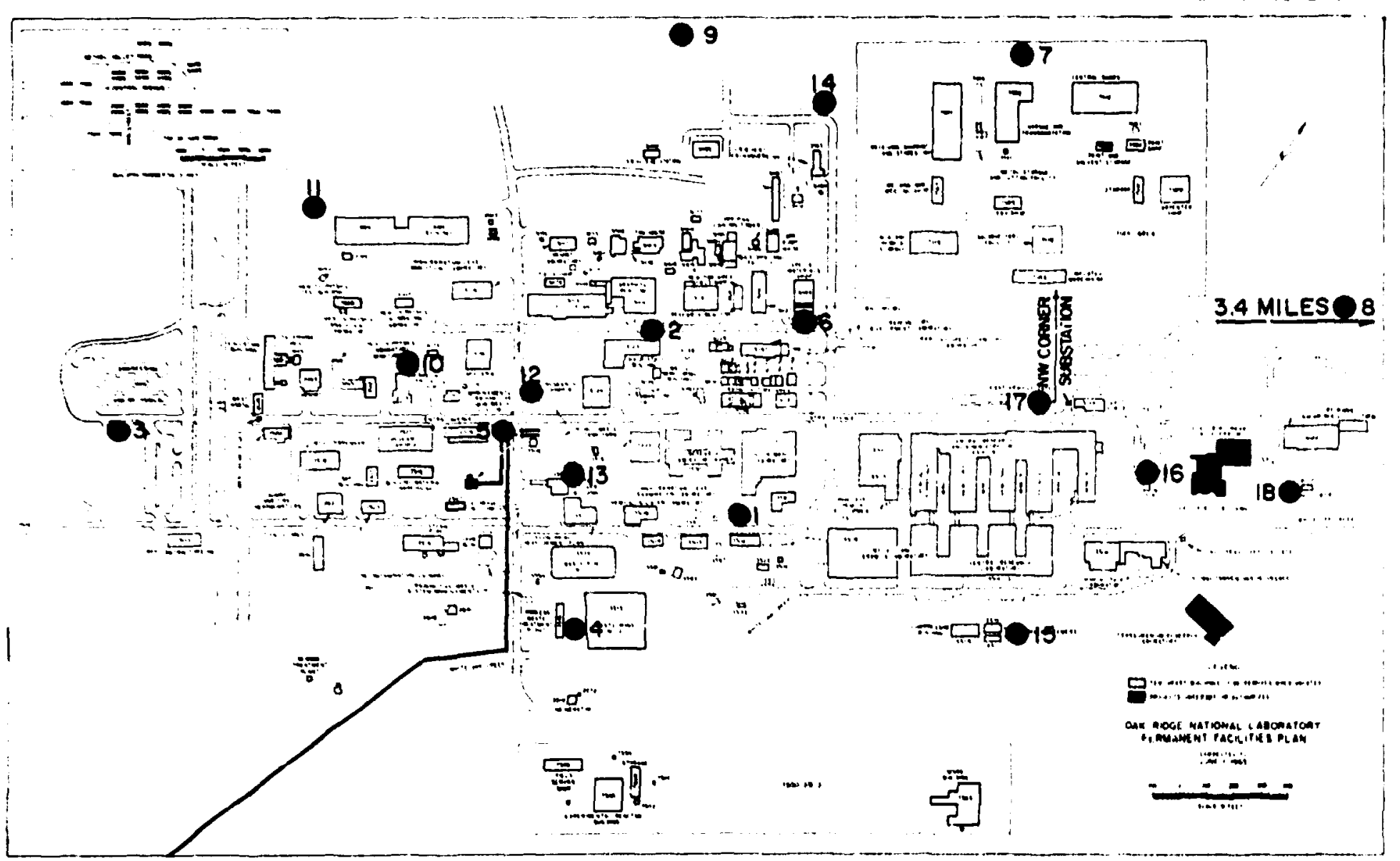

Fig. 4.1.1 Local Air Monitoring (LAM) Network - Bethel Valley 
1

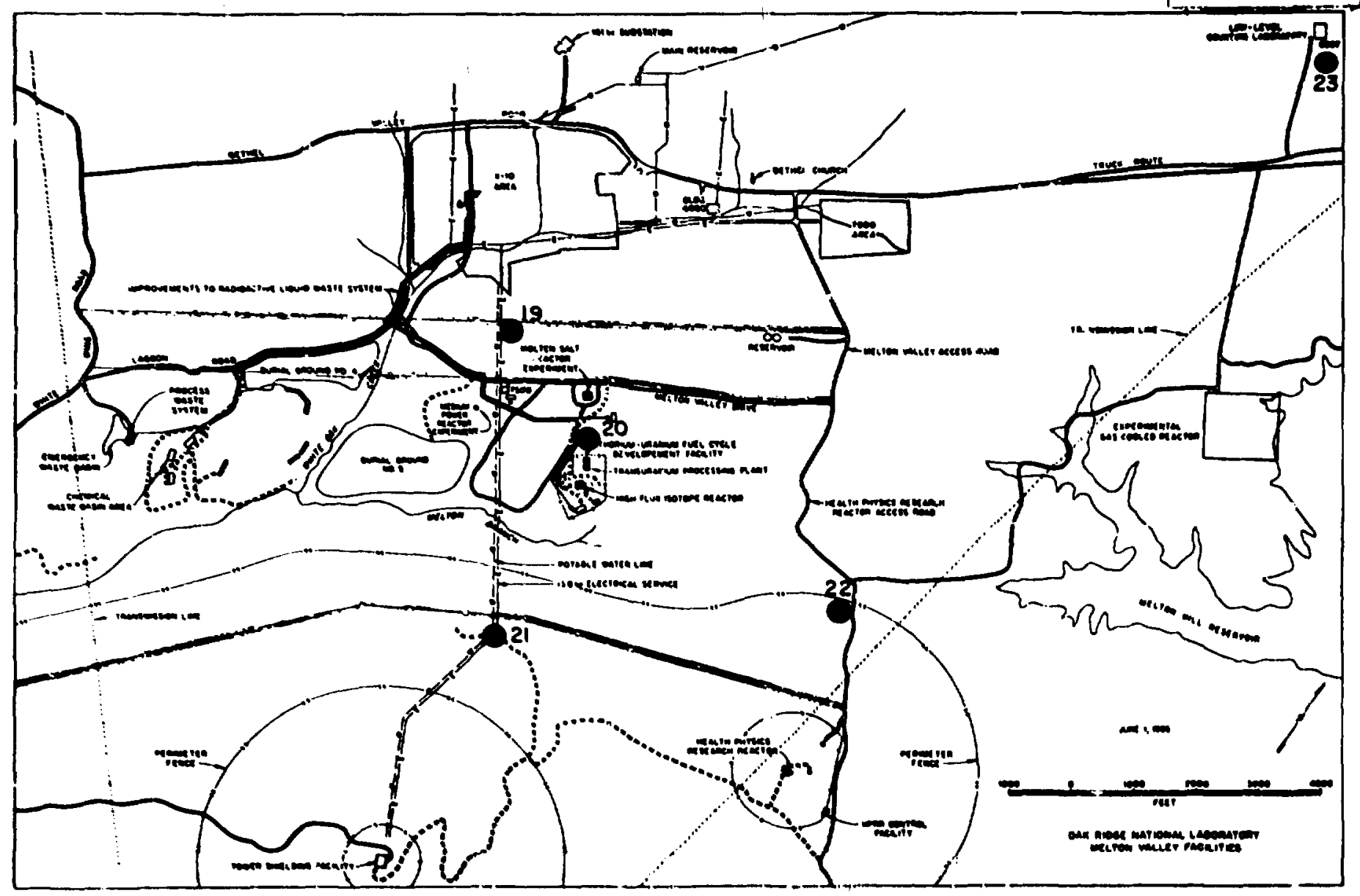

Fig. 4.1.2 Local Air Monitoring (LAM) Network - Outlying Stations 


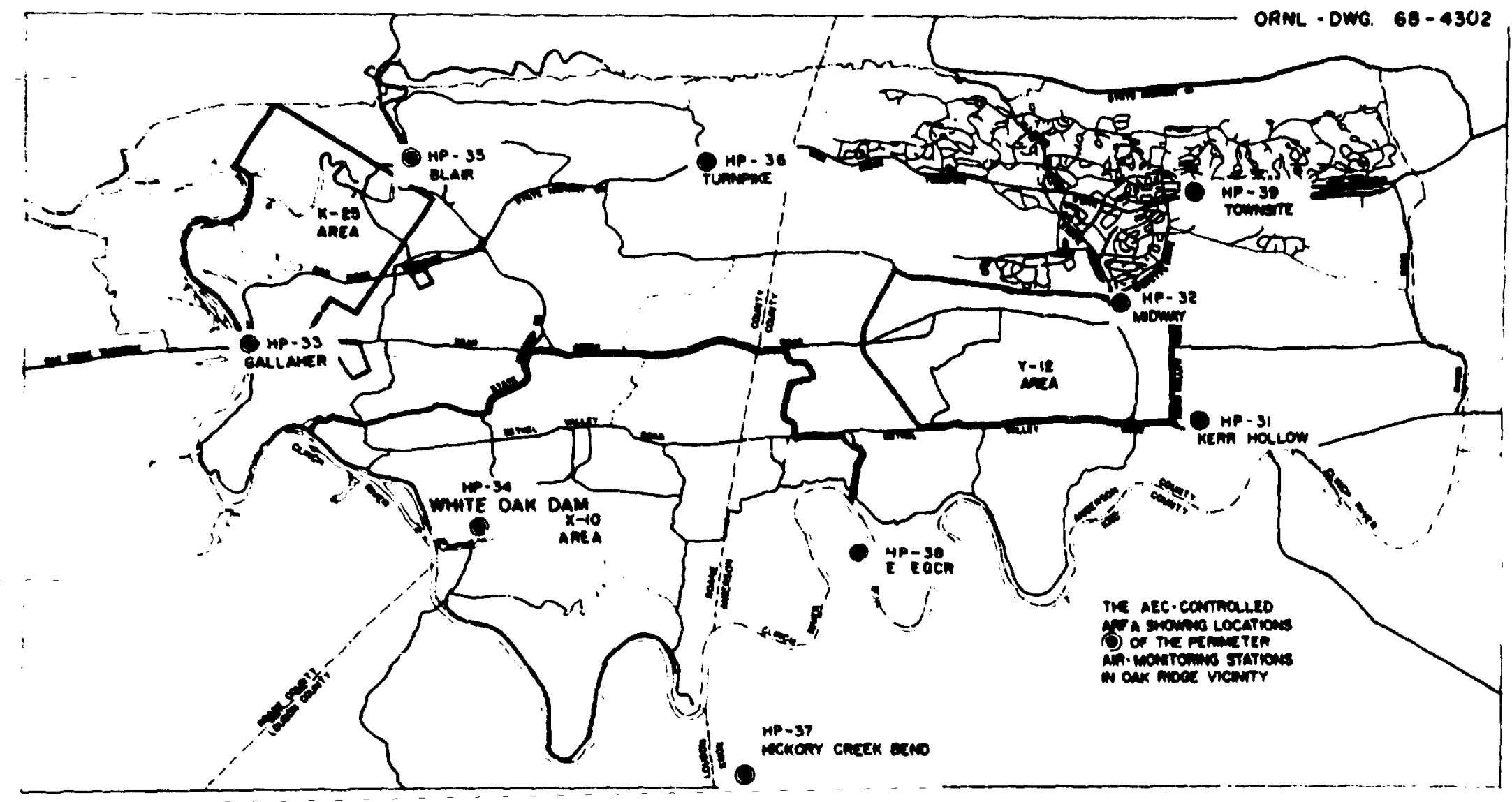

Fig. 4.1.3 Perimeter Air Monitoring (PAM) Network 


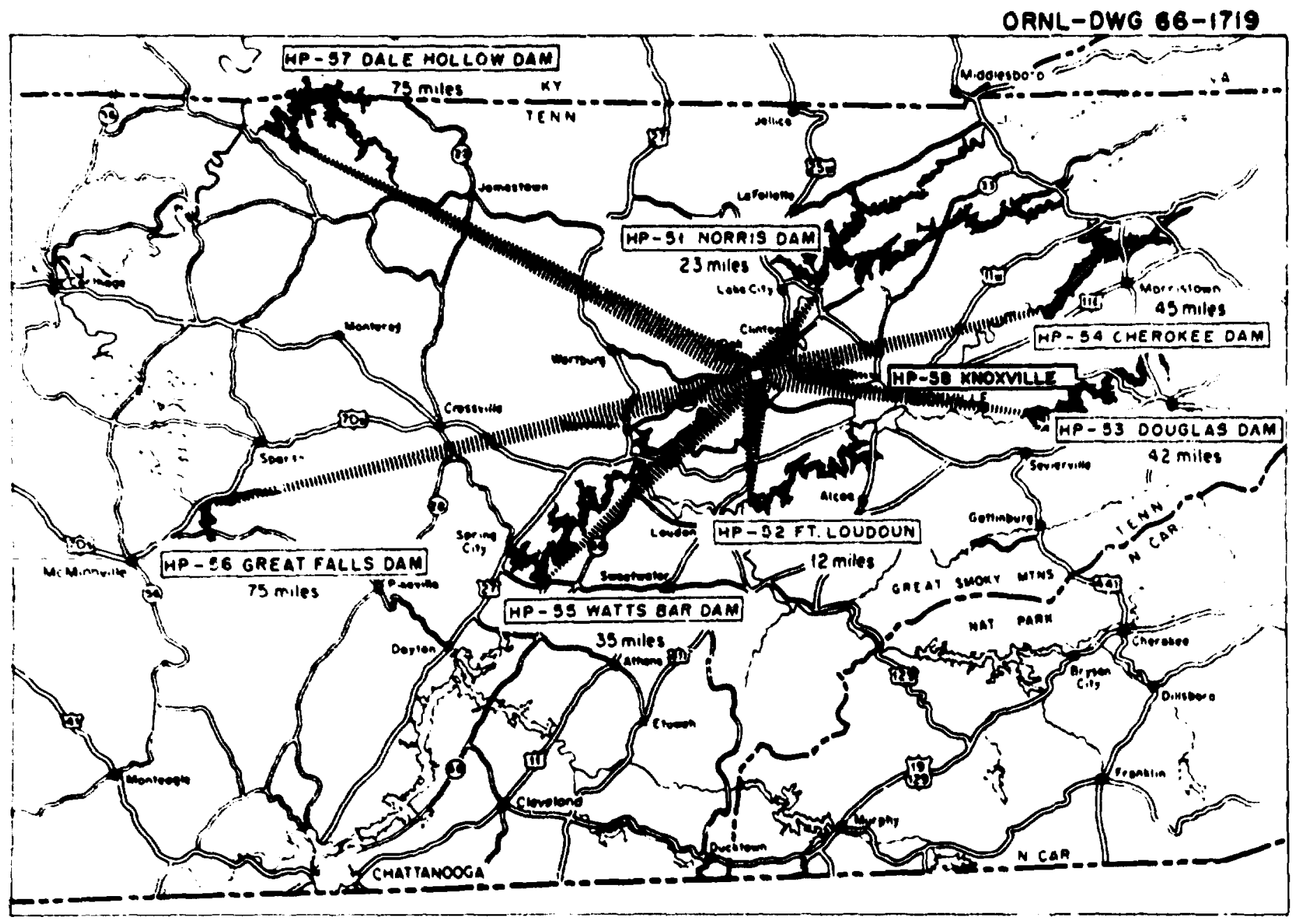

Fig. 4.1.4 Remote Air Monitoring (RAM) Network 


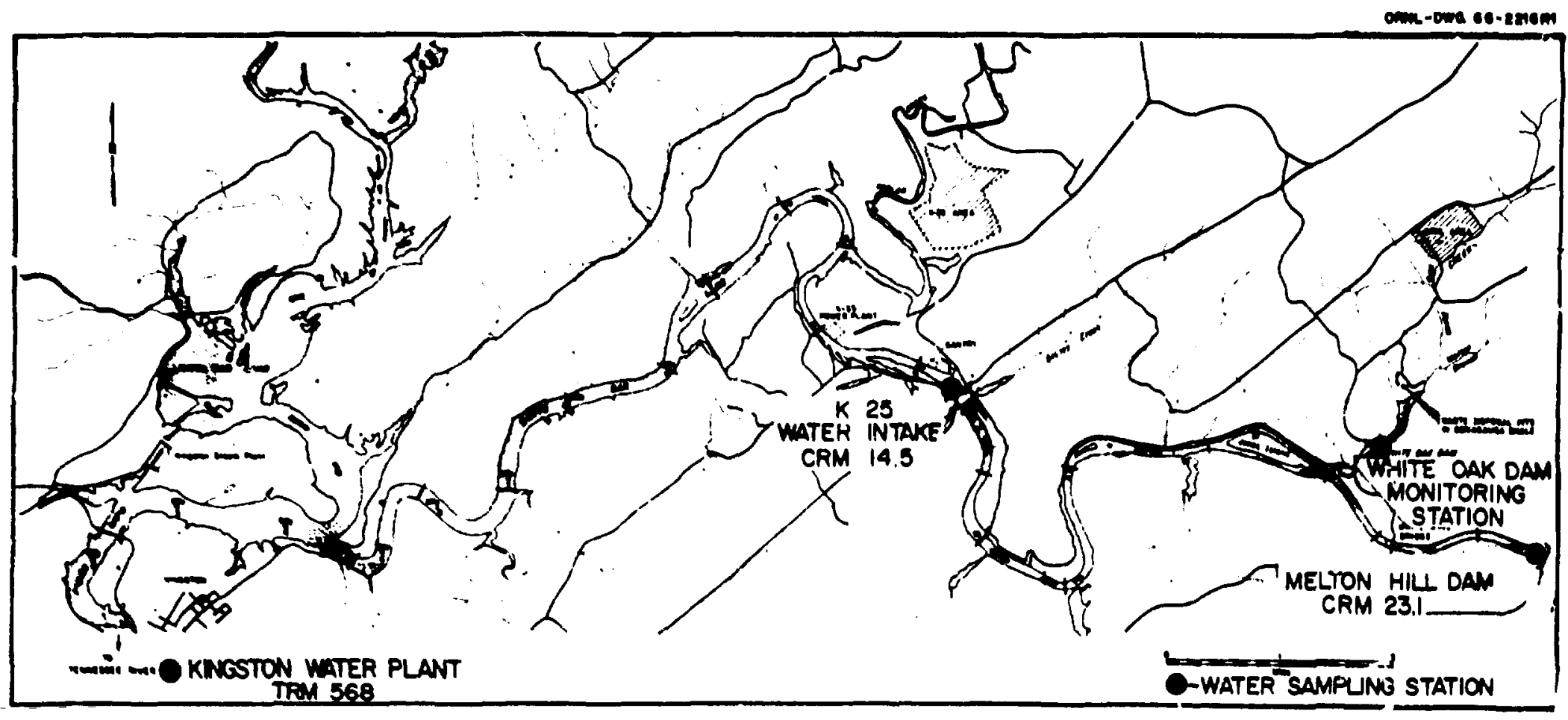

Fis. 4.1.5 Map Showing Water Sampling Locations in the East Tennessee Area 


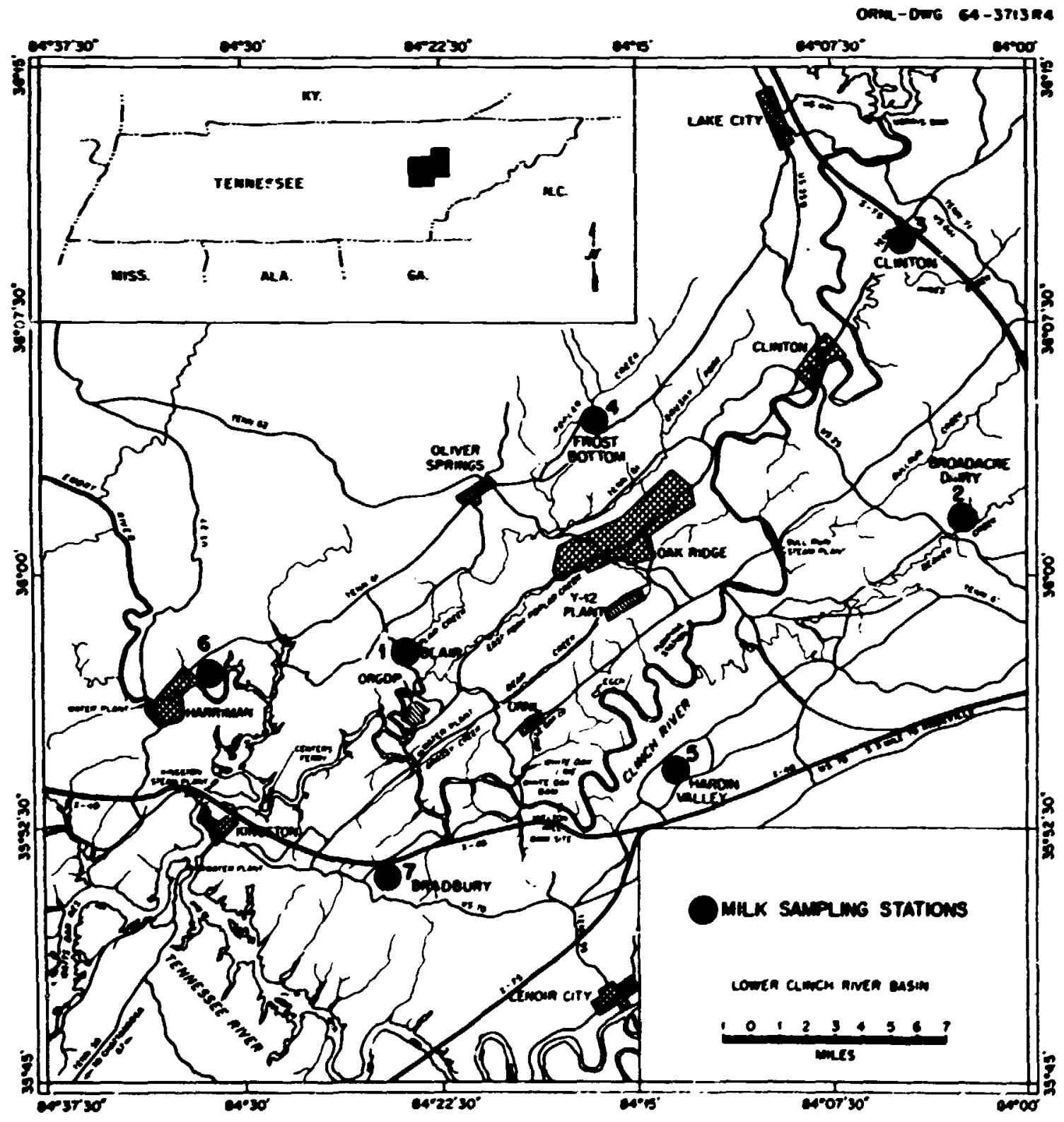

Fig. 4.1.6 ixition of Milk Sampling Stations (Within 20-Mile Radius of ORNL) 


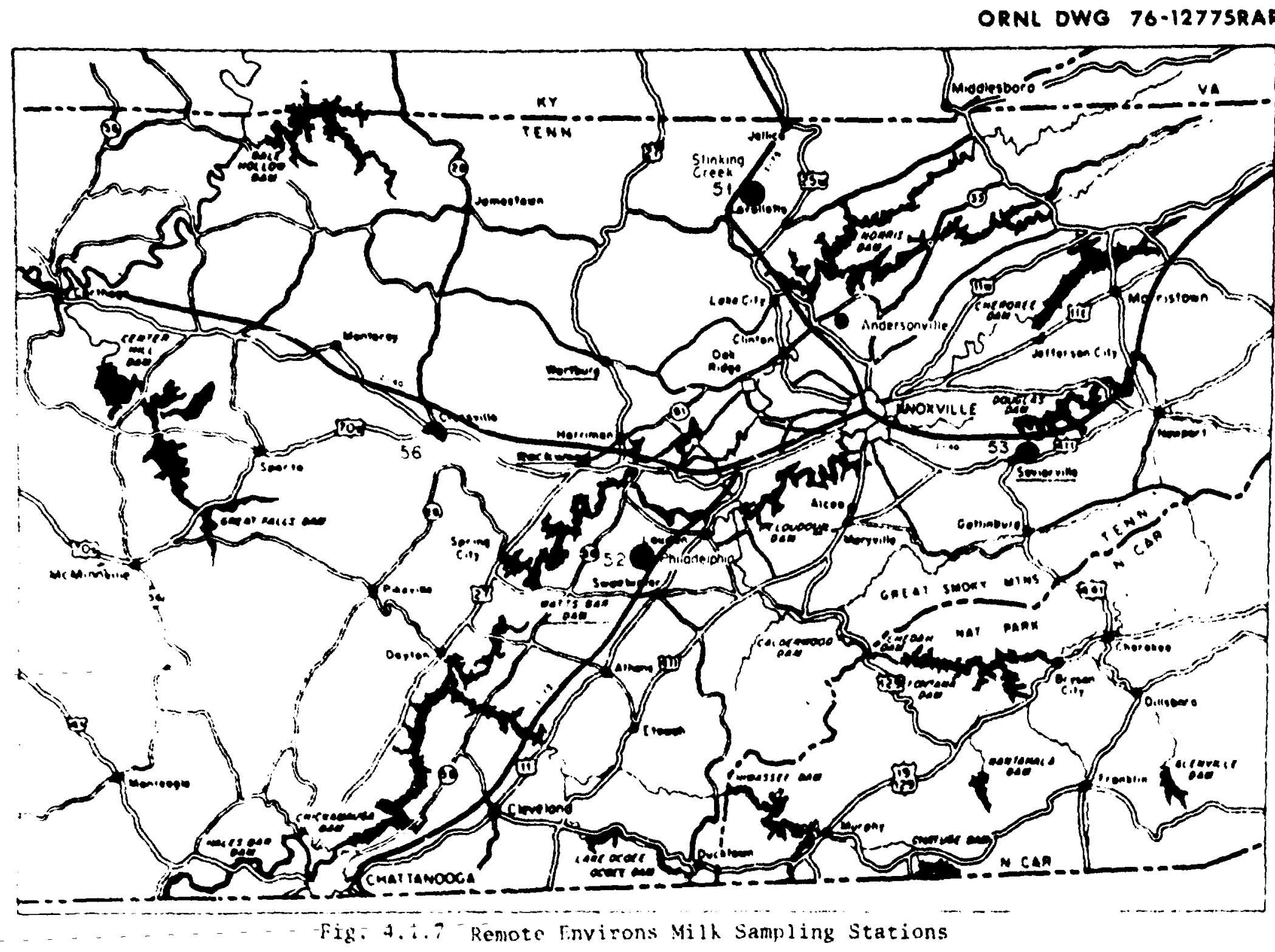




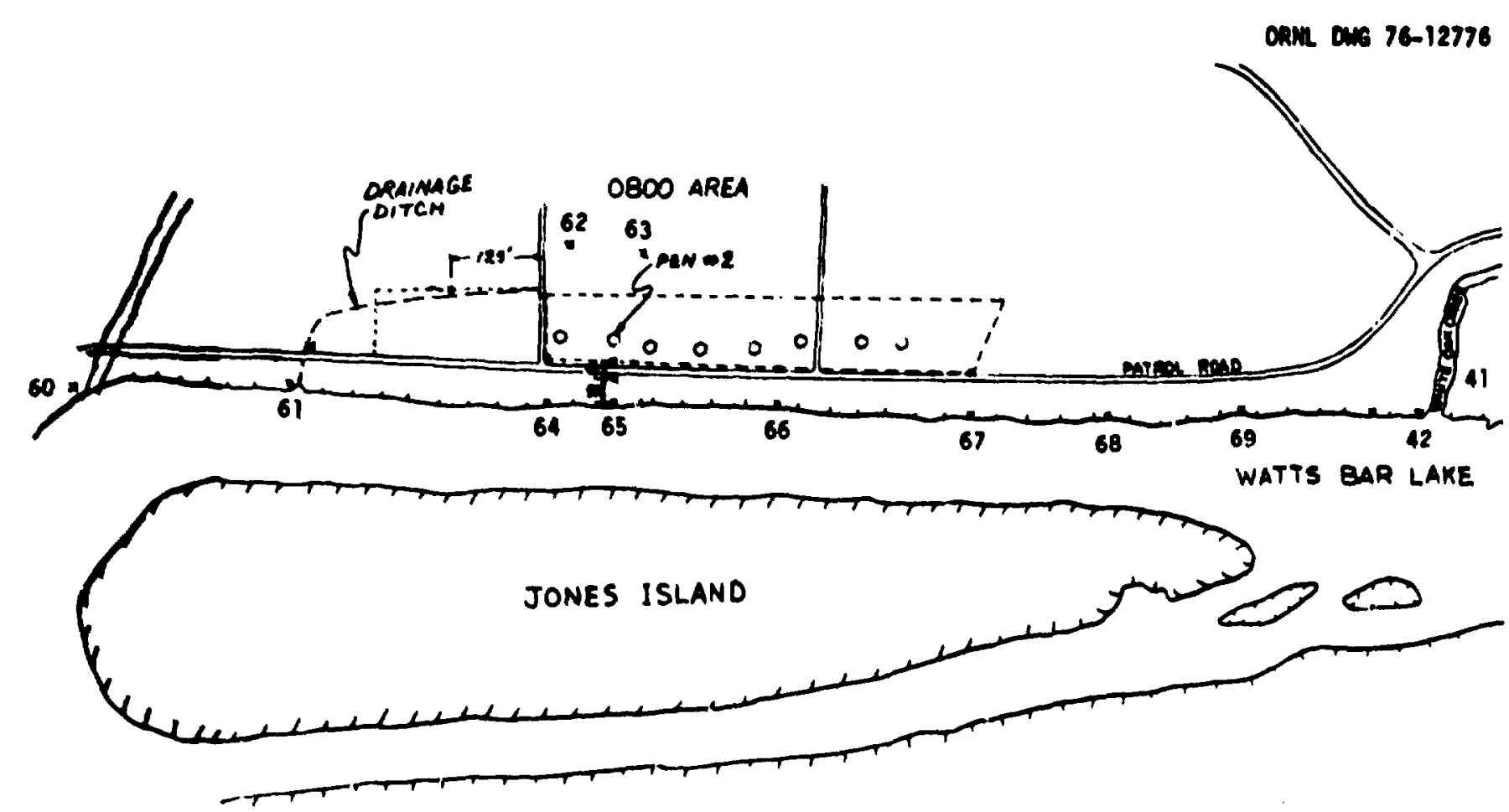

Fig. 4.1.8 Thermoluminescent Dosimeter Locations Along Perimeter of the DOE-Oak Ridge Controlled Area 
Table +.3 .1$

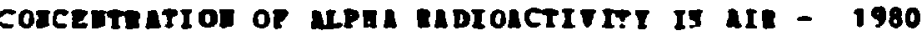
(PILTER PAPE oATA - TRARLT ITERLGE)

\begin{tabular}{|c|c|c|c|}
\hline \multirow{2}{*}{$\begin{array}{l}\text { Station } \\
\text { moaber }\end{array}$} & \multirow[t]{2}{*}{ 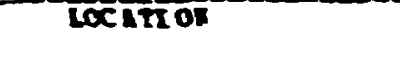 } & \multicolumn{2}{|c|}{ LOSG-LIVED ACTIVITI } \\
\hline & & nICEC-cI/Ce & $B \times c 00$ ERzL5/s \\
\hline & LABOAATOAT AREA & & \\
\hline 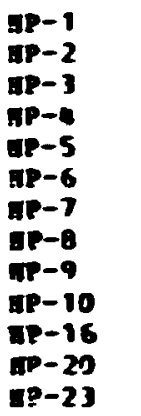 & 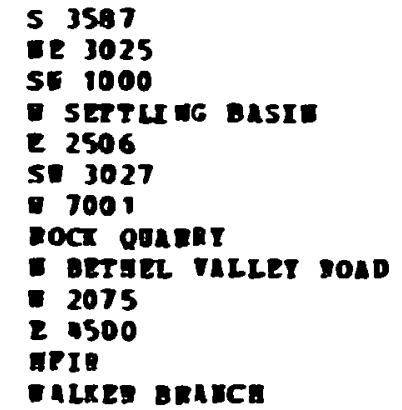 & 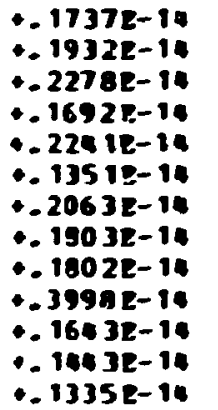 & 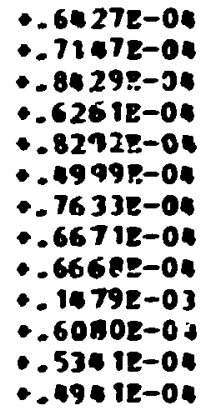 \\
\hline \multirow[t]{2}{*}{ ATERAGE } & & - 1948E- 14 & $. .7206 z-04$ \\
\hline & PERITETES ABEA & & \\
\hline 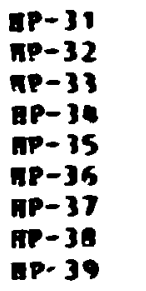 & 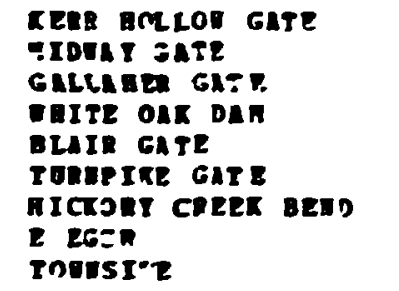 & 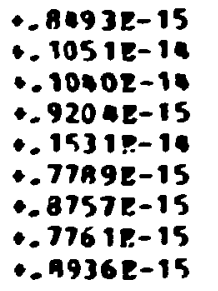 & 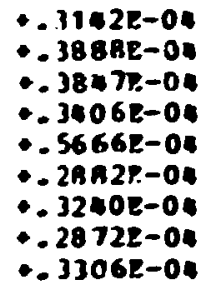 \\
\hline \multirow[t]{3}{*}{ AVERASE } & & $. .9684=-15$ & $-.35838-04$ \\
\hline & RETOTE APRL & & \\
\hline & $-\infty+\infty-\infty$ & & \\
\hline $\begin{array}{l}n P-51 \\
n P-52 \\
R P-53 \\
R P-54 \\
n P-55 \\
A P-56 \\
a P-57 \\
A P-5 P\end{array}$ & 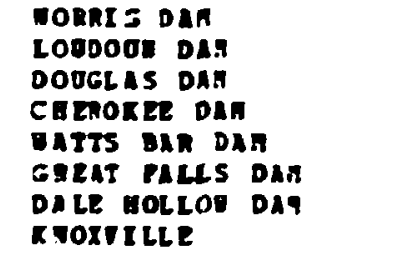 & $\begin{array}{l}\because 1192 z-14 \\
\because 1033 z-14 \\
\because 1006 z-14 \\
\because 1163 z-14 \\
\because 1125 z-14 \\
\because 1238 z-14 \\
\because 1247 z-14 \\
\because 9401 z-15\end{array}$ & 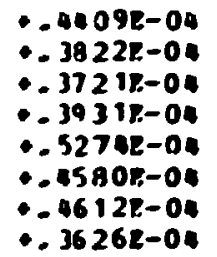 \\
\hline ATERAGE & & $+.118 B E-14$ & $.042272-04$ \\
\hline
\end{tabular}


Table 4.3.2

zocentratrot or bET A RDIOACTIVIT I AIR - 1980 (PILTER PIPE DATL - TBAELT ATERLG)

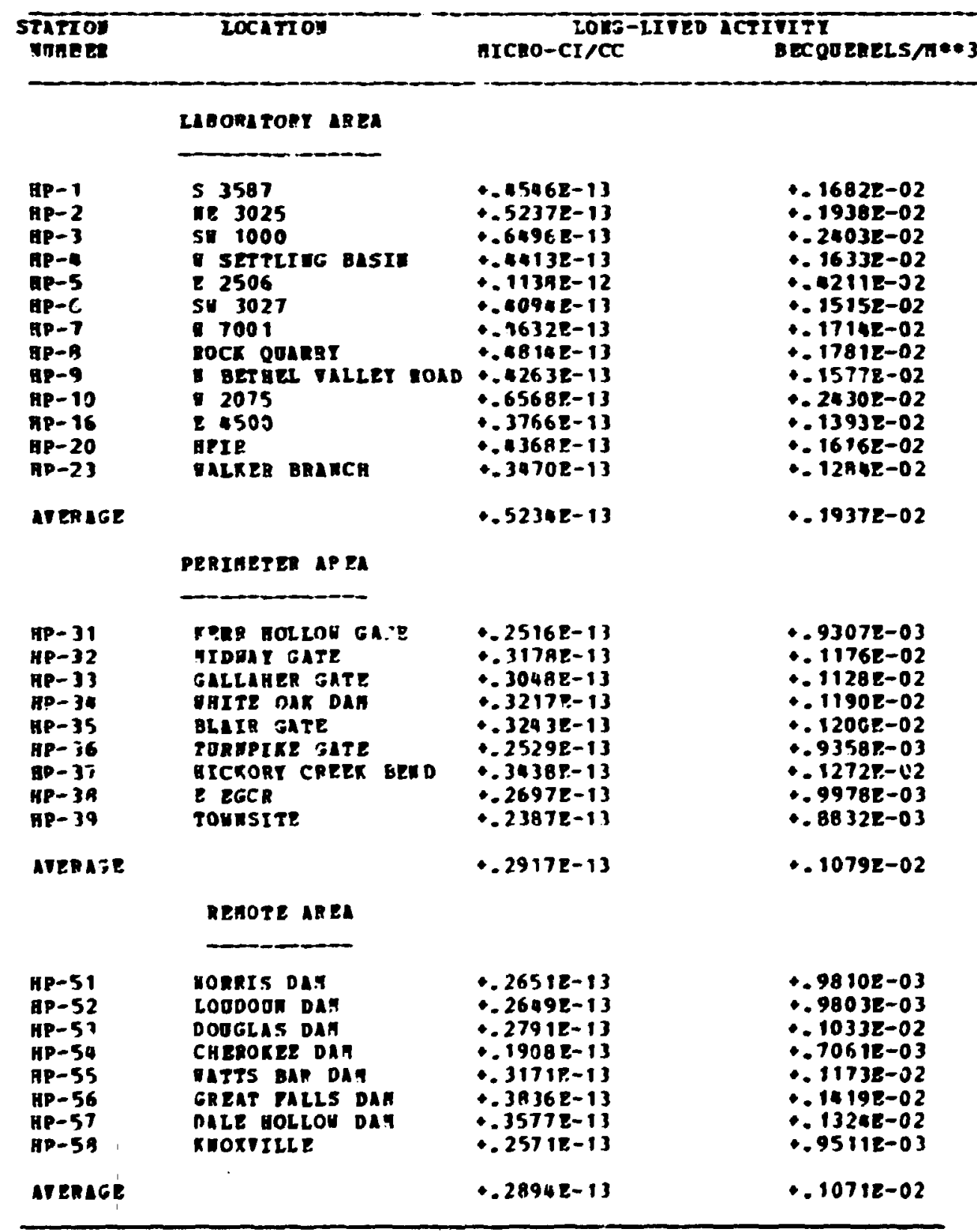


T=uie 4.3 .3

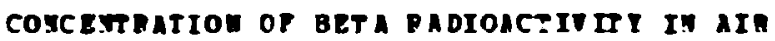
AS DETERIIUES FrOA FILT'P PAPER DATA - 1980 (STSTER ATERAG - oT geERS)

\begin{tabular}{|c|c|c|c|c|c|c|}
\hline \multirow[b]{2}{*}{$\begin{array}{l}\text { veth } \\
\text { 10982a }\end{array}$} & \multicolumn{2}{|c|}{ LES } & \multicolumn{2}{|c|}{ Pats } & \multicolumn{2}{|c|}{ Rasis } \\
\hline & $\begin{array}{c}\text { hICro-cI } \\
r e\end{array}$ & 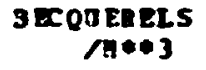 & $\begin{array}{c}\operatorname{arcso}-\mathrm{CI} \\
\mathrm{cc}\end{array}$ & $\begin{array}{c}\text { D xoOEBEI.S } \\
/ 7 * 3\end{array}$ & $\begin{array}{l}\text { nI Cro-CI } \\
/ C C\end{array}$ & $\begin{array}{c}\text { BEcoOen ELS } \\
M \bullet \cdot 3\end{array}$ \\
\hline $\begin{array}{l}1 \\
2 \\
3 \\
1 \\
5 \\
6 \\
7 \\
8 \\
9 \\
10 \\
11 \\
12 \\
13 \\
14 \\
15 \\
16 \\
17 \\
19 \\
19 \\
20 \\
21 \\
22 \\
23 \\
24 \\
25 \\
26 \\
27 \\
28 \\
24 \\
30 \\
31 \\
32 \\
33 \\
34 \\
35 \\
36 \\
37 \\
38 \\
39 \\
10 \\
11 \\
42 \\
43 \\
64 \\
85\end{array}$ & 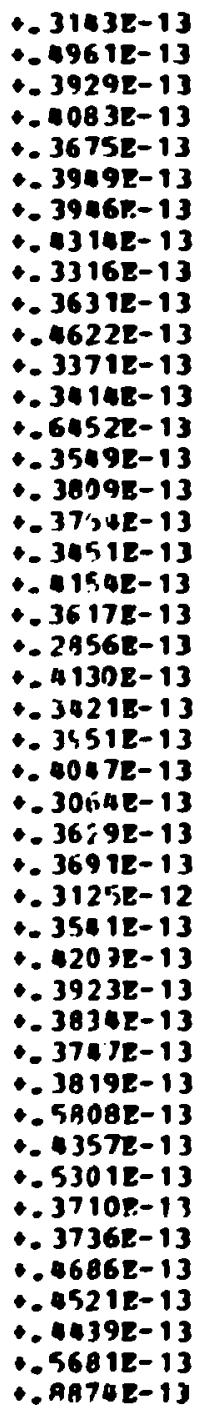 & 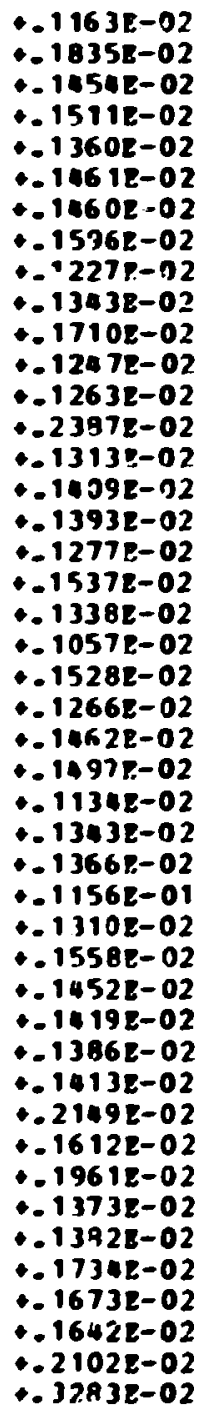 & 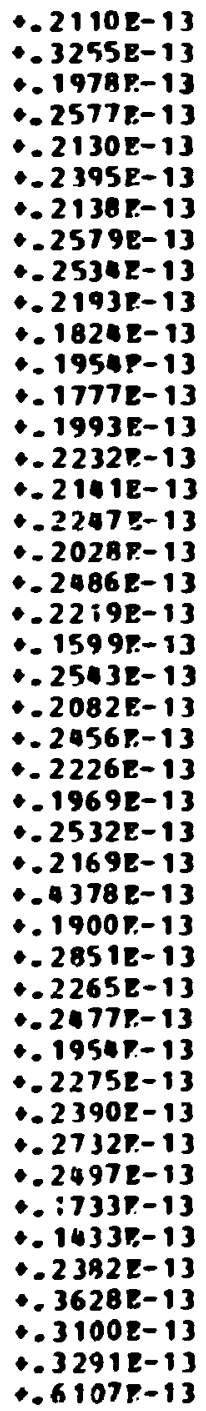 & 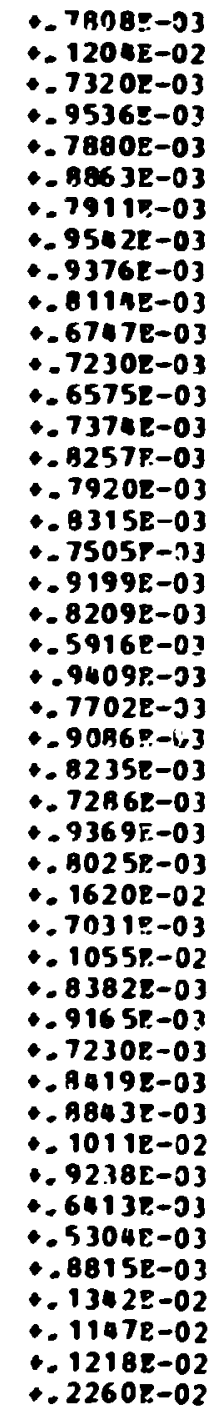 & 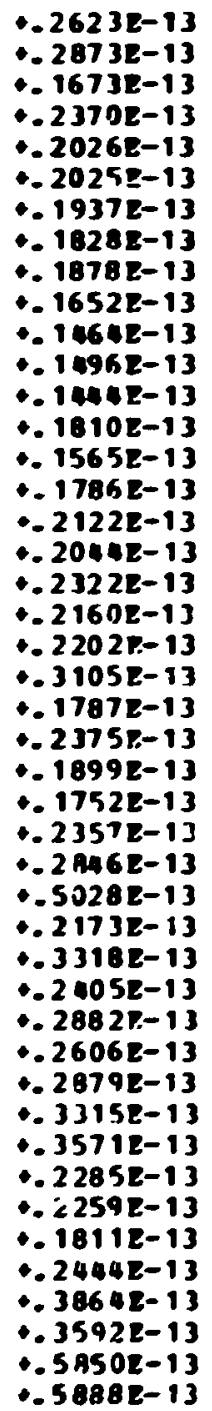 & 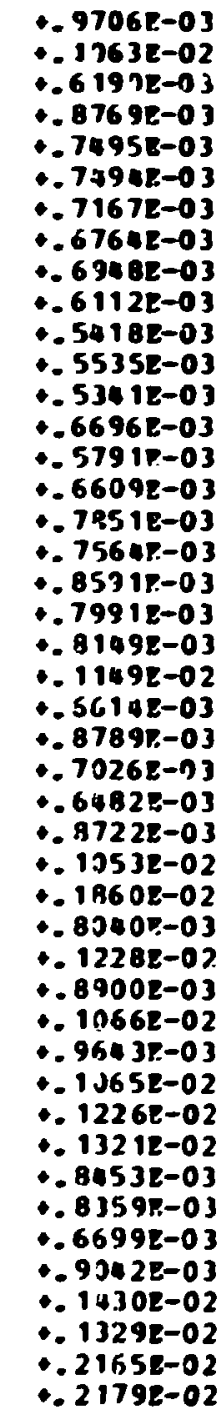 \\
\hline $\begin{array}{l}16 \\
47 \\
48 \\
49 \\
50 \\
51 \\
52\end{array}$ & 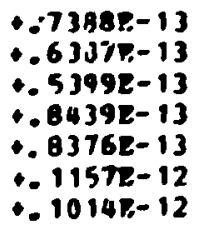 & 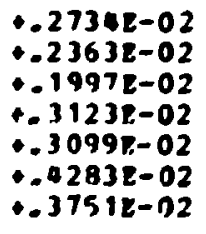 & 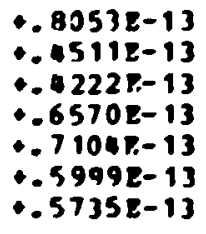 & 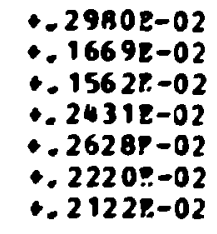 & 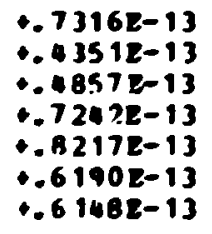 & 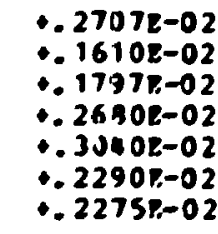 \\
\hline AVEAGE & $+.52138-13$ & $.19298-02$ & $0292 ; 8-13$ & $\because 10812-02$ & $+.30372-13$ & $+.11248-02$ \\
\hline
\end{tabular}


Table 4.3 .4

pasicpiericollet pallout - 1990

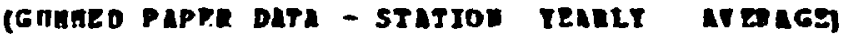

\begin{tabular}{|c|c|c|}
\hline stirros & LOCATI OI & LOIG-LIVED ACTITITI \\
\hline
\end{tabular}

LABOAATOAT AREA

\begin{tabular}{|c|c|c|c|}
\hline 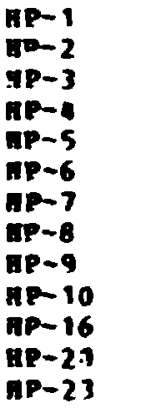 & 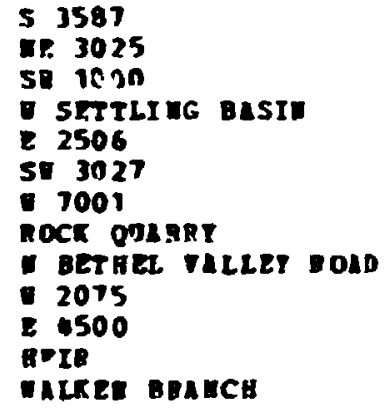 & 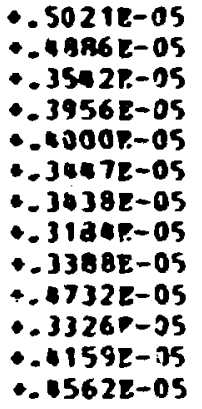 & 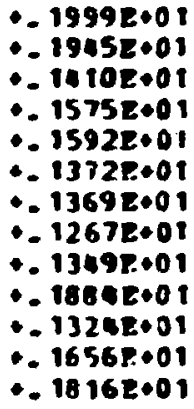 \\
\hline \multirow[t]{2}{*}{ AVERGE } & & $. .3972 E-05$ & $-\quad 15812+01$ \\
\hline & PERIGETER AREA & & \\
\hline $\begin{array}{l}A P-31 \\
A P-32 \\
R P-33 \\
7 P-39 \\
A P-35 \\
4 P-36 \\
A P-37 \\
1 P-39 \\
A P-39\end{array}$ & 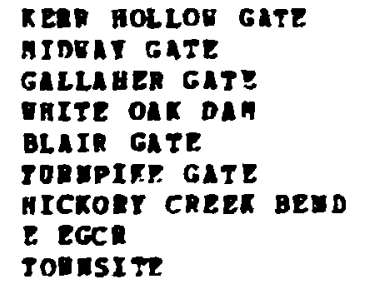 & 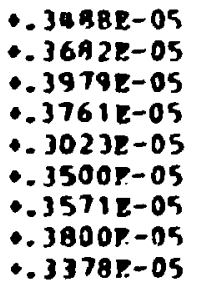 & 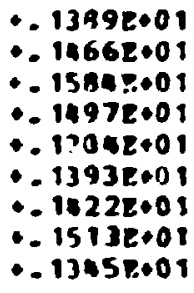 \\
\hline \multirow[t]{2}{*}{ ATENAGE } & & $. .3576 E-05$ & $+14242+21$ \\
\hline & REHOTE AR:A & & \\
\hline $\begin{array}{l}A P-51 \\
M P-52 \\
H P-53 \\
M P-57 \\
H P-55 \\
M P-56 \\
M P-57 \\
M P-59\end{array}$ & 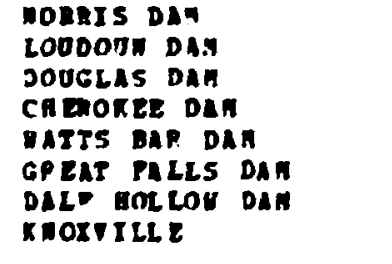 & $\begin{array}{l}. .33568-05 \\
. .30938-05 \\
. .36148-05 \\
.01332-05 \\
.28338-05 \\
.031918-05 \\
. .35587-05 \\
. .26448-05\end{array}$ & $\begin{array}{l}\because 13362+01 \\
\because 12312+01 \\
\because 14392+01 \\
\because 16462+01 \\
\because 11228001 \\
\because 12712+01 \\
\because 16178+01 \\
\because 10692+01\end{array}$ \\
\hline AVERAGE & & $. .33387-05$ &. .13172001 \\
\hline
\end{tabular}


Table 4.3.5

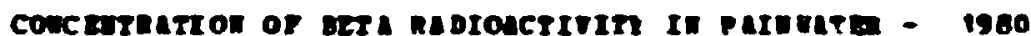
( IEARL ATENGE at starions)

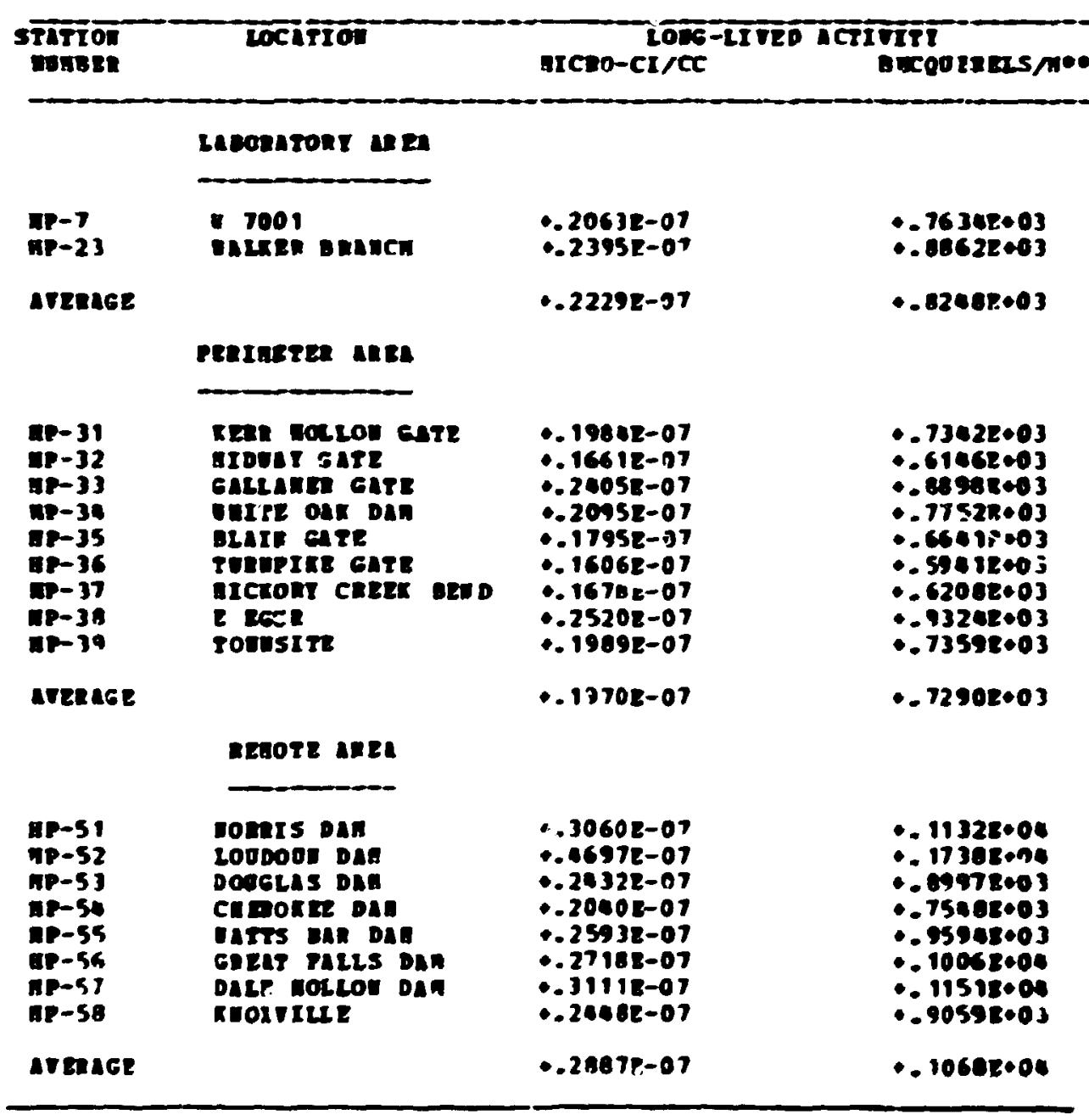




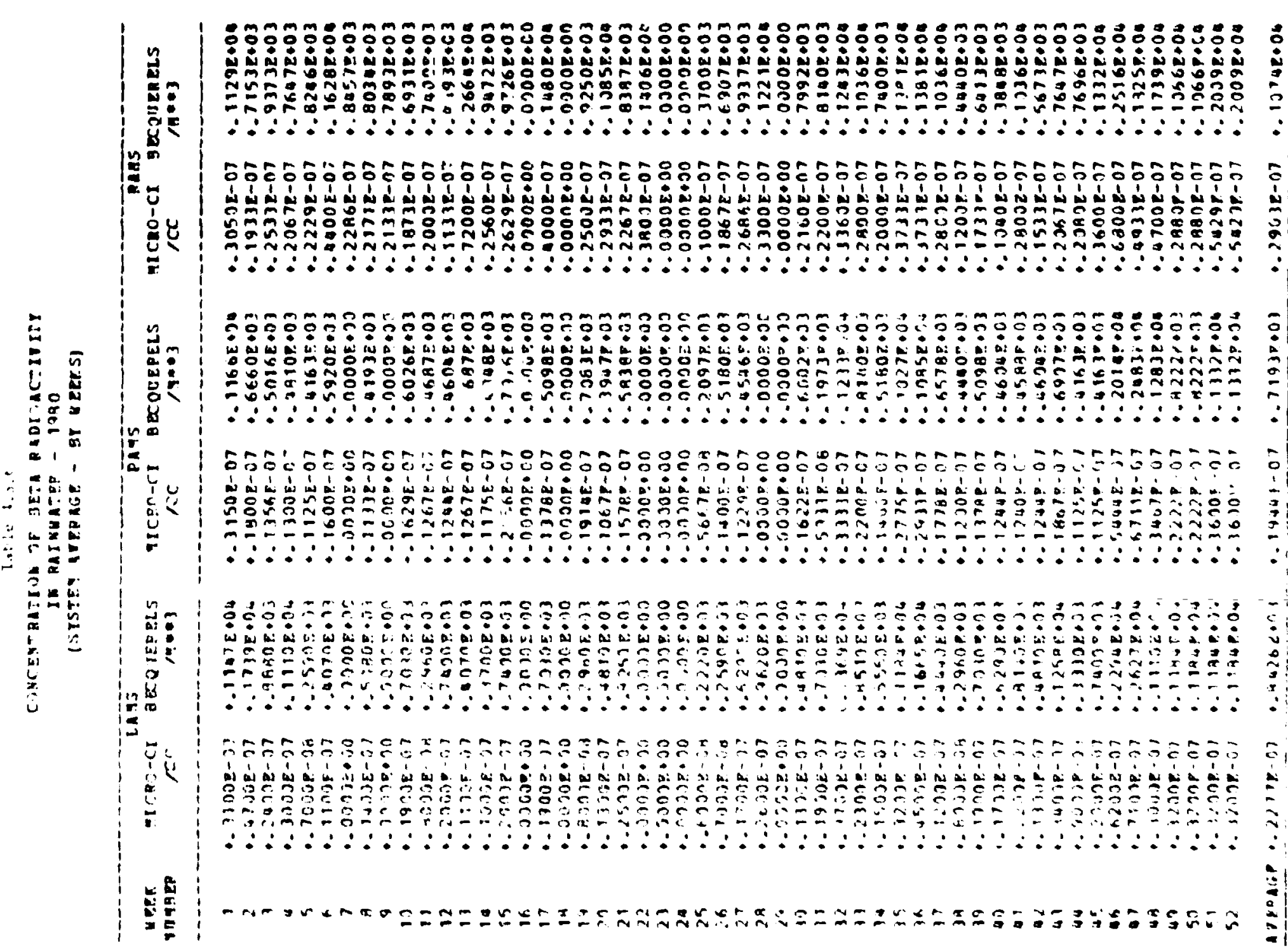




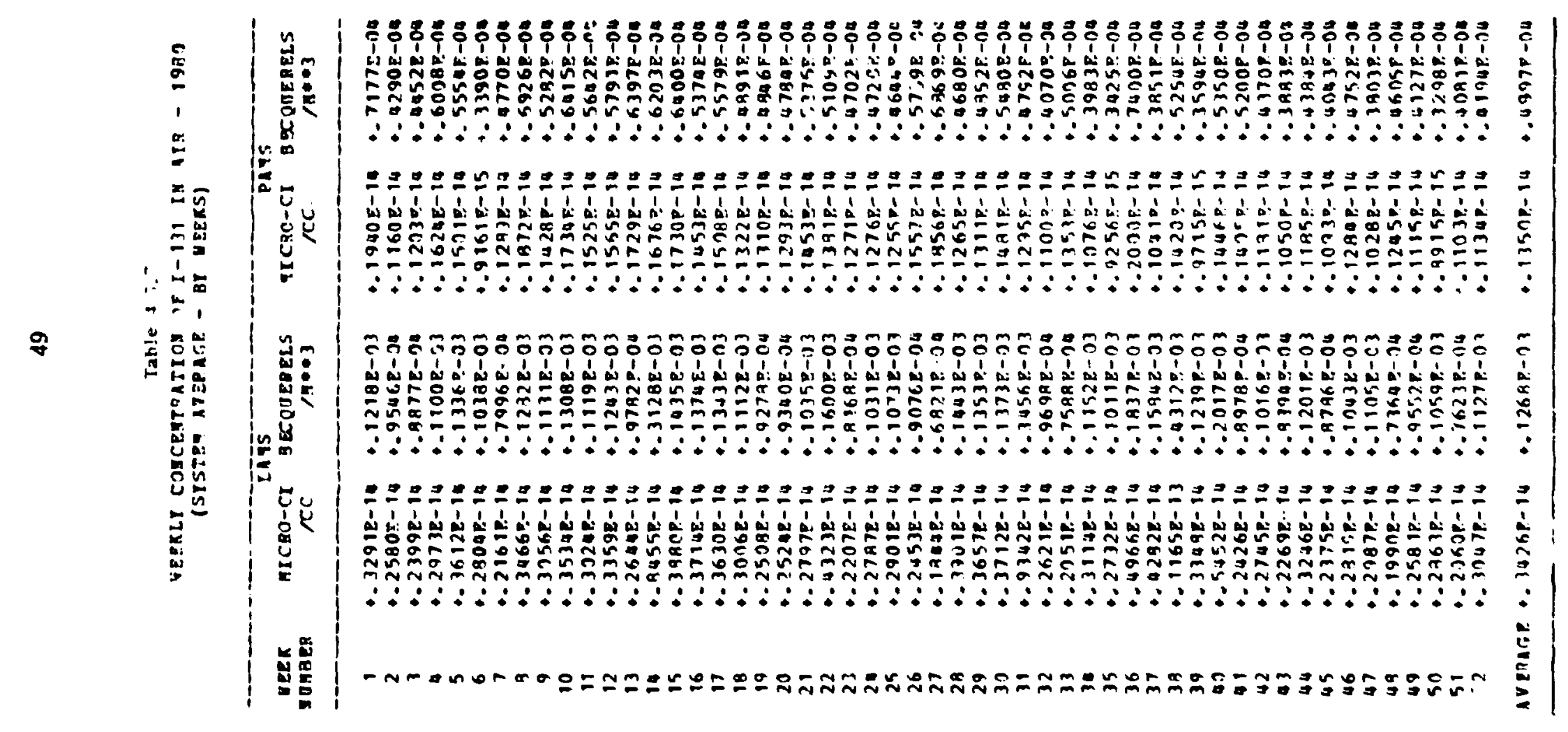


Table 4.3 .8

COMCETTRATION OF TODIUE-131 IM LIR - 1980

( TEARLY ASERAGE BT STATIOAS)

\begin{tabular}{|c|c|c|c|}
\hline $\begin{array}{l}\text { STAEIOA } \\
\text { WHBER }\end{array}$ & LOCATI 0 & $\begin{array}{l}\text { LONG } \\
\text { IICRO-CI } / C C\end{array}$ & $\begin{array}{l}\text { TITt } \\
\text { BEQOERELS }\end{array}$ \\
\hline & LABOPATORT APEL & & \\
\hline $\begin{array}{l}4 P-3 \\
4 P-7 \\
4 P-6 \\
9 P-7 \\
4 P-3 \\
4 P-9 \\
4 P-10 \\
4 P-15 \\
4 P-20 \\
4 P-2 ?\end{array}$ & 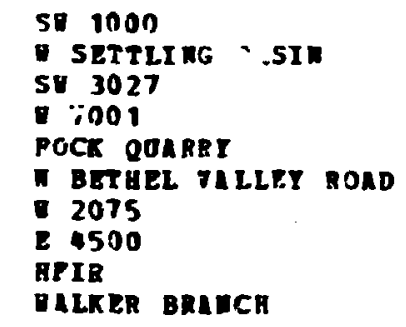 & 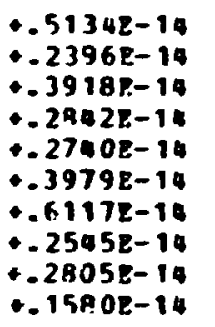 & $\begin{array}{l}\because 1900 E-03 \\
\because 8867 E-04 \\
\because 1449 E-03 \\
\because 10525-03 \\
\because 1014 E-03 \\
\because 872 E-03 \\
\because 2263 E-03 \\
\because 9417 E-04 \\
\because 1038 E-03 \\
\because 5445 E-04\end{array}$ \\
\hline RTERASE & & $+.34068-14$ & $.12608-03$ \\
\hline & PERIAETER AR EA & & \\
\hline $\begin{array}{l}H P-31 \\
H P-32 \\
B P-33 \\
7 P-34 \\
H P-35 \\
H P-36 \\
H P-37 \\
H P-39 \\
H P-37\end{array}$ & $\begin{array}{l}\text { RERR BOLLOL GATE } \\
\text { GIDRAT GATE } \\
\text { GLLLAHE GATE } \\
\text { EHITE OAK DAA } \\
\text { BLAIA GATE } \\
\text { TORJPIKE GATE } \\
\text { RICKORT CAEEK BEN } \\
\text { E RGCR } \\
\text { TOWHSITE }\end{array}$ & 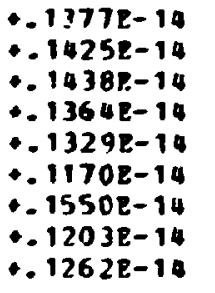 & 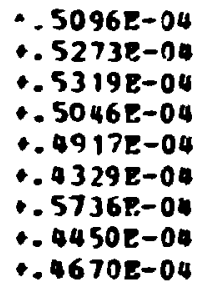 \\
\hline AVERASE & & $+.13468-14$ & $. .4982 \mathrm{E}-04$ \\
\hline
\end{tabular}


Table 4.3.9

Continuow Air Monitaring Dat Specific Radioauclides in Air-1980 (Composite Samples)

[Units of B, m $\times 10^{-3}$ and $\left(\mu \mathrm{C}, \propto c \times 10^{14}\right)$ ]

\begin{tabular}{|c|c|c|c|}
\hline \multirow[b]{2}{*}{ Radionuclides } & \multicolumn{3}{|c|}{ Yearly Average } \\
\hline & Local Stations & Perimeter Stations & Remote Stations \\
\hline 'Be & $380(104)$ & $360(96)$ & $303(82)$ \\
\hline${ }^{21} \mathbf{S} r$ & $0.85(0.21)$ & $0.30(0.08)$ & $0.41(0.11)$ \\
\hline${ }^{100} \mathbf{R u}$ & $3.7(0.97)$ & $1.8(0.49)$ & $1.6(0.44)$ \\
\hline ':s Sb & N.A. & $0.41(0.11)$ & $048(0.13)$ \\
\hline "Cs & $3.8(1.03)$ & $1.4(0.37)$ & $0.92(0.25)$ \\
\hline${ }^{1+s} \mathrm{Ce}$ & $16(4.37)$ & $3.6(0.98)$ & $3.2(0.87)$ \\
\hline$\because \mathrm{Nh}$ & $0.18(0.05)$ & $0.15(0.04)$ & $0.07(0.02)$ \\
\hline$\therefore$ "Th & $015(0.04)$ & $0.11(0.03)$ & $0.04(0.01)$ \\
\hline$\because$ Th & $0.22(0.06)$ & $0.11(0.03)$ & $0.03(0.009$ \\
\hline$\because 4 \mathrm{U}$ & $0.99(n 27)$ & $2.2(0.60)$ & $0.15(0.04)$ \\
\hline$: " \mathrm{U}$ & $0.07(0.02)$ & $0.07(0.02)$ & $0.01(0.004)$ \\
\hline${ }^{i n} \mathbf{U}$ & $0.59(0.16)$ & $1.1 \quad(0.29)$ & $0.07(0.02)$ \\
\hline$\therefore$ Pu & $0.01(0.003)$ & $0.004(0.001)$ & $0.0015(0.0004)$ \\
\hline$\therefore \mathrm{Pu}$ & $0.02(0.006)$ & $0.01(0.004)$ & $0.0015(0.0004)$ \\
\hline
\end{tabular}


Table 4.3.10 Air Monitoring Data - Suspended Particulates 1980

\begin{tabular}{cccccc}
\hline Location $^{2}$ & $\begin{array}{c}\text { Number } \\
\text { of } \\
\text { Samples }\end{array}$ & Maxima & Minima & Average & Std. \\
\cline { 3 - 6 } LAM-1 & 37 & 135 & 11 & 44 & 59 \\
LAH-3 & 34 & 98 & 9 & 40 & 53 \\
LAM-6 & 34 & 75 & 13 & 42 & 56 \\
LAH-7 & 8 & 95 & 18 & 44 & 59 \\
LAM-15 & 30 & 87 & 11 & 38 & 51 \\
\hline
\end{tabular}

${ }^{\mathrm{a}}$ See Fig - 4.1.1.

b Tennessee Air Pollution Control Regulations-Primary standard based on annual geometric mean is $75.0 \mathrm{\mu g} / \mathrm{m}^{3}$. 


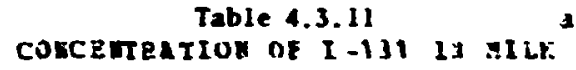

19.40

\begin{tabular}{|c|c|c|c|c|}
\hline spatror & $\begin{array}{c}\text { MongeB } \\
\text { uf }\end{array}$ & SIYIAOR. & & COAP AF ISU: \\
\hline yonber & SAIPLES & 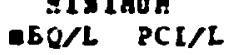 & $\mathrm{at} \times \mathrm{L}=\mathrm{PCI} / \mathrm{L}$ & SEARDAE JE \\
\hline
\end{tabular}

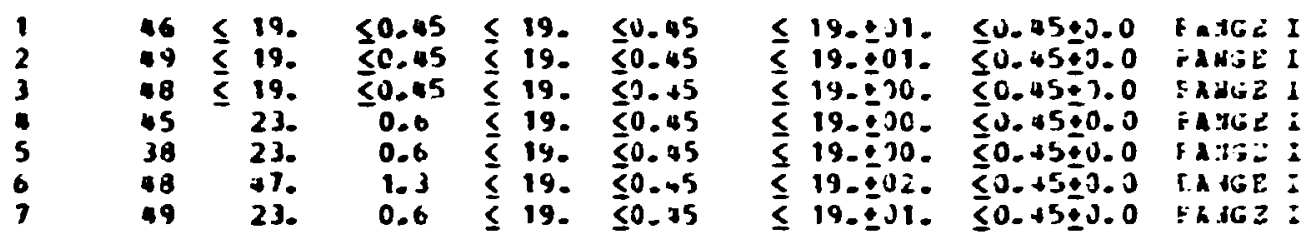

RTERAGE

$\leq 19 . \pm 00 . \leq 3 .+5 \pm 0.0$

กะRCTE E\#YIRU!S

e

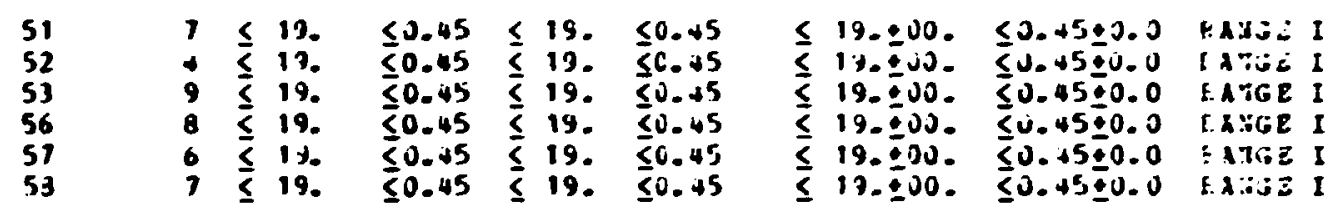

ATERAGE

$\leq 19 . \div 00 . \leq 0.45 \pm 3.0$

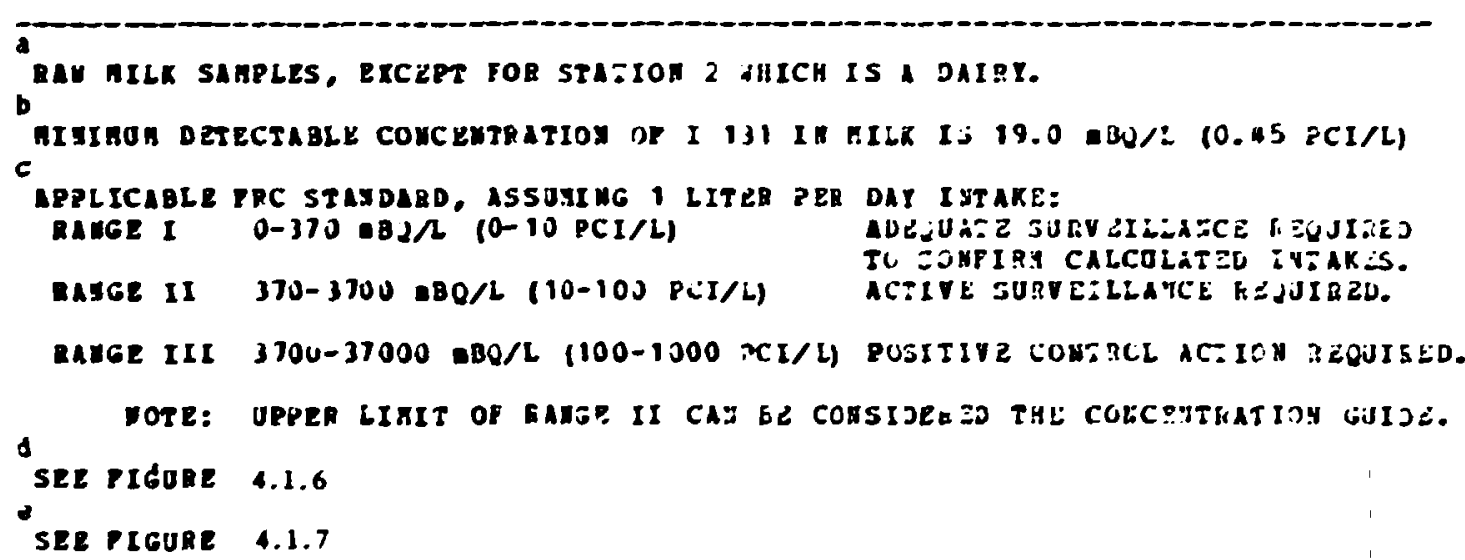


Table 4.3.12

comprotration of $3 R-90$ In GILK

1930

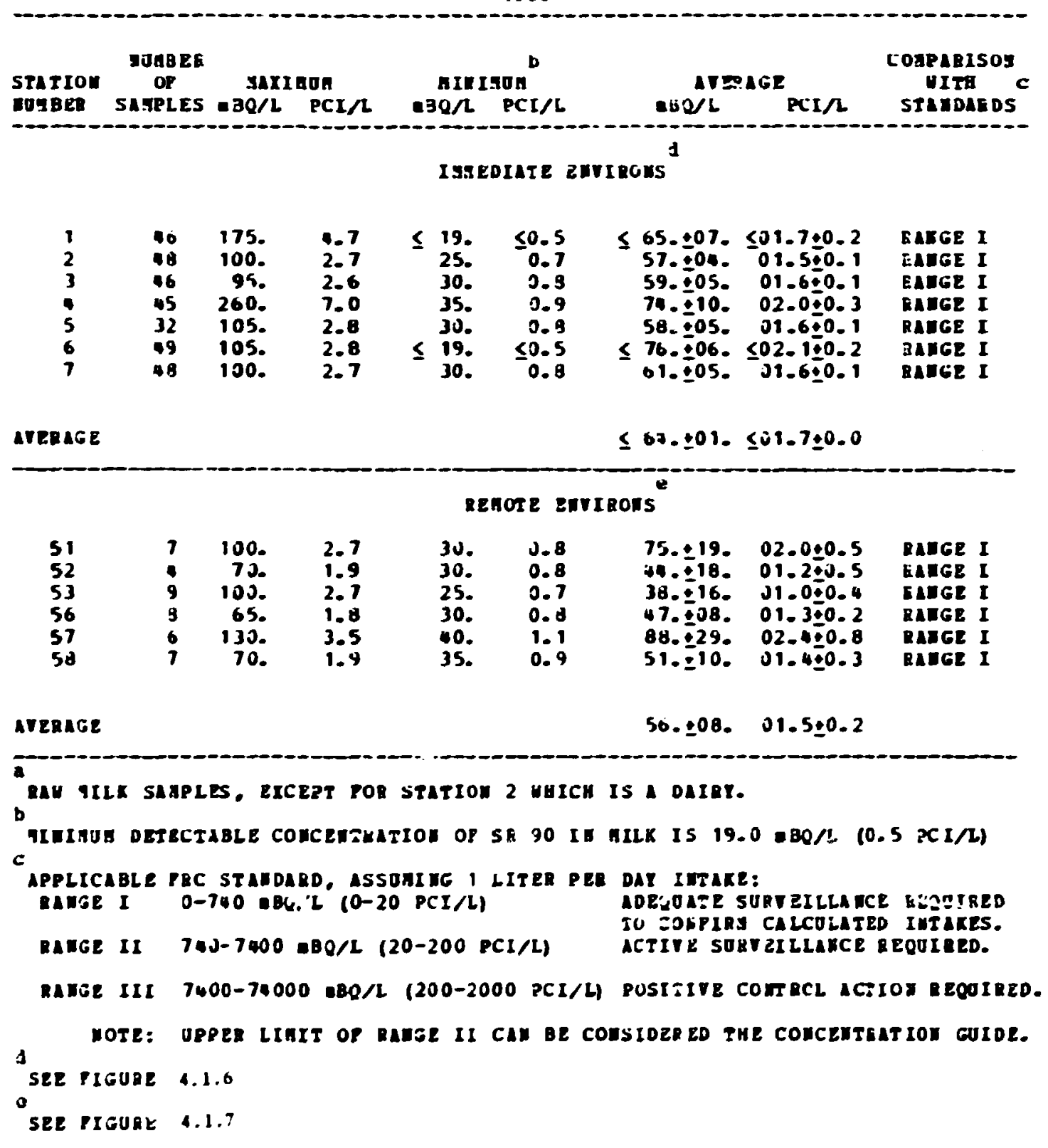


Table 4.3.13 Annual Discharges of Radionuclides to the Atmosphere

\begin{tabular}{|c|c|c|c|c|c|c|c|c|c|c|c|}
\hline \multirow{2}{*}{ Stack } & \multirow{2}{*}{ Number } & \multicolumn{2}{|c|}{${ }^{3} \mathrm{H}$} & \multicolumn{2}{|c|}{$85 k r$} & \multicolumn{2}{|c|}{$\mid 3 I_{I}$} & \multicolumn{2}{|c|}{${ }^{13}{ }^{3} x e$} & \multicolumn{2}{|c|}{$\begin{array}{c}\text { Unidentified } \\
\text { Alpha }\end{array}$} \\
\hline & & $T B q$ & $(k C i)$ & $T B q$ & (kCi) & $\mathrm{GBq}$ & (Ci) & $T B q$ & $(\mathrm{kCl})$ & & $($ ( \\
\hline 3039 & & 536 & $(14,5)$ & 279 & $(. .6)$ & 4.1 & $(0.11)$ & 1361 & $(36.9)$ & & \\
\hline 7025 & & 11 & $(0.29)$ & & & & & & & & \\
\hline 7911 & & & & 45 & $(1.2)$ & 4.1 & $(0.11)$ & 220 & $(6,0)$ & & \\
\hline $\begin{array}{l}\text { Bldg; } \\
\text { Stack }\end{array}$ & $\begin{array}{l}9204-3 \\
(Y-12)\end{array}$ & & & & & & & & & 180 & $(4.8)$ \\
\hline Trans & Lab & & & & & & & & & 2.8 & $(0.08)$ \\
\hline 4509 & & & & & & & & & & 1.5 & $(0.04)$ \\
\hline Total & & 547 & $(14.8)$ & 324 & $(8.9)$ & 8.1 & $(0.22)$ & 1582 & $(42.8)$ & 180 & $(4.9)$ \\
\hline
\end{tabular}

ada furnished by Operations Division. 


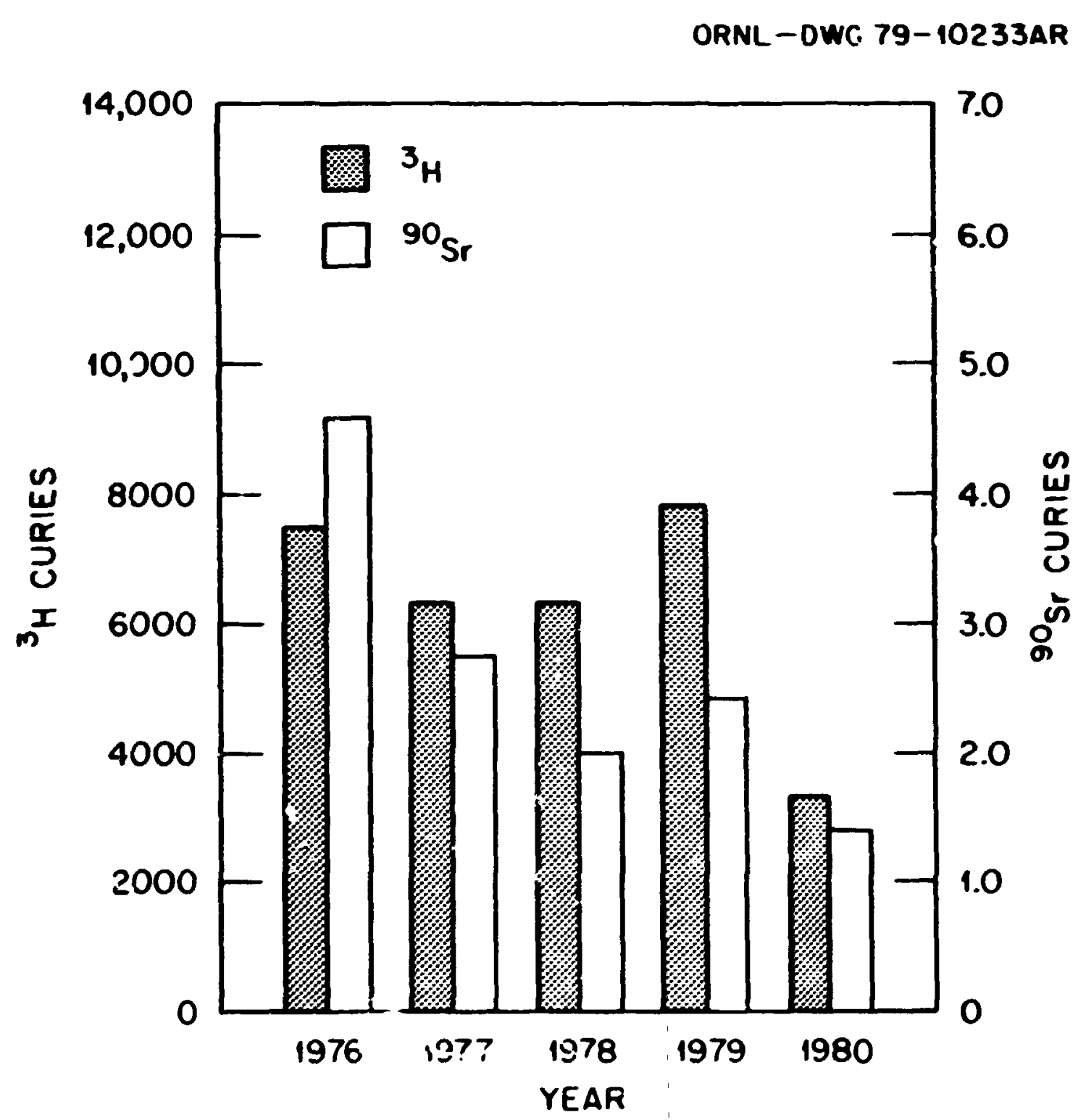

Fig. 4.4.1 Curies ${ }^{a}$ Discharged Over White Oak Dam

${ }^{\mathrm{a}}$ To convert to tera becquerels, multiply ctries by 0.037 . 


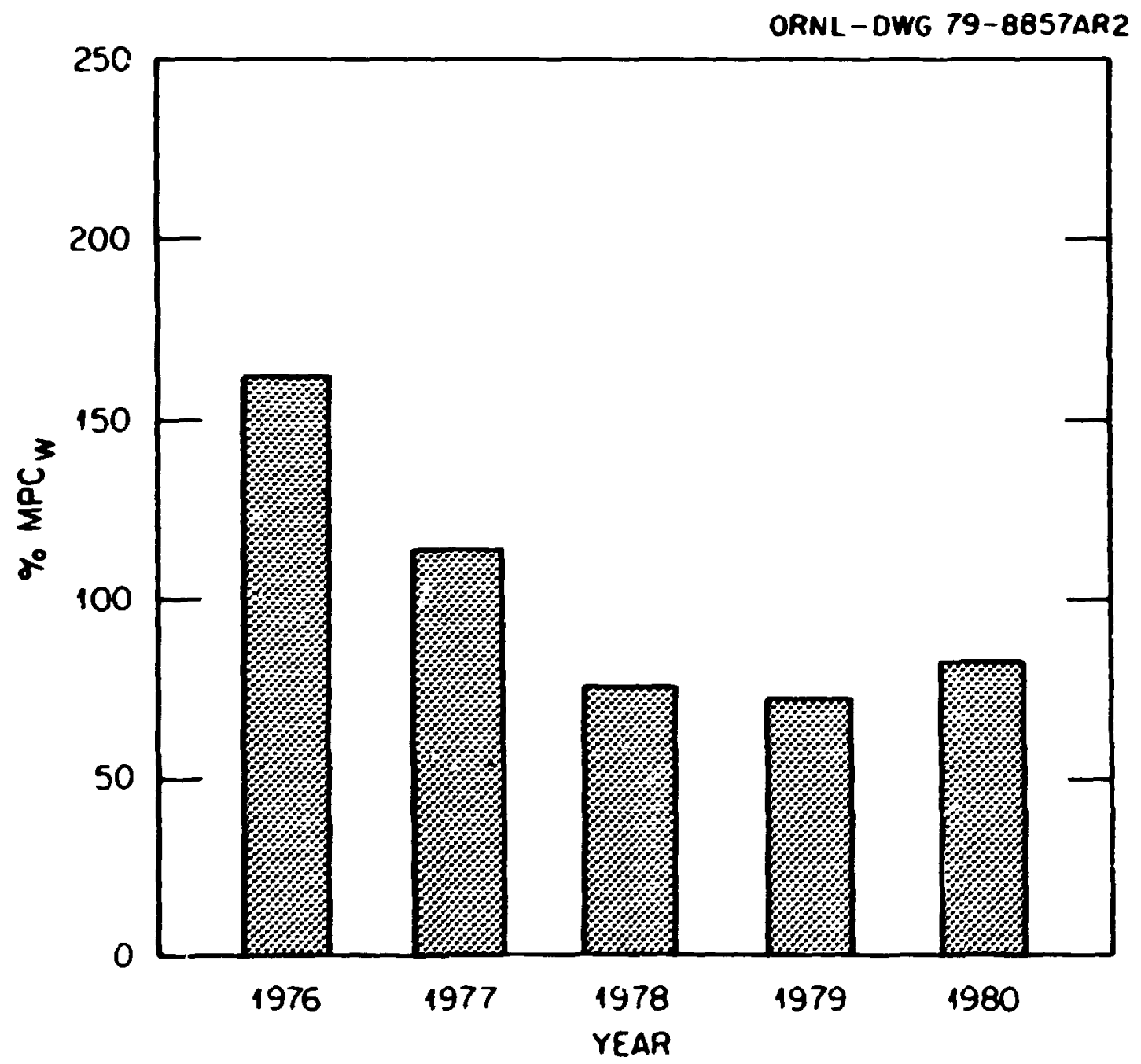

Fig. 4.4.2 Total $: \mathrm{PC}_{w}$ Levels Discharged Over White Oak Dam 


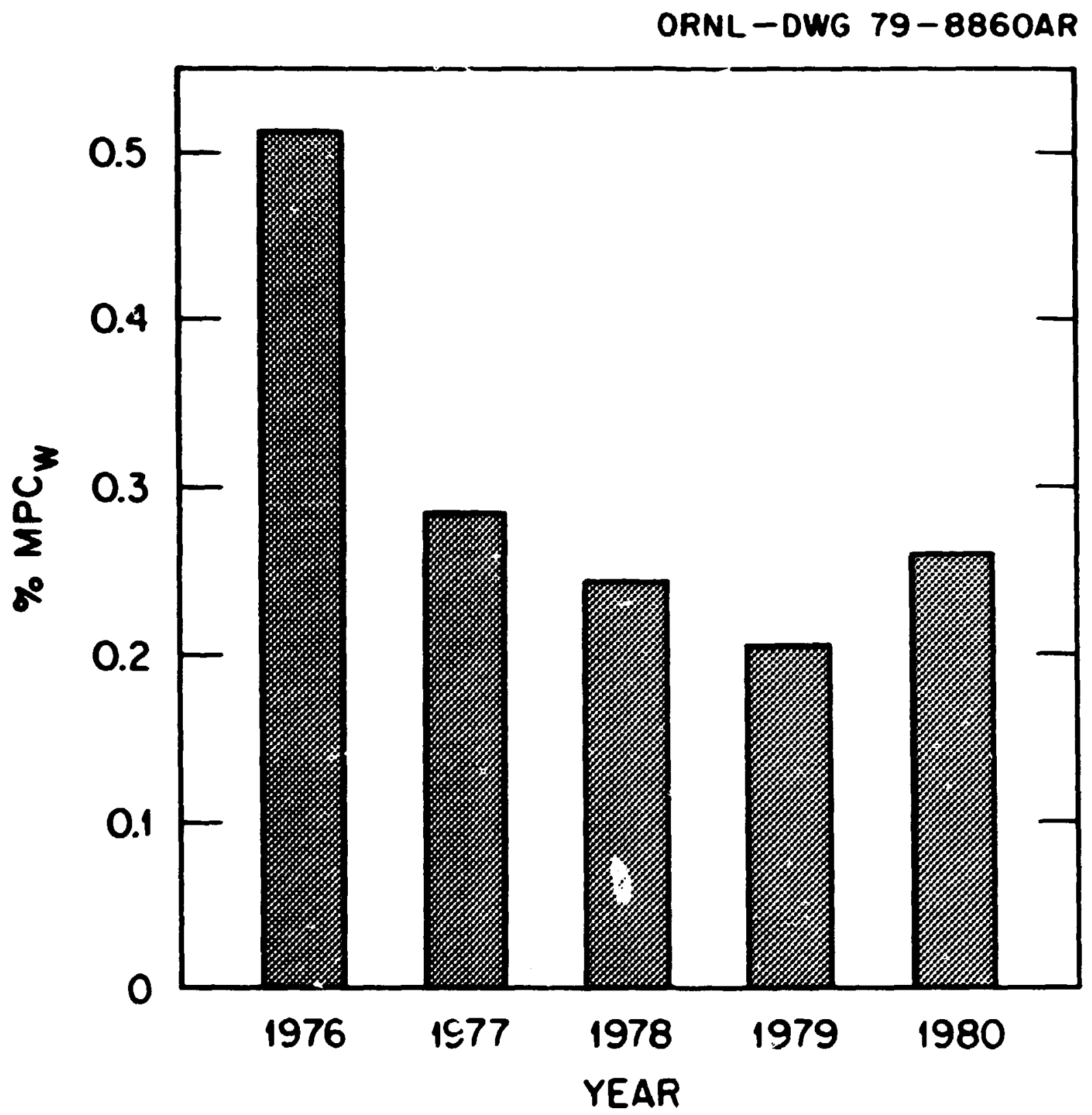

Fig. 4.4.3 Percentage Concentration Guide Levels in the $\mathrm{Clinch}$ River Values given are calculated valucs based on those concentrations measured at White Oak Dam and dilution :: rorded by the Clinch River) 
Table 4.4.1 Anmual Discharges of Radionuclides to the Clinch River (Curies) a

\begin{tabular}{lllllr}
\hline Year & ${ }^{137}$ Cs & $1{ }^{106}$ Ru & ${ }^{90}$ Sr & $\begin{array}{c}\text { Trans } \mathbf{~} \\
\text { Alpha }\end{array}$ & ${ }^{3} \mathbf{H}$ \\
\hline 1968 & 1.1 & 5.2 & 2.8 & 0.04 & 9700 \\
1969 & 1.4 & 1.7 & 3.1 & 0.2 & 12200 \\
1970 & 2.0 & 1.2 & 3.9 & 0.4 & 9500 \\
1971 & 0.93 & 0.50 & 3.4 & 0.05 & 8900 \\
1972 & 1.7 & 0.52 & 6.5 & 0.05 & 10600 \\
1973 & 2.3 & 0.69 & 6.7 & 0.08 & 15000 \\
1974 & 1.2 & 0.22 & 6.0 & 0.02 & 8600 \\
1975 & 0.62 & 0.30 & 7.2 & 0.02 & 11000 \\
1976 & 0.24 & 0.16 & 4.5 & 0.01 & 7400 \\
1977 & 0.21 & 0.20 & 2.7 & 0.03 & 6250 \\
1978 & 0.27 & 0.21 & 2.0 & 0.03 & 6292 \\
1979 & 0.24 & 0.13 & 2.4 & 0.03 & 7700 \\
1980 & 0.62 & 0 & 1.5 & 0.04 & 4554 \\
\hline
\end{tabular}

a To convert to tera becquerels, multiply curies by 0.037 . 
Table 4.4.2

RADIONUCLIDES IN THE CLINCH RIVER

1980

\begin{tabular}{|c|c|c|c|c|c|c|c|c|}
\hline I.ocalion & $\begin{array}{l}\text { Number of } \\
\text { sumples }\end{array}$ & Rangr & \multicolumn{5}{|c|}{$\begin{array}{l}\text { Concentration of Radionuclides of Primary Concern } \\
\left.\left.\text { [Units of } \mathrm{Bq} / \mathrm{L} \times 10^{-2} \text { and }(\mu \mathrm{Ci} / \mathrm{m}) \times 10^{-9}\right)\right]\end{array}$} & $\%$ \\
\hline $\begin{array}{l}\text { C-2 CRM } 23.1 \\
\text { Melion Hill }\end{array}$ & 4 & $\begin{array}{l}\text { Max } \\
\text { Min. } \\
\text { Avg. }\end{array}$ & $\begin{array}{l}0.85(0.23) \\
0.19(0.05) \\
0.41(0.11)\end{array}$ & $\begin{array}{l}0.67(0.18) \\
0.0(0) \\
0.26(0.07)\end{array}$ & $\begin{array}{l}1.0(0.27) \\
0.19(0.05) \\
0.63(0.17 \pm)\end{array}$ & $\begin{array}{l}0.85(0.23) \\
0.19(0.05) \\
0.41(0.11)\end{array}$ & $\begin{array}{l}3138(848) \\
2571(695) \\
2827(64)\end{array}$ & 0.07 \\
\hline $\begin{array}{l}\text { C-3 CRM its } \\
\text { Gallaher }\end{array}$ & 4 & $\begin{array}{l}\text { Max } \\
\text { Min. } \\
\text { Avg. }\end{array}$ & $\begin{array}{l}6.7(1.82) \\
0.67(0.18) \\
2.8 \quad(0.75)\end{array}$ & $\begin{array}{l}0.6(0.18) \\
0.0(0) \\
0.30(0.08)\end{array}$ & $\begin{array}{l}1.0(0.27) \\
0.19(0.05) \\
0.63(0.17 \pm)\end{array}$ & $\begin{array}{l}1.5(0.41) \\
0.33(0.09) \\
0.77(0.21)\end{array}$ & $\begin{array}{l}11962(3233) \\
2756(745) \\
5580(508)\end{array}$ & 0.16 \\
\hline $\begin{array}{l}\text { C-5 TRM S68 } \\
\text { Kingston Watet } \\
\text { Plant }\end{array}$ & 4 & $\begin{array}{l}\text { Max } \\
\text { Min. } \\
\text { Avg. }\end{array}$ & $\begin{array}{l}13.0(3.55) \\
0.33(0.09) \\
4.4(1.2)\end{array}$ & $\begin{array}{ll}6.7 & (1.8) \\
0.0 & (0) \\
0.26 & (0.07)\end{array}$ & $\begin{array}{ll}5.0 & (1.36) \\
0.33 & (0.09) \\
2.4 & (0.64)\end{array}$ & $\begin{array}{l}0.67(0.18) \\
0.19(0.05) \\
0.30(0.08 \pm)\end{array}$ & $\begin{array}{l}6867(1856) \\
2202(595) \\
3548(959)\end{array}$ & 0.11 \\
\hline
\end{tabular}

"Most restrictive concentration guide for each isotope used for calculating percent concentration guide. The method for cakulating percent of concentration guide for a known mixture of radionuclides is given in DOE Manual, Appendix 0524, Annex A." 
Table 4.4.3 Calculated Percent MPC of ORNL Liquid Radioactivity Releases at White Oak Dam, Intersêction of wite Oak Creek and $\mathrm{Cl}$ inct: River, and in the Clinch River Weter Below the Wouth of White Oak Creek - 1980

\begin{tabular}{lrcc}
\hline Month & wOD & $\begin{array}{r}\text { Intersection of } \\
\text { WOC \& CR }\end{array}$ & $\begin{array}{c}\text { Calculated } \\
\text { Value for } \\
\text { C. R. }\end{array}$ \\
\hline January & 87 & 25 & 0.2 \\
February & 102 & 44 & 0.3 \\
March & 94 & 36 & 0.7 \\
April & 104 & 37 & 0.3 \\
May & 100 & 27 & 0.2 \\
June & 65 & 10 & 0.04 \\
July & 61 & 7 & 0.03 \\
August & 80 & 4 & 0.03 \\
September & 45 & 5 & 0.02 \\
October & 77 & 4 & 0.05 \\
November & 69 & 23 & 0.1 \\
December & 111 & 14 & 0.3 \\
AvERAGE & 83 & & 0.2 \\
\hline
\end{tabular}

a Values WOD divided by dilution of Clinch River. 
Table 4.4.4 Annual Average Percent MPC of Beta Eaiters, Other than Tritiu, in the Clinch River

\begin{tabular}{lcccc}
\hline Year & CRe 23.1 & $\begin{array}{c}\text { Calculated } \\
\text { Value for C.R. }\end{array}$ & CRM $14.5^{b}$ & CRM 4.5 \\
\hline 1968 & 0.17 & 0.83 & 0.37 & 0.52 \\
1969 & 0.30 & 0.36 & 0.48 & 0.41 \\
1970 & 0.22 & 0.27 & 0.55 & 0.47 \\
1971 & 0.21 & 0.20 & 0.55 & 0.44 \\
1972 & 0.18 & 0.26 & 0.58 & 0.48 \\
1973 & 0.24 & 0.49 & 0.47 & 0.62 \\
1974 & 0.06 & 0.36 & 0.26 & 0.21 \\
1975 & 0.03 & 0.43 & 0.14 & 0.12 \\
1976 & 0.05 & 0.44 & 0.23 & 0.15 \\
1977 & 0.05 & 0.21 & 0.07 & 0.10 \\
1978 & 0.04 & 0.20 & 0.06 & 0.05 \\
1979 & 0.03 & 0.20 & 0.06 & 0.02 \\
1980 & 0.04 & 0.18 & 0.27 & 0.43 \\
\hline
\end{tabular}

Values are predominately from ${ }^{90} \mathrm{Sr}$.

b Values given for this location are based on analyses of water taken directly from the river.

c Values given for this location are calculated from the levels of radionuclides released from white Dak Dan and dilution provided by the Clinch River. 
Table 4.4.5 Annual Average Percent MPC of Tritium in the Clinch River

\begin{tabular}{ll}
\hline Year & CRM 20.8 \\
\hline 1968 & 0.07 \\
1969 & 0.11 \\
1970 & 0.05 \\
1971 & 0.04 \\
1972 & 0.04 \\
1973 & 0.07 \\
1974 & 0.04 \\
1975 & 0.06 \\
1976 & 0.07 \\
1977 & 0.05 \\
1978 & 0.05 \\
1979 & 0.04 \\
1980 & 0.03 \\
\hline
\end{tabular}

3 Values given are cal zulated from the level of waste released from thite Oak Dam and dilution provided by the $\mathrm{Cl}$ inch River. 
Table 4.4.6 Chemical Water Quality Data White Oak Dam - 1980

\begin{tabular}{|c|c|c|c|c|c|c|}
\hline \multirow{2}{*}{ Sibstance } & \multirow{2}{*}{$\begin{array}{l}\text { No. of } \\
\text { Samples }\end{array}$} & \multicolumn{3}{|c|}{ Concentration $(\mathrm{mg} / \mathrm{l})$} & \multirow{2}{*}{ Std. ${ }^{a}$} & \multirow{2}{*}{$\begin{array}{c}: 0 \\
\text { std. }\end{array}$} \\
\hline & & Maximun & Minimum & Average & & \\
\hline $\mathrm{Cr}$ & 10 & $<0.01$ & $<0.0 i$ & $<0.01$ & 0.05 & $<20$ \\
\hline $2 n$ & 10 & $<0.02$ & $<0.02$ & $<0.02$ & 0.1 & $<20$ \\
\hline $\mathrm{NO}_{3}(\mathrm{~N})$ & 10 & 9.8 & 0.01 & $4.6 \pm 2.2$ & 10 & 46 \\
\hline $\mathrm{Hg}$ & 12 & $<0.001$ & $<0.001$ & $<0.001$ & 0.005 & $<20$ \\
\hline
\end{tabular}

STennessee Stream Glidelines. 
Table 4.4.7 Chemical Water Quality Data Melton Hill Dam - 1980

\begin{tabular}{cccccccc}
\hline \multirow{2}{*}{ Substance } & $\begin{array}{l}\text { No. of } \\
\text { Samples }\end{array}$ & \multicolumn{2}{c}{ Concentration $(m g / \ell)$} & Maximum Minimum & Average & Std. & Std. \\
\hline $\mathrm{Cr}$ & 10 & $<0.01$ & $<0.01<<0.01$ & 0.05 & $<20$ \\
$\mathrm{Zn}$ & 10 & $<0.02$ & $<0.02$ & $<0.02$ & 0.1 & $<20$ \\
$\mathrm{NO}_{3}(\mathrm{~N})$ & 10 & 2.2 & 0.1 & $0.55 \pm 0.5$ & 10 & $<$ \\
$\mathrm{Hg}$ & 11 & $<0.001<0.001<0.001$ & 0.005 & $<20$ \\
\hline
\end{tabular}

${ }^{a}$ Tennessee Stream Guidelines. 
Table 4.4.8 National Pollutant Discharge Eliaination Systen (NPDES) Experience - 1980

\begin{tabular}{|c|c|c|c|c|}
\hline $\begin{array}{l}\text { Discharge } \\
\text { Point }\end{array}$ & $\begin{array}{l}\text { Eff luent } \\
\text { Paraneters }\end{array}$ & $\begin{array}{l}\text { Effluent } \\
\text { Daily } \\
\text { Average } \\
\text { og/l }\end{array}$ & $\begin{array}{l}\text { Linits } \\
\text { Oaily } \\
\text { Average } \\
\text { ag/L. }\end{array}$ & $\begin{array}{l}\text { Percentage } \\
\text { measurements } \\
\text { in Comliance }\end{array}$ \\
\hline $\begin{array}{l}\text { OndL } \\
\text { OOL } \\
\text { (White Oah Creek) }\end{array}$ & $\begin{array}{l}\text { Dissolved Oxyeen (nin.) } \\
\text { Dissolved Sollds } \\
\text { Oil and Grease } \\
\text { Chromiun (tota!) } \\
\text { pH (pH units) }\end{array}$ & $\begin{array}{l}5 \\
-- \\
10 \\
\cdots \\
--\end{array}$ & $\begin{array}{r}2000 \\
15 \\
0.05 \\
6.0-9.0\end{array}$ & $\begin{array}{r}95 \\
97 \\
100 \\
96 \\
98\end{array}$ \\
\hline $\begin{array}{l}002 \\
\text { (Melten Branch) }\end{array}$ & $\begin{array}{l}\text { Chroniu (total) } \\
\text { Dissolved Solids } \\
\text { Cil and Grezse } \\
\text { pH (pH units) }\end{array}$ & 10 & $\begin{array}{c}0.05 \\
2000 \\
15 \\
6.0-9.0\end{array}$ & $\begin{array}{r}98 \\
92 \\
100 \\
100\end{array}$ \\
\hline $\begin{array}{l}\text { 003 } \\
\text { (Main Saritary } \\
\text { Treatment racility) }\end{array}$ & $\begin{array}{l}\text { Amonia (K) } \\
\text { BOD } \\
\text { Chlorine Residual } \\
\text { Fecal Coliform Bact. } \\
\text { (no./100 ai) } \\
\text { pH (pH units) } \\
\text { Suspended Solids } \\
\text { Settleable Solids } \\
\text { (Et/l) }\end{array}$ & $\begin{array}{c}\cdots \\
\cdots \\
200^{2} \\
\cdots \\
\cdots \\
\cdots\end{array}$ & $\begin{array}{c}5 \\
2 n \\
0.5-2.8 \\
400 \\
6.0-9.0 \\
30 \\
0.5\end{array}$ & $\begin{array}{r}29 \\
83 \\
93 \\
100 \\
100 \\
89 \\
98\end{array}$ \\
\hline $\begin{array}{l}004 \\
\text { (7900 Area Sanitary } \\
\text { Treatment Facility) }\end{array}$ & $\begin{array}{l}\text { Bop } \\
\text { Chlorine Residual } \\
\text { Fecal Coliform Bace. } \\
\text { (no./100 ak) } \\
\text { pH (pH units) } \\
\text { Suspended Solids } \\
\text { Sereleable Solids } \\
\text { (al/L) }\end{array}$ & $\begin{array}{c}\cdots \\
\cdots \\
200^{2} \\
- \\
\cdots \\
\cdots\end{array}$ & $\begin{array}{c}30 \\
0.5-2.0 \\
400^{\circ} \\
6.0-9.0 \\
30 \\
0.5\end{array}$ & $\begin{array}{l}\text { No Discharges } \\
\text { Fron This } \\
\text { Facility }\end{array}$ \\
\hline
\end{tabular}

Monthly average.

bweekly average. 


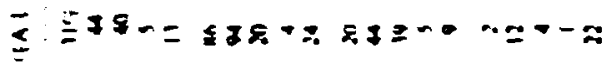

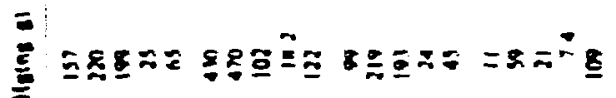

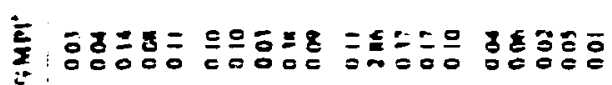

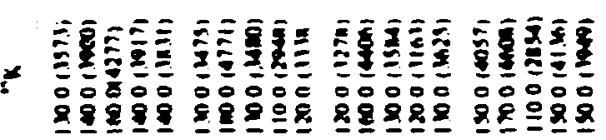

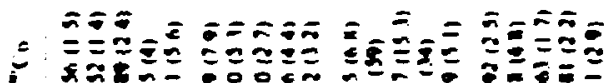

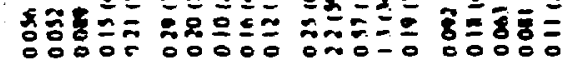

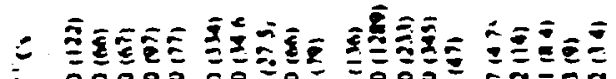
8488

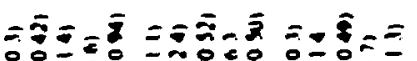

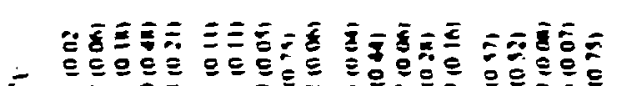

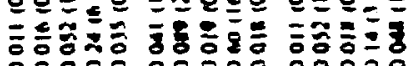

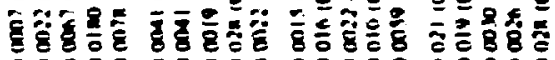
है $0000=0=000000000$

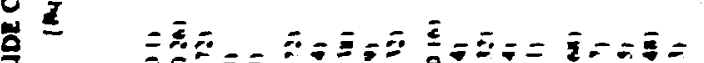

-

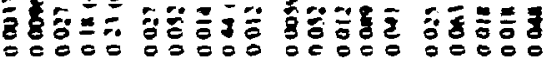

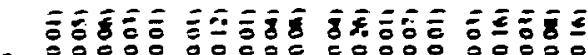

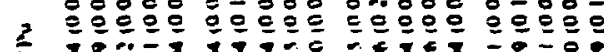

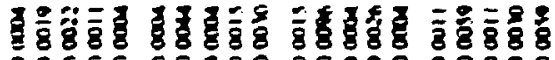

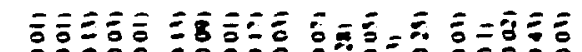
$\Rightarrow$ o

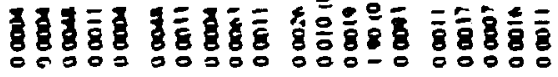

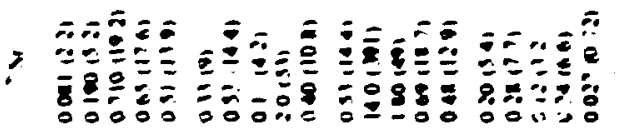

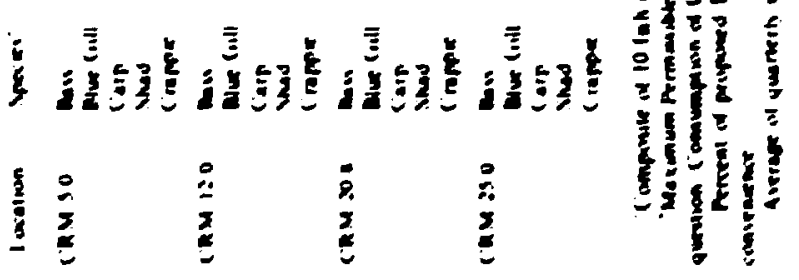


Table 4.5.1 External Gama Radiation Measurewents at Local Air Monitoring Stations - 1980

\begin{tabular}{|c|c|c|c|c|}
\hline $\begin{array}{l}\text { Station } \\
\text { Number }\end{array}$ & $\mu G y / h^{a}$ & $(\mathrm{urad} / \mathrm{h})$ & $\omega G y / y r^{b}$ & $(\mathrm{mrad} / \mathrm{yr})$ \\
\hline HP-1 & 0.25 & (25) & 2.20 & $(220)$ \\
\hline HP-2 & 0.60 & (60) & 5.26 & $(526)$ \\
\hline HP-3 & 0.08 & ( 8$)$ & 0.74 & $(74)$ \\
\hline HP - 4 & 1.60 & (160) & 13.99 & (1399) \\
\hline HP - 5 & 0.41 & (41) & 3.55 & (355) \\
\hline HP - 6 & 0.34 & (34) & 3.02 & $(302)$ \\
\hline HP -7 & 0.06 & (6) & 0.54 & $(54)$ \\
\hline HP-8 & 0.07 & (7) & 0.59 & (59) \\
\hline HP-9 & 0.11 & (11) & 0.96 & (96) \\
\hline HP-10 & 0.13 & (13) & 1.12 & $(112)$ \\
\hline HP-11 & 0.09 & (9) & 0.82 & $(82)$ \\
\hline$H P-12$ & 0.48 & (48) & 4.17 & $(417)$ \\
\hline HP-13 & 1.88 & (188) & 16.49 & $(1649)$ \\
\hline HP-14 & 0.11 & (11) & 0.96 & (96) \\
\hline HP-15 & 0.11 & (11) & 0.98 & (98) \\
\hline HP-16 & 0.08 & ( 8 ) & 0.70 & $(70)$ \\
\hline HP-17 & 0.10 & (10) & 0.88 & $(88)$ \\
\hline HP- 18 & 0.08 & ( 8 ) & 0.68 & $(68)$ \\
\hline HP-19 & 0.13 & (13) & 1.11 & (i11) \\
\hline HP - 20 & 0.10 & (10) & 0.89 & $(89)$ \\
\hline HP-21 & 0.08 & ( 8 ) & 0.74 & $(74)$ \\
\hline HP- 22 & 0.11 & (11) & 0.96 & $(96)$ \\
\hline Average & 0.31 & $(31)$ & 2.78 & $(278)$ \\
\hline
\end{tabular}

Average of two samples.

b Calculated assuming that an individual remained at this point for 24 hours/day for the entire year. 
Table 4.5.2 External Gamma Radiation Moasurements - 1980

\begin{tabular}{|c|c|c|c|c|c|c|}
\hline \multirow{2}{*}{$\begin{array}{l}\text { Station } \\
\text { Number }\end{array}$} & \multirow{2}{*}{ Location } & \multirow{2}{*}{$\begin{array}{l}\text { Number of } \\
\text { Measurnments } \\
\text { Taken }\end{array}$} & \multicolumn{4}{|c|}{ Background } \\
\hline & & & $\omega G y / h$ & $(\mathrm{\mu rad} / \mathrm{h})$ & $m G y / y r$ & $(\mathrm{mrad} / \mathrm{yr})$ \\
\hline
\end{tabular}

\section{Perimeter Stations}

\begin{tabular}{|c|c|c|c|c|c|c|}
\hline||$P-j \mid$ & Kerl Hollow liate & 12 & 0.083 & $(8,3)$ & 0.73 & (73) \\
\hline HP-32 & Midway Gate & 11 & 0.097 & $(9.7)$ & 0.85 & (85) \\
\hline HIP -33 & Gallaher Gate & 12 & 0.078 & $(7.8)$ & 0.68 & $(68)$ \\
\hline $14 \mathrm{P}-34$ & White Oak Dam & 12 & $n .160$ & $(16,0)$ & 1.40 & $(140)$ \\
\hline$H+35$ & Blair Gate & 11 & 0.076 & $(7.6)$ & 0.67 & $(67)$ \\
\hline$H P-36$ & Turnpike Gate & 11 & 0.073 & $(7.3)$ & $n .64$ & (64) \\
\hline IIP-37 & Hickory Creek Bend & 10 & 0.089 & $(8,9)$ & 0.78 & $(78)$ \\
\hline HP - 38 & East of EGCR & 12 & 0.080 & $(8 . c)$ & 0.70 & $(70)$ \\
\hline $\mathrm{HP}=39$ & Townsite & 12 & 0.073 & $(7,3)$ & 0.64 & (64) \\
\hline Averag & & & 0.090 & $(9.0)$ & 0.79 & (79) \\
\hline
\end{tabular}

Remote Stations

$\begin{array}{ll}\text { HP-51 } & \text { Norris Dam } \\ \text { HP-52 } & \text { Loudoun Dam } \\ \text { HP-53 } & \text { Douglas Dam } \\ \text { HP-55 } & \text { Wates Bar Dam } \\ \text { HP-56 } & \text { Great Falls Dam } \\ \text { HP-57 } & \text { Dale Hollow Dam } \\ \text { HP-58 } & \text { Knoxville }\end{array}$

054

(5.4)

0.47

(47)

0.073

(7.1)

0.62

(62)

2

$(7.3)$

0.64

(64)

HIP -55

HP -57

0.062

$(6.2)$

0.54

(54)

HP - 58

Knoxville

0.097

$(8.0)$

0.70

$(70)$

0.102

$(9.7)$

0.85

(85)

Average

0.077

$(7.7)$

0.67

(67)

See Fig. 4.1.3.

b see Fig. 4.1.4. 
Table 4.5.3 External Gama Radiation Measurements Along the Perineter of the DOE - Oak Ridge Controlled Area - 1980

\begin{tabular}{lllll}
\hline Location $^{\mathrm{a}}$ & $\mu G y / h$ & $(\mu \mathrm{rad} / \mathrm{h})$ & mGy/yr & $(\mathrm{mrad} / \mathrm{hr})^{\mathbf{b}}$ \\
\hline HP-60 & 0.12 & $(12.0)$ & 1.05 & $(105)$ \\
HP-61 & 0.17 & $(16.7)$ & 1.46 & $(146)$ \\
HP-62 & 0.30 & $(30.2)$ & 2.65 & $(265)$ \\
HP-63 & 0.60 & $(60.0)$ & 5.26 & $(526)$ \\
HP-64 & 0.36 & $(35.6)$ & 3.12 & $(312)$ \\
HP-65 & 0.33 & $(33.4)$ & 2.93 & $(293)$ \\
HP-66 & 0.34 & $(34.0)$ & 2.93 & $(298)$ \\
HP-67 & 0.22 & $(21.9)$ & 1.92 & $(192)$ \\
HP-68 & 0.13 & $(12.7)$ & 1.12 & $(112)$ \\
HP-69 & 0.10 & $(10.7)$ & 0.94 & $(94)$ \\
\hline
\end{tabular}

a See Fig. 4.1.8.

balculated assuming that an indivadual remined at this point for the entire year. 
Tabke 4.6.1

RADHOACTIVITY IN SOIL SAMPLES FROM PERIMETER AND REMOTE MONITORING STATIONS I90

[Units of Bq kg ai.d ( $\rho$ Ci g)-Dñ Weight]

\begin{tabular}{|c|c|c|c|c|c|c|c|}
\hline $\begin{array}{l}\text { Sampling } \\
\text { l.ocation }\end{array}$ & "Sr & "Cs & $\because 4 \mathrm{C}$ & $\because n$ & $\because \boldsymbol{l}$ & $\therefore$ Pu & 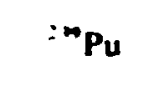 \\
\hline \multicolumn{8}{|c|}{ Perimeter" } \\
\hline HP-3I & $7.4(0.2)$ & $56(1.5)$ & $26(0.7)$ & $16(0.43)$ & $6.7(0.18)$ & C.07 (0.002) & $0.7(0.02)$ \\
\hline HP-32 & $22(0.6)$ & $63(17)$ & $4(1.2)$ & $2.2(0.06)$ & $24(0.66)$ & $0.07(0.002)$ & $0.7(0.02)$ \\
\hline HP-33 & $11(0.3)$ & $89(2.4)$ & $15(0.4)$ & $0.7(0.02)$ & 1110.29 & $0.1(0.003)$ & $1.1(0.03)$ \\
\hline HP-34 & $7.4(0.2)$ & $33(0.9)$ & II (0.3) & $0.7(0.02)$ & $8.5(0.23)$ & $0.07(0.002)$ & $0.37(0.01)$ \\
\hline HP-35 & $7.1(0.2)$ & $48(1.3)$ & $19(0.5)$ & $0.7(0.02)$ & $13(0.35)$ & $0.04(0.001)$ & $0.37(0.0)$ \\
\hline HP-36 & $7.4(0.2)$ & $52(1.4)$ & $11(0.3)$ & $1.1(0.03)$ & $8.9(0.24)$ & $0.04(0.001)$ & $0.7(0.02)$ \\
\hline HP-37 & $7.4(0.2)$ & $22(0.6)$ & $22(0.6)$ & $3(0.08)$ & $12(0.33)$ & $0.1(0.003)$ & $0.37(0.0)$ \\
\hline HP-38 & $7.4(0.2)$ & $41(1.1)$ & $11(0.3)$ & C.37(0.01) & $8.9(0.24)$ & $0.04(0.001)$ & $0.37(0.01)$ \\
\hline HP-39 & II (0.3) & $81(2.2)$ & $28(0.7)$ & $1.5(0.04)$ & $15(0.41)$ & $0.04(0.001)$ & $1.1(0.03)$ \\
\hline Average & II (0.3) & $56(1.5)$ & $22(0.6)$ & $3.0(0.08)$ & 1210.331 & $0.07(0.002)$ & $0.7(0.02)$ \\
\hline \multicolumn{8}{|c|}{ Remolé } \\
\hline HP-5I & $12(0.32)$ & $37(1.0)$ & $19(0.51)$ & I.I (0.03) & IS $(0.41)$ & $0.04(0.001)$ & $1.1(0.03)$ \\
\hline HP-S2 & $8.5(0.23)$ & $70(1.9)$ & $12(0.32)$ & $0.7(0.02)$ & $11(0.30)$ & $0.04(0.001)$ & $0.7(0.02)$ \\
\hline HP-53 & II (0.30) & $41(1.1)$ & I8 (0.49) & $2.6(0.07)$ & $15(0.41)$ & $0.0410 .0011)$ & 0.3710 .01 \\
\hline HP-5S & $31(0.84)$ & $56(1.5)$ & If (0.38) & $0.7(0.02)$ & $12(0.32)$ & $0.07(0.002)$ & $(.1(0.03)$ \\
\hline HP-S6 & $18(0.89)$ & $59(1.6)$ & $16(0.4 .3)$ & $0.7(0.02)$ & $14(0.38)$ & $0.04(0.001)$ & $0.7(0.02)$ \\
\hline HP-57 & $19(0.51)$ & $(30(3.5)$ & $2+(0.65)$ & 1510.04 & $20(0-54)$ & $0.1(0.003)$ & $1.5(0.04)$ \\
\hline & $5.2(0.14)$ & $56(1.5)$ & $15(0.41)$ & I I (0.03) & 1210.321 & 0.0410 .0011 & $0.7(0.02)$ \\
\hline Alerage & $15,0.401$ & $63(1.7)$ & $17(0.46)$ & 0.7 (7.02) & $14(0.3 x)$ & $0.0 \times 10.001$ & $07(0.02)$ \\
\hline
\end{tabular}

'See Figures 4.1 .3 and 4.1 .4 .

Average of ino samples.

One sampk 
Table 4.6.2

RADIOACTIVITY IN GRASS SAMPLES FRON. PERIMETER AND REMOTE MONITORING STATIONS $19 \%$

[Bq kg ( $($ C: 8$)$-Dry Weighi]

\begin{tabular}{|c|c|c|c|c|c|c|c|c|}
\hline $\begin{array}{l}\text { Sampline } \\
\text { location }\end{array}$ & Be & $" S r$ & $" C$ & $:$ "vu & $\because P u$ & $\because 11$ & $" 11$ & $\therefore 41$ \\
\hline \multicolumn{9}{|c|}{ Perimeter ${ }^{\wedge}$} \\
\hline HP.SI & $629(17)$ & $26(0,7)$ & $3.7(0.11$ & $0.07(0.002)$ & $0.04(0.001)$ & $1.9 \quad(0.05)$ & $0.59(0.016)$ & $4.1(0.11)$ \\
\hline HP-.12 & $444(12)$ & $22(0.6)$ & N() & $0.07(0.002)$ & $0.04(0.001)$ & $0.37(0.10)$ & $0.48(0.01 .3)$ & $12(0.3 .3)$ \\
\hline$H P^{3}-31$ & $185(5)$ & $44(1.2)$ & $3.7(0.1)$ & $0.04(0.001)$ & $0.04(0.001)$ & $1.1(0.0 .1)$ & $0.19(0.005)$ & $1.5(0.0 \times)$ \\
\hline HP-.14 & $294(8)$ & $41(1.1)$ & $7,4(0.2)$ & $0.07(0.002)$ & $0.04(0.001)$ & $0.74(0.02)$ & $0.22(0.006)$ & $1.1(0.0 .3)$ \\
\hline HP-.35 & $\operatorname{Mnn}(18)$ & $311(0.8)$ & $.7 .7(0.1)$ & $0.04(0.001)$ & $0.04(0.001)$ & $1.1(0.0 .3)$ & $0.26(0.007)$ & 2.610 .07 \\
\hline HP. .36 & $111(x)$ & $.30(0.8)$ & $V()$ & $0.04(0.001)$ & $0.04(0.001)$ & $1.1(0.0 .1)$ & $1.2(0.03 .3)$ & $1.5(0.04)$ \\
\hline HP..17 & $370(10)$ & is $(0.4)$ & $.7(0.1)$ & $0.04(0.001)$ & $0.04(0.001)$ & $0.74(0.02)$ & $0.1 /(0.00 .1)$ & $1.1(0.03)$ \\
\hline HP-.18 & $259(7)$ & $19(0.5)$ & $N(1)$ & $0.04(0.001)$ & $0.04(0.001)$ & $0.37(0.01)$ & $0.11(0.003$ & $1.1(0.0 .3)$ \\
\hline HP..19 & 559 (15) & $26(0.7)$ & $3.7(0.1)$ & $0.04(0.001)$ & $0.04(0.001)$ & $1.5(0.04)$ & $0.19(0.005)$ & $2.6(0.07)$ \\
\hline Average & $\$(1)(11)$ & $.30(0 . K)$ & $.3 .7(0.1)$ & $0.04(0.001)$ & $0.04(0.001)$ & $1.5(0.04)$ & $0.37(0.01)$ & $.0(0.08)$ \\
\hline \multicolumn{9}{|c|}{ Remote' } \\
\hline HP-SI & & $7.4(0.2)$ & ND & $0.04(<0.001)$ & $0.01 \quad(<0.000 .3)$ & $0.74(0.02)$ & $0.11(0.002)$ & $0.74(0.02)$ \\
\hline HP.S2 & & $19(0.5)$ & $2.2(0.06)$ & $0.0 \times(0.001)$ & $0.007(<0.0002)$ & $0.37(0.01)$ & $0.15(0.004)$ & $0.17(0.01)$ \\
\hline HP.S3 & & $11(0.2)$ & $4.1(1.11)$ & $0.04(0.001)$ & $0.007(0.0002)$ & $1.5(0.04)$ & $0.19(0.005)$ & $1.5(0.04)$ \\
\hline HP.S5 & & $11(0.3)$ & $2.2(0.06)$ & $0.07(0.002)$ & $0.04 \quad(<0.0011)$ & $0.74(0.02)$ & $0.48(0.013)$ & $1.1(0.0 .3)$ \\
\hline HP.56 & & $26(0.7)$ & $4.1(0.11)$ & $0.04(0.001)$ & $0.007(<0.0002)$ & $0.74(0.02)$ & $0.41(0.011)$ & $0.74(0.02)$ \\
\hline HP.\$7 & & $22(0.6)$ & ND & $0.04(0.001)$ & $0.007(<0.0002)$ & $0.37(0.01)$ & $0.52(0.014)$ & $1.5(0.04)$ \\
\hline HP-SK & & $7.4(0.2)$ & NII & $0.04(0.001)$ & $0.02(<0.0006)$ & $0.37(0.01)$ & $0.30(0.008)$ & $0.37(0.01)$ \\
\hline Average & & $15(0.4)$ & $.13(0.09)$ & $0.04(00.001)$ & $0.01(<0.0004)$ & $0.74(0.02)$ & $0.10(0.008)$ & $0.74(0.02)$ \\
\hline
\end{tabular}

See Figures $4.1,3$ and $4,1.4$

Average of two sumples.

One sumple.

Not detectable. 
Table 4.7.1 ${ }^{137} \mathrm{Cs}$ Concentration in Deer Samples - 1980
(pCi/kg Wet weight)

\begin{tabular}{|c|c|c|}
\hline Sample Number & Muscle & liver \\
\hline 1 & 10 & 43 \\
\hline 2 & 50 & $<10$ \\
\hline$j$ & $<10$ & $<10^{b}$ \\
\hline 4 & $2 ?$ & 15 \\
\hline 5 & $<10$ & $<10$ \\
\hline 6 & $<10$ & -10 \\
\hline 7 & $<10$ & $\because 10$ \\
\hline 8 & 10 & $<10$ \\
\hline 9 & 27 & $<10$ \\
\hline 10 & 41 & $=10$ \\
\hline 11 & 27 & 1: \\
\hline 12 & 68 & 38 \\
\hline 13 & 60 & 30 \\
\hline 14 & $\div 10$ & $<10$ \\
\hline 15 & $<10$ & $\therefore 10$ \\
\hline 16 & 78 & 15 \\
\hline 17 & 103 & $=0$ \\
\hline 18 & 24 & $<10$ \\
\hline 19 & 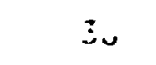 & -10 \\
\hline
\end{tabular}

${ }^{\mathrm{a}}$ To convert to $\mathrm{Bq} / \mathrm{kg}$, multiply by 0.037 .

${ }^{b}$ This liver sample contained $18 \mathrm{pCj} / \mathrm{kg}$. 
ORNL -OWG 79-14806

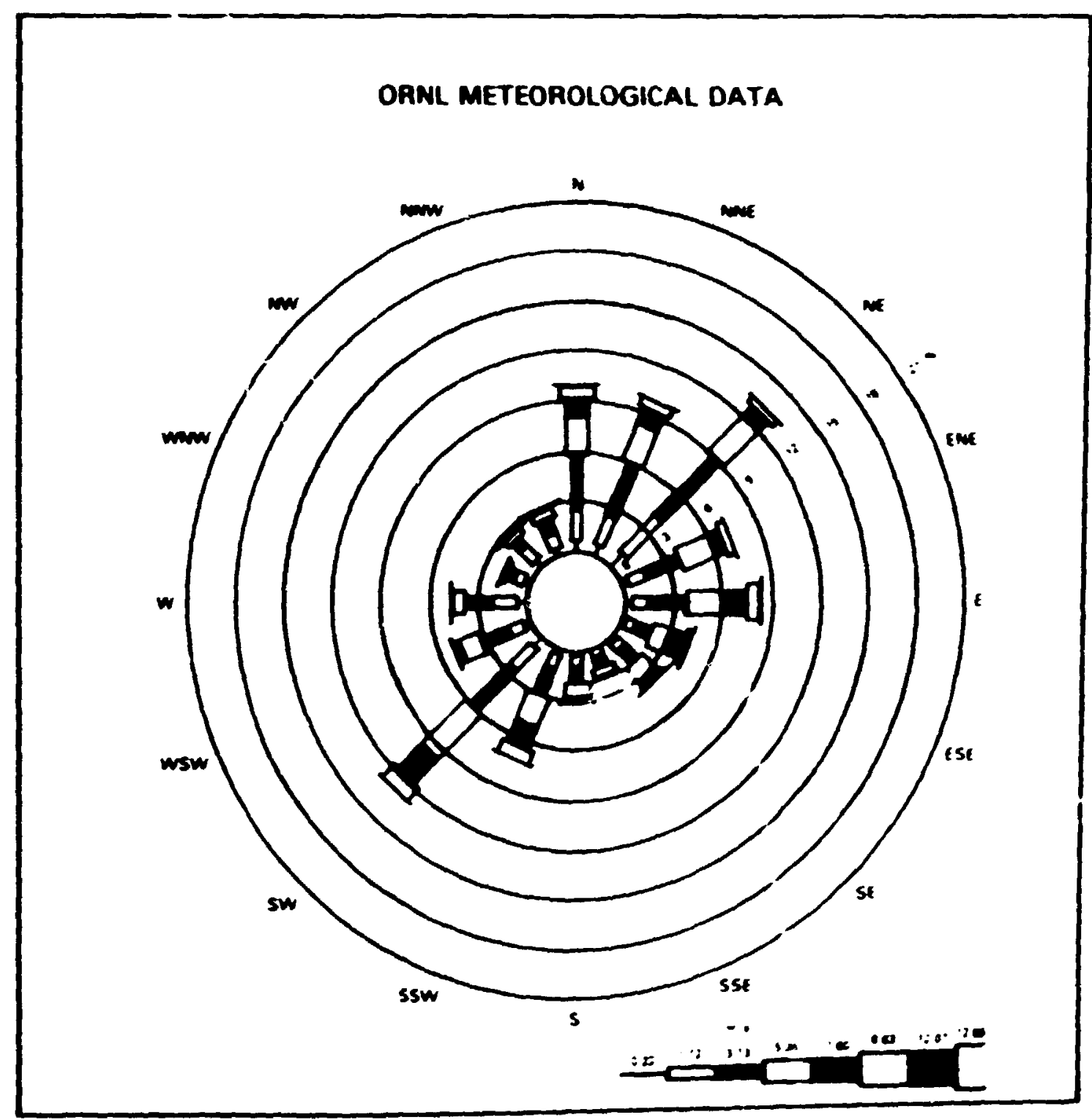

Fig. 4.8.1 Meteorological Data for the Oak Ridg Reservation 


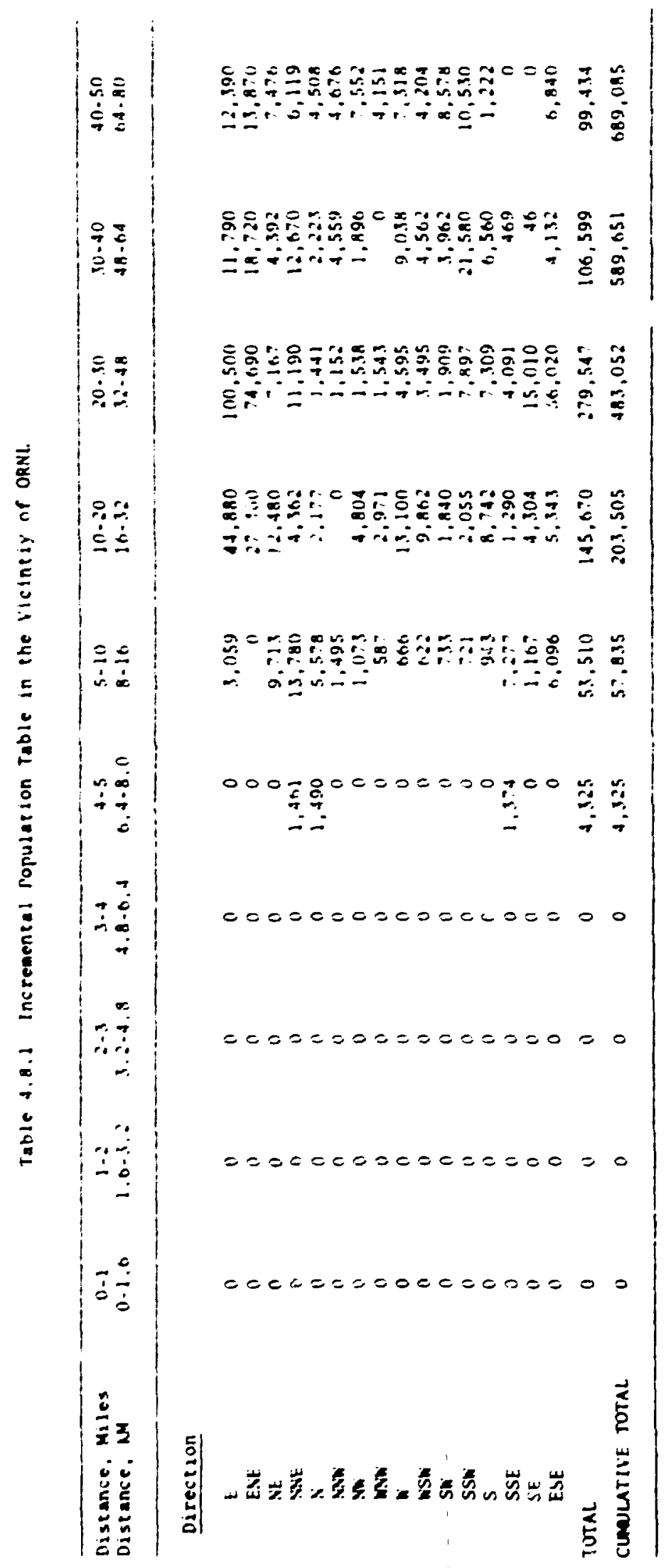


Table 4.8.2 Summary of the Estimated Radiation Dose to an Adult Individual During 1980 at locations of Maximum Exposure

\begin{tabular}{|c|c|c|c|c|}
\hline \multirow{2}{*}{ Pathway } & \multirow{2}{*}{ Location } & \multicolumn{3}{|c|}{ Dose uSv (millirem) } \\
\hline & & Total & Body & Critical Organ \\
\hline $\begin{array}{l}\text { Gaseous Effluents } \\
\text { Inhalation plus direct radiation } \\
\text { from air and ground }\end{array}$ & Nearest resident to site bounuiury & 18 & $(1.8)$ & $\operatorname{l(16}(16,6)(1$ ung $)$ \\
\hline Terrestrial food chains & Milk sampling stations $\left({ }^{90} \mathrm{Sr}\right)$ & 0.2 & $(0.02)$ & $1 !(1.5)$ (bone) \\
\hline $\begin{array}{l}\text { Liquid Ef wents } \\
\text { Aquati food chains }\end{array}$ & Clinch-Tennesse River System $\left({ }^{90} \mathrm{Sr}\right)$ & 11 & $(1.1)$ & $\$ 30(5.3)$ (bone) \\
\hline Drinking water ${ }^{2}$ & Kingston, Tennessee $\left({ }^{90} \mathrm{Sr}\right)$ & 1.5 & $(0.15)$ & e.t $(6.6)$ (hone) \\
\hline $\begin{array}{l}\text { Direct radiation along water, } \\
\text { shores, and mud flats }\end{array}$ & $\begin{array}{l}\text { Downstream from white Oak Creek } \\
\text { near experimental CS ficld plots }\end{array}$ & $6:$ & $(6.2)$ & b. $(6.2)$ (total hody) \\
\hline
\end{tabular}

a Based on the analysis of raw (unprocessed) water.

bAssuaing a residence time of $240 \mathrm{hr} / \mathrm{rr}$.

NOTE: Average background cotal body dose in the U.S. is $106 \mathrm{mrem} / \mathrm{yr}$. 
Table 4.9.1 Environmental Monitoring Samples - 1980

\begin{tabular}{|c|c|c|}
\hline Sample Type & Type of Analyses & $\begin{array}{l}\text { Number of } \\
\text { Samples }\end{array}$ \\
\hline $\begin{array}{l}\text { Honitoring Network } \\
\text { Air Filters }\end{array}$ & Gross Alpha, Gross Beta & 1,560 \\
\hline $\begin{array}{l}\text { Monitcring Network } \\
\text { Air Filters }\end{array}$ & $\begin{array}{l}\text { Gamma Spectrometry, } \\
\text { Wet Chemistry }\end{array}$ & 12 Groups \\
\hline $\begin{array}{l}\text { Gummed Paper } \\
\text { Fallout Tray: }\end{array}$ & Autoradiogram & 676 \\
\hline $\begin{array}{l}\text { Gumed Paper } \\
\text { Fallout Trays }\end{array}$ & Long Lived Activity Count & 1,560 \\
\hline Charcoal Cartridge & ${ }^{131} I$ & 985 \\
\hline Fish & $\begin{array}{l}\text { Radiochemical, Gamma } \\
\text { Spectrometry }\end{array}$ & 38 Groups \\
\hline Rainwater & Gross Beta & 964 \\
\hline Raw Milk & ${ }^{131} \mathrm{I},{ }^{90} \mathrm{Sr}$ & 360 \\
\hline $\begin{array}{l}\text { White Oak Dam } \\
\text { Effluent }\end{array}$ & $\begin{array}{c}\text { Gross Beta, Radiochemical, } \\
\text { Gamma Spectrometry }\end{array}$ & 410 \\
\hline White Oak Creek & $\begin{array}{c}\text { Gross Beta, Radiochemical } \\
\text { Gamma Spectrometry }\end{array}$ & 238 \\
\hline Clinch River Water & $\begin{array}{l}\text { Radiochemical, Gamma } \\
\text { Spectrometry }\end{array}$ & 54 \\
\hline Potable Water & $\begin{array}{l}\text { Radiochemical, Gamma } \\
\text { Spectromet ry }\end{array}$ & 8 \\
\hline Soil Samples & $\begin{array}{l}\text { Gamma Spectrometry, } \\
\text { Wet-Chemistry }\end{array}$ & 32 Grnups \\
\hline Grass Samples & $\begin{array}{c}\text { Gamma Spectrometry, } \\
\text { Wet-Chemistry }\end{array}$ & 32 Groups \\
\hline Deer Samples & Gamna Spectrometry & 38 \\
\hline TLDs & External Gamma Radiation & 144 \\
\hline Hi Vols & Particulates & 143 \\
\hline Tritiun & HTO & 42 \\
\hline
\end{tabular}




\subsection{RADIATION AND SAFETY SURVEYS}

\subsection{Laboratory Operations Monitoring}

During 1980 members of the Radiation and Safety Surveys Section provi: $>d$ radiation surveillance services to the research and operating groups is support of effoits to keep personnel exposures, concentrations of airborne radioactivity, ano levels of surrace contamination well within permissible limits. This assistance in wping with the problems associated with radiation work wa: provided through seminars, safety meetings, and discussions with those planniug, supervising, and performing the work. Following is a briaf review of some of the more salient events in which they participated.

\subsubsection{HRLAL, Cell Exhaust Filter Reple ment, Building 2026}

Over a period oi $\sim 15$ years, a gradual. increase in the pressure drop across the HRLAL cell exhaust roughing filters necessitated their replacement. Replacements for the 105 :ilter units were no longer cormercially available. Duilding 2025, supervision decided to replace the 21 roughing filter racks with new racks, fabricated at ORNL. Each new rack received a commercially available filter that replaced five of the old fiiter units.

Personnel of the Analytical Chemistry, Plant and Eluipment, and Industrial Safety and Appiied Health Physics Divisions collaborated in planning for and developing detailed written procedures for the replacement. Radiation measurements were mare which aided in the design of the used Filter containment boxes and a reusable shie?. Readings at several inches from individual filter units were in the range of $n 10$ to $20 \mathrm{mGy} / \mathrm{h}(2$ to $3 \mathrm{rad} / \mathrm{h})$. Sross alpha contamination was also indicated. Remote tools kere designed and fabricated which eliminated the need for personnel to enter the grossly contaminated $f^{\prime} 1$ ter pits and p'rmitted removal, as a unit, of each old filter rack and the five used filters the ${ }^{2}$ in. All filter frames and filters were successfully reflaced over a four-duy period with no personnel dose exceeding $1 \mathrm{mSv}$ (100 mrem) and with no release of radioactive contamination.

\subsubsection{Bulk Shielding Reactor, Building 3010}

The Bulk Shielding Reactor, operated by the Operations Division, is utilized primarily by research divisions at ORNL for brief irradiation of samples. Ons such project, related to the Coal Gasification Program, uses this facility to irradiate coal tar samples so that multi-element analyses can be performed. Tnese samples are inserted and remcved from the core with health physics surveillance and with cauticil, :esulting in no appreciable radiation exposures to personnel. 


\subsubsection{Radiochemical Pilot Plant Poerations, Building 3019}

During the year, Pilot Plant participation in two programs was completed and considerable attention was given to equipment maintenance, to decontamination and decomissioning of several facilities, and to preparation for several new programs. In general, control of personnel exposures and radioactive materials was very good. The few unusual occurrences which took place were of a very minor nature. Approxinately one hundred-forty Radiation hork Permits were certified for Pilot rlant operations.

Participation in the Argonne National Laboratory Zero Power Reactor Program terminated in February with the final shipwent of ${ }^{23}{ }^{2} \mathrm{U}_{3} \mathrm{O}_{8}-$ loaded packets. The Light Water Boiling Reactor Progran participation was concluded after a series of dissolver runs, which resulted in recovery of $\sim 700 \mathrm{~kg}$ of thorium and $\sim 18 \mathrm{~kg}$ or $233 \mathrm{U}$ from "scrap pellets" generated by Bettis Atomic Power Laboratory.

Equipment maintenance included a thorough, extensive testing of process instrumentation and instrumencation lines between the Penthouse and process vessels in the cells and pipe tunnel. Many leaks were locited and repaired.

Decomm s sioning of the Room 303A, Sol-gel $\left({ }^{233} \mathrm{U}, 235 \mathrm{U}\right)$ Facility was initiated and decommissioning of the Room 211, High Alpha Development laboratory $\left({ }^{233} \mathrm{U}, 239 \mathrm{Pu}\right)$, was completed. After removal of highly contaminated equipment and gross alpha contamination from the Room 211 glove boxes, the boxes were contained and consigned to the solid waste storage area. Room surfaces were cleaned of significant transferable contamination.

Room 209 was decommissioned as an analytical chemiciry laboratory and is being prepared for installation of glove boxes to be used in a plutonia-urania fue? developuent program. Contaminated equipment and floor surfaces were removed.

\subsubsection{CEUSP, Building 3019}

The Consolidated Edison Uranium Solidification Program (CEUSP) was initiated to solidify some 7,500 liters of solution containing a mixture of $233 \mathrm{U}$ and $235 \mathrm{U}\left(\sim 10^{3} \mathrm{~kg}\right.$ total $U$ ). The uranium was recovered from the Consolidated Edison Indian Point Reactor fuel and had been stored over ten years in the Thorium $f$-actor Uranium Storage Tank (TRUST) south of Building 3019. Pilot Plant Cell 3 will be utilized to solidify and encapsulate the uranium. Sealed containers will te stored in existing Cell \#4 storage wells. CEUSP site preparation included: drilling duct and piping ponetrations in Cell 3 walls; renoving the air duct between the Pelthousc and Cell 3 Plenum; and enlarging the Cells 3 and 4 Plenum (to be the CEIISP Control Room) by relocating the south wall and by removing the Cell "4 staicway enclosure. Alt these operations involved s-me potential for release of alpha contanination previously bonded to surfaces. 


\subsubsection{Decomissioning of Radiochenical Waste System, Building 3026-C}

Radiation and Safety Surveys personnel provided monitoring and surveillance for the decommissioning of the Radiochemical Waste Systen for Building 3926-C. The facility, originally used for the storage of radioactive waste solutions for the building, contained thirteen tanks and associated piping arranged in the shielded enclosure on two levels. Radiation levels, prior to draining and transfer of material in the tanks to the Intermeriate Level Waste System (ILW), ranged from $2 \mathrm{mGy} / \mathrm{h}$ $(0.2 \mathrm{rad} / \mathrm{h})$ at the top to $0.9 \mathrm{~Gy} / \mathrm{h}(90 \mathrm{rad} / \mathrm{h})$ at the side of one of the large tanks near the bottom of the enclosure. After extensive decontamination, careful planning, and the use of remote tools, all equipment and debris were removed and transferred to the Solid Waste Storage area. The maximum radiation levels on the tank packages sent to the burial ground were $5 \mathrm{mGy} / \mathrm{h}(\dot{u} .5 \mathrm{rad} / \mathrm{h})$. The empty enclosure required extensive decontamination to reduce the floor and walls to acceptable levels. Radiation levels on the floor ranged up to $0.2 \mathrm{~Gy} / \mathrm{h}(20 \mathrm{rad} / \mathrm{h})$. The final survey of the pit indicated readings of $0.35 \mathrm{mGy} / \mathrm{h}(35 \mathrm{mrad} / \mathrm{h})$ on the floor and a general background of $0.05 \mathrm{mGy} / \mathrm{h}(5 \mathrm{mrad} / \mathrm{h})$. The pit was filled with gravel, and a $15 \mathrm{~cm}$ cap of concrete was poured on the top to seal the pit. An appropriate marker was attached to the concrete to identify the project. Personnel exposure controls were effective and contamination was confined.

\subsubsection{Isotope Area Jperations, Building 3038, et al.}

Work in this area continued at about the same level as in the previous year. This consisted of the production, packaging, and shipping of radioisotopes for medical, industrial, alud experimental uses. Principal isotopes consisted of ${ }^{3} \mathrm{H},{ }^{67} \mathrm{GA},{ }^{75} \mathrm{Se},{ }^{85} \mathrm{Kr},{ }^{9} \mathrm{Sr},{ }^{137} \mathrm{Cs},{ }^{153} \mathrm{Gd}$, $192 \mathrm{Ir},{ }^{237} \mathrm{~Np},{ }^{4} 1_{\mathrm{Am}}$, and several isotopes of $\mathrm{Pu}$. The Research Macerials 'Laboratory continued the fabrication of dosimeters from varin's isotopes of uranium, neptunium, thorium, and plutonium. During the year over 2, ino packages of radioactive materials were shipped from the Laboratory. The monitoring of these packages assured that each was in complian:e with applicable Department of Transportation regulations.

One major operation involving the replacement of a window in a hot cell was completed in Building 3029. Readings exceeding $1 \mathrm{~Gy} / \mathrm{h}(100 \mathrm{rad} / \mathrm{h})$ inside the cell and 50 to $100 \mathrm{mGy} / \mathrm{h}(5$ to $10 \mathrm{rad} / \mathrm{h})$ at the cell door necessitated extensive decortanination before the window and a broken hoist could be moved. Contamination inside the cell was mainly due to ${ }^{90} \mathrm{Sr}$. After decontamination efforts and the use of local shielding consisting of plywood and lead sheets, the working background was reduced from $5 \mathrm{mGy} / \mathrm{h}$ to $20 \mathrm{mGy} / \mathrm{h}$ (500 mrad/h to $2 \mathrm{rad} / \mathrm{h}$ ). Approximately $60 \mathrm{Plant}$ and Equipment people workec inside the cell during this operation. Close surveillance monitoring by Health Physics personnel succeeded in keeping dose equivalents to all those involved within permissible limits. 


\subsubsection{Oak Ridge Research Reactor, Building 3042}

Radiation and Safety Surveys personnel assisted in the insertion and remoral of several experiments at the Oak Ridge Research Reactor Facility during 1980. One such experiment, the Pressure Vessel Simulator, is of some importance to the reactor safety program and is being conducted at the request of the Nuclear Regulatory Commission. The primary objective of the experiment is an improvement in the accuracy of predicting the remaining safe operating lifetime for light water pressure vessels currently in use. Reactor pressure vessel specimens will be irradiated in a controlled environment for a two-year period, after which radiation damage and changes in material properties will be analyzed and the effects assessed. During the insertion and removal of experiments such as this, per: onnel exposures were maintained at a small fraction of permissible limits, and contamination was successfully confined to established zoned areas.

\section{1 .8 Decomissioning of ${ }^{60} \mathrm{Co}$ Source, Building 4501, Room 206}

A ${ }^{60}$ Co irradiation unit ( 211 tera Bq [297 Ci]) was taken out of service and removed from Room 206 in preparation for its transfer to an off-site location. After all service lines were stripped from the outside of the unit, the source capsule vas drawn up into the movable shield. A modified lead plug was then inserted in the cavity below the capsule, secured in place, and the unit was transferred to a storage area by ORNL riggers.

Health Physics surveillance was provided for all phases of the operation and none of the personnel involved in the source manipulation received total doses in excess of $0.2 \mathrm{mSv}$ ( $20 \mathrm{mrem}$ ).

\subsubsection{Changing of Glove Box Windows, Building 4508, Room 136}

Industrial Safety and Applice Health Physics personnel providcd radiation monitoring assistance juring the changing of nine windows on five metallography glove boxes in the Ceramic Iucls Alpha Laboratory, Room 136, Building 4508.

The boxes were grossly contaminated on the inside, principally with uranium and plutonium isotopes. Prior to the windows being removed, the insides of the glove boxes were decontaminated and some equipment was removed through the bag-out ports. Repeated efforts in cleaning the toxes resulted in the contamination levels being reduced to $\sim 20,000 \mathrm{~d} / \mathrm{m}$ (paper towel smear). Two coats of Amercoat 33 were then applied to prevent the spread of contamination as windows were being removed.

Plastic work rooms were built around each window for removal of old glass and replacement of new. New gasket material was used at all glassto-box sealing surfaces. Protective clothing, including respiratory protection, was worn by all personnnel involved in the operation. The old vindows were placed in individual plywood boxes and transported to the solid waste storage area. 
The entire operation was completed without significant spread of contanination or personnel exposure exceeding daily limits.

5.1.10 Transuranium Research Laboratory (TRL), Building 5505

The TRL Industrial Safety and Applied Health Physics staff continued to provide protective technical support to experimental prograns involving the investigation of physical and chemical properties of transuranium elements. This activity included working directly with individual researchers in designing appropriate containment enclosures and procedures, assembling and disassembling apparatus, conducting sarious experiments, decontamination, and the disposal of radioactive wastes. In addition, they continued to function as building operators in charge of all aspects of the TRL ventilation and containment system. Also, two members of the staff assigned to this facility functioned as the Chemistry Division's RCO/DSO and alternate.

\subsubsection{Holifield Heavy Ion Facility, Building 6000}

Surveys were conducted duri'g initial testing phases of the Heavy Ion Facility in order to determine the location and magnitude of potential radiation hazards. Preliminiry calibration checks were also made on the $\gamma-n$ detectors which comprise a portion of the permissive entry inter lock system.

\subsubsection{Target Replacement, Oak Ridge Electron Linear Accel erator, Building 6010}

Continuou: health physics surveillance was provided during the replacement of a highly activated ORELA tantalum target. External exposures to personnel were kept at acceptable levels as a result of close adherence to as-low-as-reasonably-achievable (ALARA) principles.

\subsubsection{Building 6025}

The $300 \mathrm{KV}$ MFE Deuteron Accelerator was dismantled and relocated in Building 6010. Health physics coverage was present throughout the move in order to ensure the containment of ${ }^{3} \mathrm{H}$ contamination and minimize the attendant risk of internai deposition.

\subsubsection{Nuclear Safety Pilot Plant Operations, Building 7500}

The Nuclear Safety Pilot PIant conducted several experiments in which uranium metal was converted to $\mathrm{UO}_{2}$ by burning in order to simulate fuel aerosol narticles which might be generated in the unlikely event of an acciden: nvilving the fuel in fast reactors. Sampling studies were made of the resultant fallout and particle deposition on the bottom and sides of the modil containment vessel. Sodium metal burning experiments were also conducted in the same vessel. Radiation and conventional safety assistance was provided during these experiments which transpired without incident. 


\section{S.1.15 DOSAR Facility, Buildings 7709 and 7710}

Radiation hazard surveillance and technological assistance were provided for the research efforts at this unique facility where an unshielded reactor is used in dosimetry development and the study of biological effects of nuclear radiations. Two dosimetry intercomparisons, both international in scope, were conducted during the year. One was related co personnel dosimetry, the other to nuclear accident dosimetry. The progran to improve reactor material security systems continued but at a considerably reduced rate. The DOSAR reactor was also used to irradiate Threshold Detector Units in a study for the Industrial Safety and Applied Health Physics Division.

\subsubsection{High Flux Isotope Reactor (HFIR), Building 7900}

A new facility devoted to basic research on nuclei was installed and began operations at the HFIR. This is the Smali Angle Neutron Scattering (SANS) Facility and has both national and international participants involved in the research programs. Consultation and surveillance services were provided by Radiation and Safety Surveys personnel during the construction phase in regard to the need for shielding, as well as work area zoning requirements.

In addition, intensive surveillance was provided during routine reactor operations such as the loading and transfer of spent fuel elements, removal of experiments, and the handling of various highly radioactive sources. Reactor shutdown activities included the repair of some primary heat exchangers, the replacement or drive rods and rod seals, as well as various other operations in the reactor pool tank. These required especially close surveillance and stringent controls due to the high levels of radiation and contamination involved.

\subsubsection{Chemical Technology Operations, Building 7920}

A new charcoal filter "back-up" system was installed in a pit south of the TRU building. Radiation and Safety Surveys personnel were closely irivolved in both the planning and the installation of the systems tie-in with the existing hot off-gas line.

Further application of the ALARA concept was carried out with the installation of an elaborate, efficient neutron and gama shield for the glove box in Room 111. This should result in reduced personnel dose to those routinely working at this glove box. Improvements were also made in waste handling and partitioning to further reduce unnecessary exposure of personnel. Diligent planning ant surveillance attention was provided during operations, such as the repair of highly contaminated equipment and the preparation of intensel radioactive sources for shipment. 


\subsubsection{Modification to 86" Cyclotron, Building 9201-2}

Radiation and Safety Surveys personnel provided input to the plans for modification of the Operations Division's 86" Cyclotron. The "upzrade," if implenented as planned, has anong other objectives the reduction of radiation exposures sustained by operating persomel bringing the nore in line with the ALARA philosophy. Preparatory work, prior to the modifications, will result in modest exposures to mintenance personnel since it involves the removal of the activated dees and liner.

\subsubsection{Tank Fare Operation}

Close surveillance was provided for contractor (Rust) persomel during excavation work and installation of equipaent in conjunction with the Guinte Tank Sludge Renova) Project. This project, which will continue for several more months, will result in the transfer of highly contaminated sludge from the tank ram area to newly constructed storage tanks in Melton Valley.

\subsection{Ray and Microwave Safety Programs}

\subsubsection{Ray Program}

Routine surveys were made on approxinately $15 x$-ray units. Leakage on all units was within acceptable limits. Safety systeas were also cherked and found to meet ORNL standards. Two units, however, lacked the requisite fail-safe lights and measures were initj-_ed to bring these units into compliance.

\subsubsection{Microwave Program}

Five new microwave cooking oveils were checked for microwave leakage and interlock integrity. Appoximately 30 routine surveys were made on other units. Leakage on all ovens was within federal limits and no interlock failures were detected.

\subsection{Laundry Monitoring Facility}

Approximately 570,000 articles of wearing apparel and 214,000 articles such as mops, laundry bags, towels, etc., were monitored at the laundry during 1980. Appoximately five percent were found contaminated. Of 440,566 khaki garments monitored durino the year, only 64 were found contaninated.

A total of 4,525 full-face respirators and 5,296 canisters were monitored during the year. Of these, 118 masks and 254 canisters required further decontamination after the first cleaning cycle. 


\subsection{Radiation Incidents}

The term "radiation incident" is applied to classify an unexpected and undesirable operational occurrence involving radiation or radioactive materials and is further defined in Procedure 2.6 of the ORNL Health Physics Procedure Manual. There were five such occurrences in 1980. All were of minor significance. 


\subsection{INDUSTRIAL SAFETY AND SPECIAL PROJECTS}

Industrial Safety and Special Projects is responsible for developing and implementing accident prevention and loss management programs within the Laboratory. The staff of safety professionais provides consultation and assistance in industrial safety matters. The staff also participates in inspection and evaluation programs to assess the level of safety in various ORNL activities. The staff participates in a variety of safety-related activities, including developing safety policies and procedures; reviewing engineering drawings for safety content; and proviciing safety orientation and specialized safety education programs. They maintain a library of DOE-prescribed safety standards, safety reference material, and audio-visual aids. The Industrial Safety and Special Projects Section also provides Laboratory-wide on- and offthe-job safety promotion activities. The staff is involved in investigating, analyzing, classifying, and documenting injuries and accidental property losses. The safety staff also provides support to Construction Engineering in carrying out the construction safety program.

During 1980 the Laboratory completed the sixth consecutive year in which the goals set by UCC-ND Management for nrnvention of injuries were met or improved upon. Two disabling injuries or lost workday cases occurred during the year.

For the sixth straight year, the Laboratory earned the highest award of the National Safety Council. We also earned DOE's Award of Excellence and the Award of Honor.

\subsection{ORNL Safety Program Activities - 1980}

\subsubsection{Achievements}

1. National Safety Council's "Award of Honor."

2. Union Carbide Corporation's "Distinguished Safety Award."

3. Qualified for DOE's "Award of Excellence" for 1980.

\subsubsection{Action Plans}

1. Industrial Safety and Applied Health Physics' Action Plan developed for CY 1981.

2. ORNL's Safety Action Plan developed for CY 1981.

3. All Laboratory Divisions given instructions and required to submit Divisional Safety Action Plans for CY 1981.

\section{$6.1 . \vdots$ Promotional Efforts}

1. Central Safety Committee continued to meet monthly. Committee organized in October 1978.

2. Fifteen safety films purchased fur visual aid library. 
3. Pictures and slides prepared on all RIIs. Location of RIIs identified on area map.

4. Approximately 5000 ice scrapers with safety slogan distributed to personnel on request.

5. Personal Appointment Record Calendars with safety slogans distributed to personnel on request.

6. Large desk memo calendars with safety message available from stores.

7. Distribution of magazines and pamphlets concerning on- and offthe-job safety material.

8. Plant-wide distribution of safety billetins on subjects of general interest.

9. Five new procedures added to the safety manual and five procedures revised.

10. Amount of safety award value accumulated per employee during 1980 was $\$ 13.50$.

\subsubsection{Training}

1. Continuation of defensive driving course. The number of employees completing the course in 1980 was 219 . Appoximately $55 \%$ of the Laboratory's employees have completed the course.

2. The Supervisors' Development Program, a twelve-hour safety training course for supervisors, was obtained from the National Safety Council. During 1980, forty-one Plant and Equipment foremen completed the course and received certificates after passing the required examination.

\subsubsection{Audits and Appraisals}

1. Formal quarterly safety appraisals were conducted for each Laboratory division by the Industrial Safety staff.

2. The Laboratory received 1980 safety audits from:

a. Union Carbide Corporation - Nuclear Division apprajsal team.

b. DOE - Laboratory operations.

c. DOE - Construction.

\section{1 .6 OSHA}

1. A resurvey was made of ORNL and ORNL facilities at $Y-12$, aimed at bringing the Laboratory in compliance with OSHA standards. Modifications were made in a Conceptual Design Report submitted in 1976, as well as looking for additional items that might have been overlooked previously.

2. Work orders issued and records kept on OSHA expenditures of appoximately $\$ 130,000$ during 1980 . 


\subsubsection{Listing of Industrial Safety Department Representatives for Laboratory Divisions}

\section{Location $4500 S$}

A. D. Warden (4-6677)

Computer Sciences

Employee Relations

Finance \& Materials*

Operations

Solid State

R. E. Millspaugh (4-6680)

Chemical Technology

Environmental Sciences

Instrumentation \& Controls*

Metals \& Ceramics

Physics*
D. C. Gary (4-6678)

Analytical Chemistry

Chemistry*

Health

Health \& Safety Research

Plant \& Equipment

L. L. Huey (6-6792)

Energy*

Industrial Safety \& AHP*

Information *

Laboratory Protiction*

Quality Assurance \& Inspection*

T. J. Burnett (4-6683)

Engineering

Engineering Physics*

*New Assignments - 1/1/81

\subsection{Accident Analysis}

The injury statistics for ORNL for the period 1971-1980 are shown in Table 6.1.1. Included with this table are the formulas for determining lost workday statistics as contained in ANSI 216.4-1977.

The disabling injury history or lost workday cases for the past five years is shown in Table 6.1.2; and the disabling injury frequency rate since the inception of Union Carbide's contract as compared with NSC, DOE, and UCC is shown in Table 6.1.3.

Twelve ORNL divisions did not have a recordable injury or illness in 1980. Injury statistics by division are shown in Table 6.1.4.

Disabling injury accident-free periods for ORNL are shown in Table 6.1.5. From May 11, 1980, through December 31, 1980, the Labnratory accumulated over $5 \mathrm{mill}$ ion workhours wi thout a disabling injury.

Table 6.1.6, Figurc 6.1 .1 , and Table 6.1 .7 present ORNL injury data as to type, part of body injured, and nature of injury. 
A tabulation of the injuries for the four UCC-ND facilities is shown in Table 6.1.8.

Statistics on motor vehicle accidents, fires, and off-the-job injuries are shown in Tables 6.1.9,6.1.10, and 6.1.11. There was a significant decrease in the number of vehicle accidents during 1980, from 17 in 1979 to 6 in 1980 . The decrease in the accident rate was accomplished through a major emphasis being directed to the problem by management and the cooperation of all laboratory employees.

The number of off-the-job injuries reported for 1980 was 63 . The number reported in 1979 was 72 . Constant effort is being applied by the Safety Department and by all levels of Laboratory management in seeking ways to improve this important phase of the safety program. The two off-the-job fatalities that occurred during the year were the result of a two-car vehicle accident.

\subsection{Summary of Disabling Injuries}

The following are summaries of two disabling injuries experienced at ORNL in 1980 .

$$
\text { Date of njury - April 16, } 1980
$$

A power equipment operator slipped and fell to the ground while stepping down from an excavator. He sustained a fractured vertebrae. Time loss: 80 days.

Date of Injury - May 10, 1980

An engineer, assigned to ORNL, was walking across a recently waxed floor in Building 9204-1 $(Y-12)$ when he slipped and fell, fracturing his left kneecap. Time loss: 67 days.

\subsection{Safety Awards}

Each Laboratory employee at the $X-10$ site and on the payroll as of December 31,1980 , earned a $\$ 13.50$ safety award.

\subsection{Long Range Plans for Industrial Safety}

Industrial Satety has the responsibility for assisting management in the formulation and direction of the Laboratory's Safety Program and to help develop and maintain a high level of safety awareness among all Laboratory employees, througil, a program consistent with UCC-ND and UCC safety policies. 
In order to fulfill these objectives, the safety staff assists the management line organization and Laboratory personnel in all areas relating to personnel safety and accident prevention. A principal function is to aid Laboratory division representatives in the development of action plans to adequately serve their safety requirements. Includer in the action plans are the routine activities normally associated with a successful safety program, i.e., (1) conducting safety meetings and safety inspections; (2) investigating, analyzing, and reporting on all accidents and near misses; (3) formulation and issuance of policies, guides, procedures, and standards; (4) providing education and training services; (6) conducting periodic safety performance appraisals; (7) seeking to improve off-the-job safety performance; and (8) preparing records and reports.

Future action plans within the section include seeking ways to help reduce the number of of $f$-the-job injuries. Off-the-job injuries result in huge monetary loss to the Laboratory, as well as cause pain to the injured. Effort will continue to be made to obtain the best safety material possibıe (visual aids and written material), as well as discussion of subjects in safety meetings.

Presentation of education and training programs by members of the Safety staff has always been recognized as an important part of the safety effort at the Laboratory. Defensive driving, hazard potential recognition, supervisor development program, and orientation for new hires are some of the programs now underway. Future plans call for continuing these programs and adding others as changes in the Laboratory's major activities may dictate. Also, the safety staff will continue to attend approved outside training courses and seminars that will assure their keeping up to date on modern techniques in the field of safety.

During each of the past five years, the Laboratory has achieved the highest safety award honors that the Union Carbide Corporation and the National Safety Council can bestow. As of January 1, 1980, Union Carbide Corporation has revised the safety award program, making it much more difficult to achieve the top award. (At the present plant population figure, this would mean working approximately two years wi thout a disabling injury.) Achieving this top honor, however, rates as a future challenge for the Industrial Safety Section and all Laboratory personnel. 
Table 6.1.1 ORNL Injury Statistics (1971-1980)

\begin{tabular}{|c|c|c|c|c|c|c|c|}
\hline & \multicolumn{3}{|c|}{ Disabling Injuries (DI) } & \multirow{2}{*}{$\frac{\text { Workday }}{\text { LWCIR }}$} & \multirow{2}{*}{$\frac{\text { Cases (LWC) }}{\text { LWIR }}$} & \multicolumn{2}{|c|}{$\begin{array}{l}\text { Recordable Injuries } \\
\text { and Illizesses (RII) }\end{array}$} \\
\hline & Number & $\begin{array}{l}\text { Frequencr } \\
\text { Rate }^{a}\end{array}$ & $\begin{array}{l}\text { Severity } \\
\text { Rateb }\end{array}$ & & & Number & Incidence Rate \\
\hline $\begin{array}{l}1971 \\
1972 \\
1973 \\
1974 \\
1975 \\
1976 \\
1977 \\
1978 \\
1979 \\
1980\end{array}$ & $\begin{array}{l}4 \\
7 \\
2 \\
5 \\
2 \\
1 \\
1 \\
3 \\
3 \\
2\end{array}$ & $\begin{array}{l}0.61 \\
1.08 \\
0.33 \\
0.81 \\
0.27 \\
0.13 \\
0.12 \\
0.36 \\
0.36 \\
0.23\end{array}$ & $\begin{array}{r}298 \\
52 \\
24 \\
51 \\
24 \\
14 \\
9 \\
7 \\
8 \\
17\end{array}$ & $\begin{array}{l}- \\
- \\
- \\
- \\
- \\
- \\
- \\
0.07 \\
0.07 \\
0.05\end{array}$ & $\begin{array}{c}- \\
= \\
= \\
= \\
- \\
1.30 * \\
1.64 \\
3.45\end{array}$ & $\begin{array}{l}38 \\
49 \\
35 \\
30 \\
82 \\
51 \\
64 \\
59 \\
44 \\
41\end{array}$ & $\begin{array}{l}5.8 \\
7.6 \\
5.8 \\
6.9 \\
2.25 \\
1.33 \\
1.60 \\
1.40 \\
1.05 \\
0.96\end{array}$ \\
\hline
\end{tabular}

- Since 1975 the serious injury frequency rate has been based on OSHA system for recording injuries illnesses.

*Starting with 1978 annual report, the lost workday cases incidence rate (LWCIR) and the lost workday incidence rate (LWIR) is being based on the OSHA system ANSI $(216,4-1977)$ for measuring lust workday experience:

LWCIR = $\frac{\text { No. of Cases Involving Days Away from Work }}{\text { Exposure of Employee-hours }}$

LWIR - Total Lost Workdays or Days Charged $\times 200,000$

Exposure or Employoo-hours

a Frequency Rate for DIs - Number of Casos with Days lost or Charged X 1,000,000 Employee-hours

bSeverity Rate $=$ Total Number of Days Lost or Charge, $x 1,000,000$

Enployeo-hours

CIncidence Rate for RIIs = Number of RIIs X 200,000 (1975 and later)

Euployeo-hours 
Table 6.1.2 Lost Workday History - ORNL (1976-1980) ${ }^{a}$

\begin{tabular}{|c|c|c|c|c|c|}
\hline & 1976 & 1977 & 1978 & 1979 & 1980 \\
\hline Nuber of Injuries & 1 & 1 & 1 & 3 & 2 \\
\hline Labor Heurs (Millions) & 7.6 & 8.0 & 8.4 & 8.4 & 8,5 \\
\hline Incidence Rate & 0.03 & 0.02 & 0.07 & 0.07 & 0.05 \\
\hline Days Lost or Charged & 106 & 70 & 55 & 59 & 147 \\
\hline Severity Rate & 2.8 & 1.8 & 1.30 & 1.64 & 3.45 \\
\hline
\end{tabular}

${ }^{a}$ Cases involving days away from work. 
Table 6.1.3 ORML Disabling Irjury Frequensy Rates or Lost Workday Cases Inridence Rate (see Table 0.1.1) Since Inception of Carbirie Contract Comared with Rat.s for RSC, DOF and UCC

\begin{tabular}{|c|c|c|c|c|}
\hline Year & ORNL & הSC & DOE & $\mathrm{JCC}$ \\
\hline $\begin{array}{l}1949 \\
1950 \\
1951 \\
1952 \\
1953 \\
1954 \\
1955 \\
1956 \\
1957 \\
1958 \\
1959 \\
1960 \\
1961 \\
1962 \\
1963 \\
1964 \\
1965 \\
1966 \\
1967 \\
1968 \\
1969 \\
1970 \\
1971 \\
1972 \\
1973 \\
1974 \\
1975 \\
1976 \\
1977 \\
1978 \\
1979 \\
1980\end{array}$ & $\begin{array}{l}1.54 \\
1.56 \\
2.09 \\
1.39 \\
1.43 \\
0.79 \\
0.59 \\
0.55 \\
1.05 \\
1.00 \\
1.44 \\
0.94 \\
1.55 \\
1.45 \\
1.55 \\
1.07 \\
2.34 \\
0.64 \\
0.50 \\
0.13 \\
0.27 \\
0.76 \\
0.61 \\
1.08 \\
0.33 \\
0.81 \\
0.27 \\
0.13 \\
0.12 \\
0.07 \\
0.07 \\
0.05\end{array}$ & $\begin{array}{r}10.14 \\
9.30 \\
9.06 \\
8.40 \\
7.44 \\
7.22 \\
6.96 \\
6.38 \\
6.27 \\
6.17 \\
6.47 \\
6.04 \\
5.99 \\
6.19 \\
6.12 \\
6.45 \\
6.53 \\
6.91 \\
7.22 \\
7.35 \\
8.08 \\
8.87 \\
9.37 \\
10.17 \\
10.55 \\
10.20 \\
13.10 \\
10.87 \\
8.07 \\
2.56 \\
2.67 \\
-2 .-\end{array}$ & $\begin{array}{l}5.35 \\
4.70 \\
3.75 \\
2.70 \\
3.20 \\
2.75 \\
2.10 \\
2.70 \\
1.95 \\
2.20 \\
2.15 \\
1.60 \\
2.05 \\
2.00 \\
1.60 \\
2.05 \\
1.80 \\
1.75 \\
1.55 \\
1.27 \\
1.52 \\
1.28 \\
1.44 \\
1.40 \\
1.45 \\
1.60 \\
2.50 \\
1.04 \\
1.10 \\
1.20 \\
1.10 \\
1.10\end{array}$ & $\begin{array}{l}4.91 \\
4.57 \\
4.61 \\
4.37 \\
3.61 \\
3.02 \\
2.60 \\
2.27 \\
2.41 \\
2.21 \\
2.16 \\
1.92 \\
2.03 \\
2.28 \\
2.10 \\
2.20 \\
2.40 \\
2.57 \\
2.06 \\
2.24 \\
2.49 \\
2.27 \\
2.05 \\
1.73 \\
1.50 \\
0.99 \\
0.61 \\
0.86 \\
0.67 \\
0.75 \\
0.03 \\
0.04\end{array}$ \\
\hline
\end{tabular}

astarting with 1978 for ORNL ald 1979 for UCC, the OSH system (ANSI 216.4-1977) is being used for measuring lost workday experience. This means that rates are now calculated on the basis of 200,000 employeeh.jurs rather than $1,000,0$ no employee-hours. 
Table 6.1.4 Injury Statistics by Division - 1980

\begin{tabular}{|c|c|c|c|c|c|c|c|}
\hline \multirow{2}{*}{ División } & \multirow{2}{*}{$\begin{array}{l}\text { Medical } \\
\text { Reports } \\
\text { Received }\end{array}$} & \multicolumn{2}{|c|}{$\begin{array}{l}\text { Recordable Injuries } \\
\text { and Illnesses }\end{array}$} & \multicolumn{3}{|c|}{$\begin{array}{l}\text { Disabling Injurles } \\
\text { Lost Workday Cases (LWC) }\end{array}$} & \multirow{2}{*}{$\begin{array}{c}\text { Exposure } \\
\text { Hours } \\
\text { (In Millions) }\end{array}$} \\
\hline & & Number & Incidence & Number & $\begin{array}{l}\text { Frequency } \\
\text { (LWCIR) }\end{array}$ & $\begin{array}{l}\text { Severity } \\
\text { (LWIR) }\end{array}$ & \\
\hline $\begin{array}{l}\text { Analytical Chemistry } \\
\text { Chemistr? } \\
\text { Central Management } \\
\text { Conputer Sciences } \\
\text { Chemical Technology } \\
\text { Engineering } \\
\text { Energy } \\
\text { Engintering Physics } \\
\text { Enployee Relations } \\
\text { Environmental Sciences } \\
\text { Finance \& Materials } \\
\text { Health } \\
\text { H \& S Research } \\
\text { Information } \\
\text { Instr. and Controls } \\
\text { Ind. Safety \& AHP } \\
\text { Laboratory Protection } \\
\text { Netals \& Ceranics } \\
\text { Operations } \\
\text { Physics } \\
\text { Plant \& Equipment } \\
\text { QA \& Inspection } \\
\text { Solid State }\end{array}$ & $\begin{array}{r}14 \\
6 \\
0 \\
3 \\
18 \\
6 \\
6 \\
3 \\
7 \\
3 \\
17 \\
3 \\
4 \\
9 \\
27 \\
6 \\
20 \\
18 \\
34 \\
2 \\
180 \\
2 \\
3\end{array}$ & $\begin{array}{r}2 \\
2 \\
0 \\
0 \\
1 \\
1 \\
0 \\
0 \\
0 \\
1 \\
3 \\
0 \\
0 \\
0 \\
1 \\
0 \\
2 \\
3 \\
3 \\
0 \\
22 \\
0 \\
0\end{array}$ & $\begin{array}{l}1.68 \\
2.06 \\
0 \\
0 \\
0.31 \\
0.45 \\
0 \\
0 \\
0 \\
0.61 \\
1.74 \\
0 \\
0 \\
0 \\
0.45 \\
0 \\
2.23 \\
1.10 \\
1.14 \\
0 \\
2.32 \\
0 \\
0\end{array}$ & 1 & $\checkmark .45$ & 30.3 & $\begin{array}{l}.238 \\
.195 \\
.131 \\
.467 \\
.646 \\
.442 \\
.270 \\
.142 \\
.183 \\
.326 \\
.345 \\
.069 \\
.248 \\
.539 \\
.448 \\
.186 \\
.179 \\
.543 \\
.527 \\
.209 \\
. .899 \\
.067 \\
.212\end{array}$ \\
\hline PLANT TOTAL & 393 & 41 & 0.96 & 2 & 0.05 & 3.45 & 8.511 \\
\hline
\end{tabular}


Table 6.1.5 Disabling Injury Accident (Lost Morkday Case)

Free Periods - ORNI. (1972-1980)

Accident-Free Period

Employee-Hours Accunulated

December 12, 1972 - April 25, 1973

$2,327,051$

April 27, 1973 - July 29, 1973

$1,428,975$

July 31, 1973 - January 15, 1974

$2,760,549$

January 17, 1974 - May 6, 1974

$1,869,338$

May 8, 1974 - June 15, 1974

661,399

June 17, 1974 - August 11, 1974

926,437

August 13, 1974 - Decerber 5, 1974

$2,010,547$

December 7, 1974 - April 6, 1975

$2,570,944$

April 8, 1975 - November 10, 1975

$4,543,462$

November 12, 1975 - September 15, $197 €$

$6,375,994$

September 17, 1976 - April 24, 1977

$4,588,847$

April 26, 1977 - January 14, 1978

$5,830,521$

January 16, 1978 - September 26, 1978

$6,041,210$

September 27, 1978 - March 23, 1979

$3,826,579$

March 26, 1979 - September 14, 1979

$4,007,810$

September 17, 1979 - October 24, 1979

$1,096,371$

May 10, 1980 - December 31, 1980

$5,405,407$

Best Accident-Free Period

July 4, 1968 - August 20, 1969

$8,529,750$ 
Tablc 6.1.6 Number and Percent of Accidents by Type - 1980

\begin{tabular}{lrc}
\hline \multicolumn{1}{c}{ Type of Accident } & Muber & Percent \\
\hline Struck Against & 142 & 36.2 \\
Struck By & 92 & 23.7 \\
Slip, Twist & 51 & 12.9 \\
Caught In, On, Between & 33 & 8.4 \\
Contact with Temp. Extreres & 13 & 3.3 \\
Fall, Same Level & 39 & 9.9 \\
Inhalatior., Absp., Ingestion & 7 & 1.8 \\
Fall, Different Level & 5 & 1.3 \\
Other & 10 & 2.5 \\
\multicolumn{1}{c}{ Toral } & 393 & 100.0 \\
\hline
\end{tabular}


ORNL-DWG 77-5241

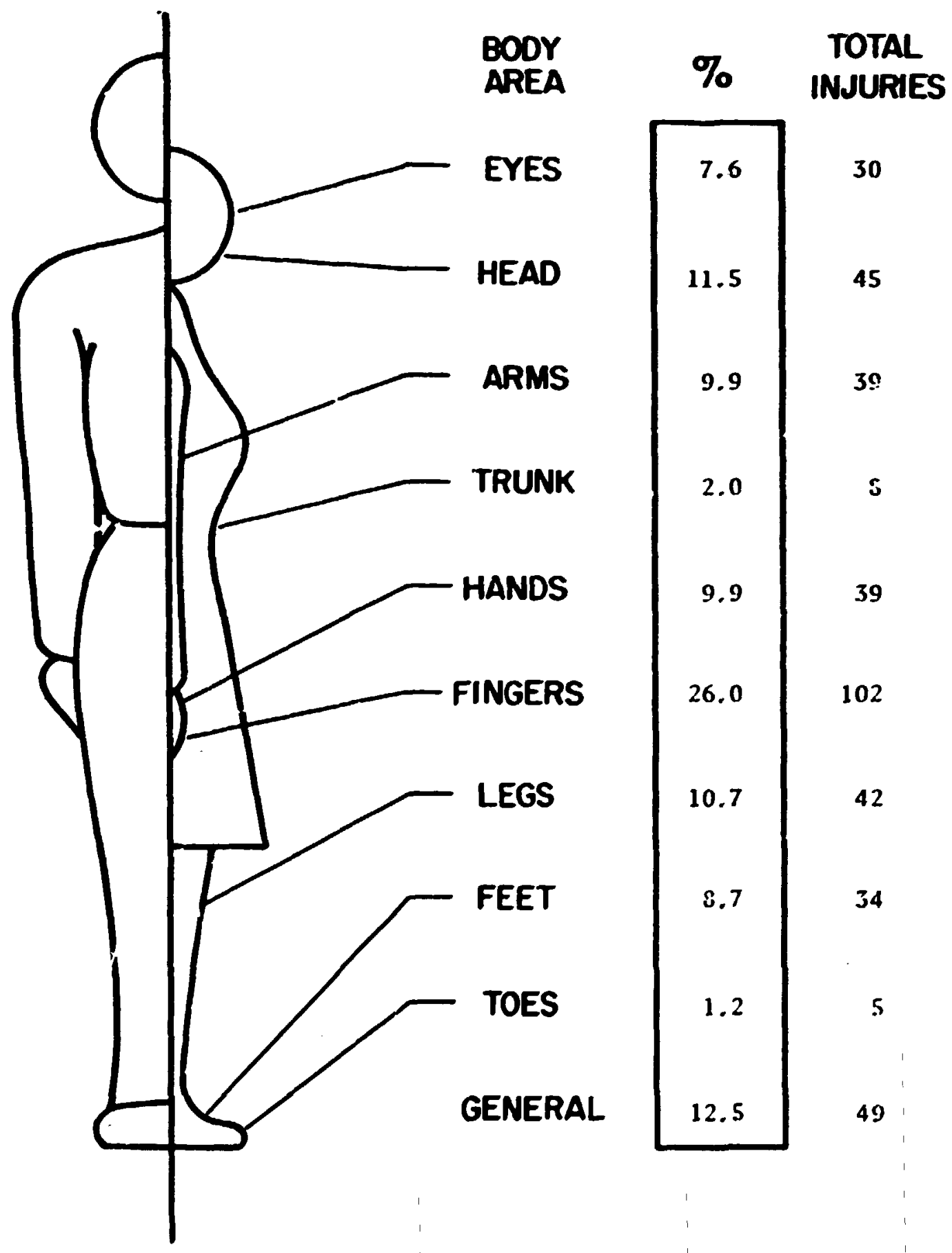

Fig. 6.1.1 Part of Body Injured 
Table 6.1.7 Nuber and Percent of Accidents

by Nature of Injury - 1980

\begin{tabular}{lrr}
\hline Nature of Injury & Number & Percent \\
\hline Laceration, Puncture & 144 & 36.6 \\
Contusion, Abrasion & 96 & 24.4 \\
Strain & 53 & 13.5 \\
Burn, Temperature & 26 & 6.6 \\
Sprain & 24 & 6.1 \\
Conjunctivitis & 26 & 6.6 \\
Burn, Chemical & 12 & 3.1 \\
O.ner & 12 & 3.1 \\
\multicolumn{1}{c}{ Toral } & 393 & 100.0 \\
\hline
\end{tabular}


Table 6.1.8 Tabulation of Injuries by UCC-ND Facility - 1980

\begin{tabular}{|c|c|c|c|c|c|c|c|}
\hline \multirow[b]{2}{*}{ Plant } & \multirow{2}{*}{$\begin{array}{c}\text { Laior } \\
\text { Hours } \\
\text { (Millions) }\end{array}$} & \multicolumn{4}{|c|}{ Lost Workday Cases } & \multicolumn{2}{|c|}{$\begin{array}{c}\text { Recordable Injuries } \\
\text { and Ilinesses }\end{array}$} \\
\hline & & $\begin{array}{l}\text { Number of } \\
\text { Injuries }\end{array}$ & $\begin{array}{l}\text { Incidence } \\
\text { Rate } \\
\text { (LWC IR) }\end{array}$ & $\begin{array}{l}\text { Days Lost } \\
\text { or Uharged }\end{array}$ & $\begin{array}{c}\text { Severity } \\
\text { Rate } \\
\text { (LWIR) }\end{array}$ & $\begin{array}{l}\text { Number of } \\
\text { Injuries } b\end{array}$ & $\begin{array}{c}\text { Incidence } \\
\text { Rate }\end{array}$ \\
\hline ORNL & 8.5 & 2 & 0.05 & 147 & 3.45 & 41 & 0.96 \\
\hline ORGDP & 11.3 & 2 & 0.04 & 348 & 6.18 & 55 & 0.96 \\
\hline$Y-12$ & 12.8 & 1 & 0.02 & 52 & 0.81 & 80 & 1.25 \\
\hline Paducah & 3.7 & 2 & 0.11 & 180 & 9.68 & 25 & 1.34 \\
\hline
\end{tabular}

a Starting with 1978 annual report the OSHA system (ANSI 216.4-1977) is being used for measuring lost workday experience.

b Includes the number of Lost Workday Cases. 
Table 6.1.9 Notor Vehicle Accidents (1976-1980)

\begin{tabular}{lrrr}
\hline Year & Number & $\begin{array}{c}\text { Frequency } \\
\text { Rate }^{\mathrm{a}}\end{array}$ & Danage \\
\hline & & & \\
1976 & 14 & 6.42 & $\$ 5,136$ \\
1977 & 12 & 5.05 & $\$ 8,488$ \\
1978 & 29 & 13.49 & $\$ 9,009$ \\
1979 & 17 & 8.39 & $\$ 4,612$ \\
1980 & 6 & 3.31 & $\$ 3,570$ \\
\hline
\end{tabular}

$a_{\text {Frequency }}=\frac{\text { No. of Motor Vehicle Accidents } \times 1,000,000}{\text { No. of Miles Driven }}$

Table 6.1.10 Number of Firss (1976-1980)

\begin{tabular}{|c|c|c|}
\hline Year & Number & Damage \\
\hline $\begin{array}{l}1976 \\
1977 \\
1978 \\
1979\end{array}$ & $\begin{array}{l}0 \\
0 \\
2 \\
0\end{array}$ & $\begin{array}{lr}\$ & 0 \\
\$ 16,095 & 0 \\
\$ & 0\end{array}$ \\
\hline 1980 & 0 & $\$$ \\
\hline
\end{tabular}


Table 6.1.11 Mhber and Type of Off-The-Job Disabling Injuries (1976-1980)

\begin{tabular}{lrrrrr}
\hline & 1970 & 1977 & 1978 & 1979 & 1980 \\
\hline Transportation & 20 & 11 & 22 & 16 & 18 \\
Hone & 17 & 11 & 28 & 34 & 24 \\
Public & 9 & 12 & 21 & 22 & 21 \\
Total & 46 & 34 & 71 & 72 & 63 \\
Days Lost & 1,251 & 765 & 1,055 & 1,499 & 992 \\
Frequency Rate & 2.91 & 1.98 & 3.95 & 4.00 & 3.44 \\
Fatalities & 5 & 0 & 0 & 1 & 2 \\
\hline
\end{tabular}

${ }^{a}$ Frequency $=\frac{\text { No. of Off-the-Job Disabling Injuries } \times 1,000,000}{\text { Exposure Hours }}$

* Exposure Hours = 312 Hours/Employee Month. 


\subsection{OFFICE OF MDERATIONAL SAFETY}

The Office of Operational Safety serves as the focal point for the operational safety activities (including reactor and riticality safety) of ORNL and provides liaison between ORNL, the UCC-ND Health, Safety, and Enviromental Affairs Office, and the Department of Energy (DOE-ORO) on operational safety matters. A prinary responsibility of the office is coordinating and monitoring the activities of the Divisior Safety Officers and Radiation Control Officers and the laboratory Director's Review Comnttees, and ensuring follow-up of Comittee recomendatior.s. The staff of the office also particifates in a wide variety of operational safety matters, including development of safety policies, procedures, practices, and guidelines for various I iboratory operations. Through review and approval functions, the office provides management assurance that Laboratory safety requirements are included in the design, modification, and construction of facilities and that all facilities are operated safely in accordance with ORNL and DOE requirerents. The director of the office serves as the Laburatory's safety docunentation and review coordinator in accordance with Standaid Practice lrocedure D-5-29. In fulfilling this responsibility, the director and office staff provide coordination, direction, and app roval of safety documentation to assure compliance with Loboratory and DOE requiresents. The office additionally provides coordination of safety activities in the decontanination and decomissioning program to assure that all environmental, safety and health physics concerns are included.

\subsection{Laboratory Director's Review Comittees}

The Office of Operational Safet; continued to coordinate the activities of the ORNL's Direstor's Review Comittees during 1980. The Laboratory has eight standing committees whose work is coordinated by the COS. These comittees are responsible for review and recomendations for operations wherein significant or unique hazarcis exist.

In the coordinating role, the oos is responsible for scheduling comittee reviews, participating in reviews as ex-officio members of the comittee, finalizing reports documenting the reviews, and seeing that recomendations formulated as a result of the reviews are eithcr implemented or resolved in a manner sicisfactory to managenent. The 1980 activities of the various review comittees are show in Table 7.1.1.

The OOS continued tie practice startcd in 1979 of having each comonittee hold an annual meeting with Clyde $C$. Hopkins to discuss their work for the year and to raise any issues or concerns not covered in formal comnittee reports. 


\subsection{Inplementation of DOE Manual Chapter 0531 and DOE Order 5481.1 Requirements}

Enactnent of DOE Mamual Chapter 0531, "Safety of Nonreactor Nuclcar Facilities," and subsequently DCE Order 5481.1, "Safety Analysis and Review Systea," sigaificantly impacted on the focumentacion 1 squirenents of facilities identified as "nonreactor" nuclear facilities. This manual chapter and order specify requirements of S's (Safety Assessments), PSARs (Preliminary Safeiy Analysis Reports), FSAPs (Final Safety Analysis Reports), and OSRs (Operating Safety Requireaents) for all such facilities. (PSARs are required for new or major modified facilities only.) It is required that these documents be developed in sequence with various stages of completion of a facility or project so that upon completion of construction or comencenert of a project, the documentation requirements are also completed. It also requires that documentation supporting the safe operation of existing facilities be produced or revised to conform to specific requirements and format.

DOE Order 5481.1 expands safety documentation requizements to cperations having hazards of a type and magnitude not routinely encountered anc/or accepted by the public.

While there were a limited number of new facilities or projects requiring such docunentation, there are muerous existing nonreactor nuclear facilities which have not completed developwent of tine required documents. Initially (during :978) there were 33 existing facilities which were identified as being in this category. During 1979 a schedule of implementation of the $M C 531$ document requirements for these existing facilities (modified to include 28 facilities) was developed and was shown in Table 7.2.1 in ORNI 5663. An updated schedule is shown in Table 7.2.1. The schedule will be revised as necessary to include any additional facilities which require safety documentation in accordance with Order 5481.1.

During 1980 safety analysis documentation continued on the 7920 TRU Facility; 3019 Pilot Plant and 3100 Jault; a site generic document; Solid Waste Storage Facility; the Tritium Target Facility, 7205, and the 5505 TRL Facility with :cheduied completion dates for Safety Analysis Reports and Operating Safety Requirements revised to accomodate completion in mid 1981. The Intermediate Level Wa'te Operating Safety Requirements document was completed and final drafts of FSARs for the Building 3027 Vault and Holified Heavy Ion Research Facility were submitted to DOE for approval.

\subsection{RCO-USO Activities}

Operating and research divisiuns at the Laboratory have appointed Radiation Control and Division Safety Officers who are responsible for coordinating radiation safety and other safety matters, respectively with the divisions they represcnt. Show in Table 7.3.1 is a list of $\mathrm{RCOS}$ and DSOs and the divisions they represent. 
The OOS conducts quarterly meetings for the purpose of disseminating information of interest and importance to the safety officers. During 1980 the meetings were conducted on Jaruary 22, April 15, July 23 , and Dctober 14. The meetings are documented in ORNL/LF-80/39, ORNL/CF-80/86, ORNL/CF-80/261, and ORNL/CF-80/344. The OOS also reviews and comments on safety analysis reports, project safety summaries, safety inspections, and reports of accidents submitted by the safety officers. It also reviews operations for recommendation and approval; the requirements of which are not specificilly covered in manuals.

\subsection{Staff Consultation, Review, and Other Activities}

In order to assire continuance of and promote safety in operation of laboratory facilities, the cos engages in activities in addition to those previously described.

The staff engaged in numerous consultations with members of operating facility staffs and performed reviews and audits of both routine and requested operations and facilities. Numerous requests were received for r.pproval of proposed experiments or nperations, inciuding disposal of radicactive wastes, handiing and processing speciai radioactive materials, and transportation of nuclear materials.

Cther staff activities included participating in all accident or "near miss" investigations and assisting or observing emergency drill performance. The staff also participates $j_{1}$ and develops procelures for the Health Physics and Safety Manuals. Charters for the Director's Electrical Safety and Transportation Committees were completed.

Assistance was given to several groups in the design and p:ncurement of glove boxes. Additionally, the staff assisted in the review of decontamination and decomissioning criteria, determination of appropriate site boundaries for safety analysis documertation, proposed Laboratory facility siting, and seismic and wind criteria for the ORNL area.

Considerable staff effort "as required in particpatisig in and answering questions raisec as a resul 4 of review of the HF'R by DOE's Nuclear Facility Personnel Qualification and Training Committee (Crawford Comuittee).

As part of the responsioility for providing 1 iaison between ma:agement :- DOE on safety matters, many meetings were held with DOE safety, taff. These included participation in the following: 
DOE Occupational Safety and Health Progran Audit - April 8

DOE Industrial and Construction Safety Audit - July 21-25

DOE Nuclear and Criticality and Transportation Safety Audit September 15-22

Crawford Committee (NFPQT) - October 20-24

DOE Environuental Management Appraisal - October 21-23

DOE Annual Health Physics Appraisal - December 1-12

DOE Appraisal of ORNL Emergency Preparedness Frogram - July 29-31

DOE Reactor Safety Appraisal (not complete)

DOE Nulcear Facility Safety Appraisal (MC 0531) - March 3-7

DS responsibilites in audits also include ensuring follow-up of audit recommendations and providing implementation progress reports when required.

The office also participated in the UCC-ND Safety and Health Audit.

\subsection{Summary}

During 1980 there were no facility or nuclear rtactor accidents or incidents of an operational nature which resulted in injury to personnel or which were reportable to DOE.

The cos continued to review and ensure review of operations and facilities by appropriate Director's Committees to assure maragement of continued safe operation of all Laboratory facilities. Hork continued on implementation of MC 0531 and DOE Order 5481.1 by allocation of funds and revision of schedules and programs for completion of safety analysis reports for existing farilities. A greater effort in the development of criteria for decontami..dtion and decommissioning continued. 
Table 7.1.1 Sumuary of Meetings Held in 1980 by Laboratory Direcior's Review Comittees

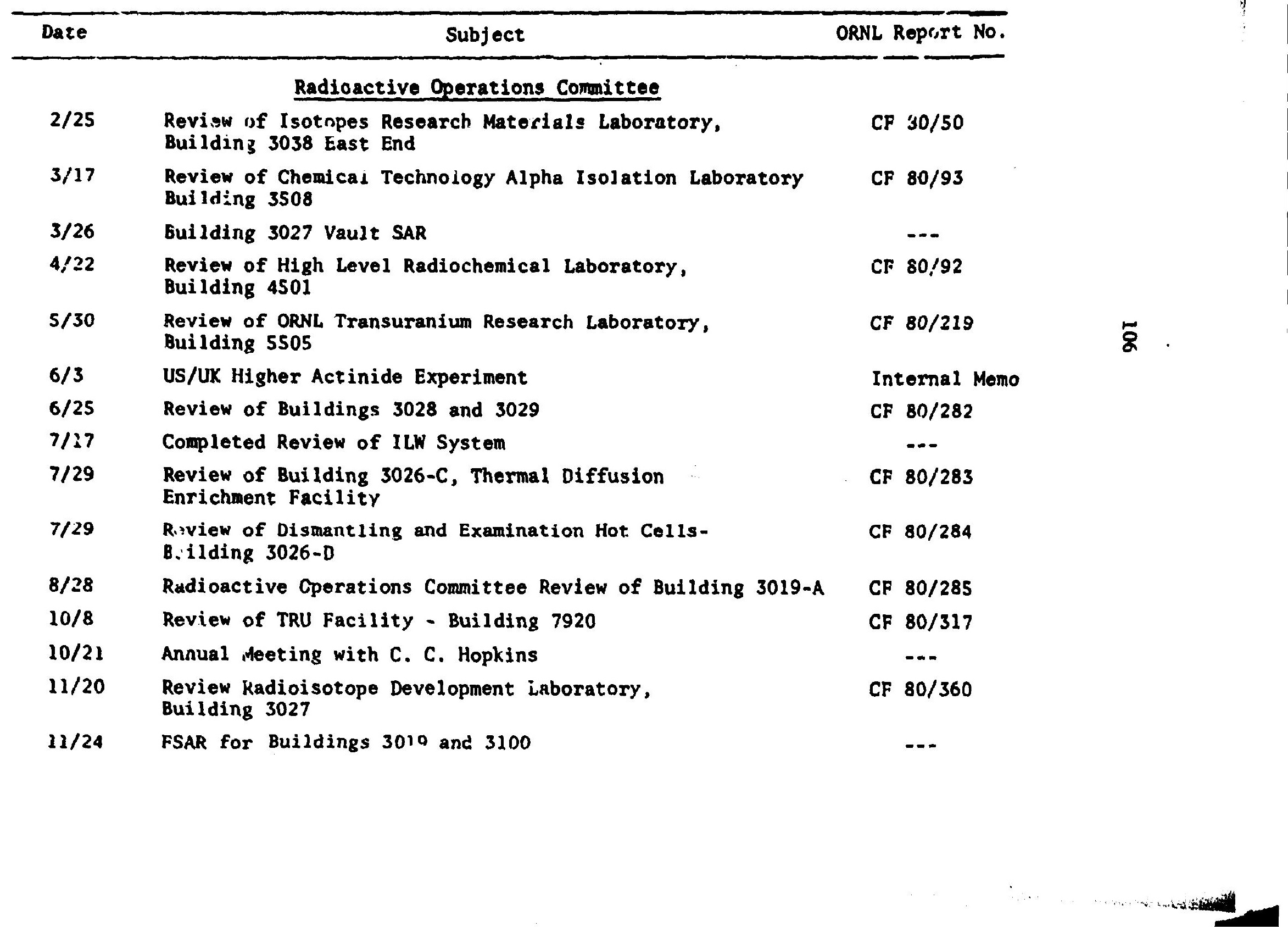


Table 7.1.1 Sunmary of Meetings Held in 1980 by Laboratory Director's Roviow Committees

\begin{tabular}{|c|c|c|}
\hline Date & Subject & ORNL Report No. \\
\hline \multicolumn{3}{|c|}{ Accelerarors and Radiation Sources Review Committoe } \\
\hline $\begin{array}{l}1 / 31 \\
2 / 7-8 \\
5 / 14\end{array}$ & Review SAR for Heavy Ion Facility & --- \\
\hline $3 / 4$ & $\begin{array}{l}\text { Review J. L. Shepherd \& Associates }{ }^{60} \text { Co Irradiation in } \\
\text { BG-71, Building } 1501\end{array}$ & CF $\cdot 80 / 75$ \\
\hline $6 / 12$ & Review of Source üroup C & CP $80-245$ \\
\hline $9 / 24$ & Review URELA in Building 6010 & CF $80 / 312$ \\
\hline $10 ! 16$ & Annual meeting with C. C. Hopkins & $-\cdots$ \\
\hline \multicolumn{3}{|c|}{ Beactor Ouerations Reviow Committes } \\
\hline $\begin{array}{l}1 / 24, \\
318 \\
5 / 22\end{array}$ & 1979 Annual Review of HFIR & CF $80 / 218$ \\
\hline $\begin{array}{l}1 / 24 \\
1 / 31\end{array}$ & 1979 Annual Review of TSF & $\cdots$ \\
\hline $2 / 26$ & Finalize 1979 Reports on TSF, ORR, HPRR, BSR & $\begin{array}{l}\text { HPRR CF } 80 / 20 \\
\text { CRR CF } 80 / 51 \\
\text { TSF CF } 80 / 52\end{array}$ \\
\hline $\begin{array}{l}3 / 20 \\
4 / 16\end{array}$ & 1.779 Annual Review of BSF & CF $80 / 52$ \\
\hline $\begin{array}{l}3 / 25 \\
4 / 2\end{array}$ & $\begin{array}{l}\text { Special meeting to discuss hypothotical cooling system } \\
\text { failure at ORR }\end{array}$ & -- \\
\hline $6 / 10$ & Quarterly Moeting & $\cdots$ \\
\hline $10 / 29$ & Quarterly Meeting & --- \\
\hline $10 / 29$ & Annual meeting with C. C. Hopkins & $\cdots$ \\
\hline
\end{tabular}


Table 7.1.1. Sumpary of Meetings Held in 1980 by Laboratory Director's Review Comnittees

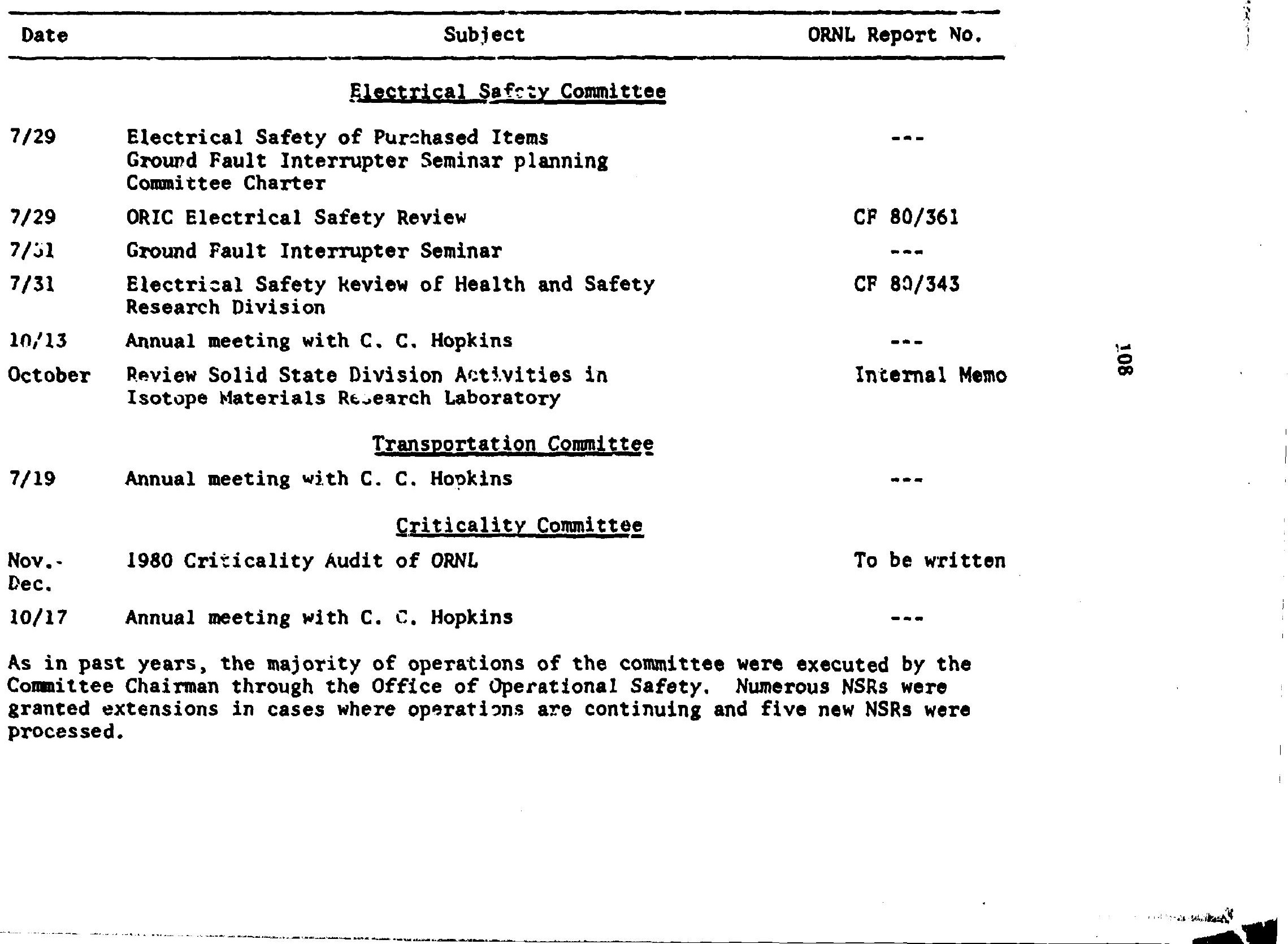


Table 7.1.1 Summary of Mectings Held in 1980 by Laboratory Director's Review Comnittees

Date

$1 / 8$

$3 / 19-24$

TRIGA-LEU isperiment in ORR

2/28 Periodic Review of HSST BSR Experiment

4,10 ORR Poolside Facility (PVS)

4/24 HFEO- $i-D 2$ Experiment in ORR

5/8 ORR Experiment MFE 4

$5 / 26$

7/11 Gamma Thermometer Experiment in ORR

7/15 HFED Experiment in ORR

9/18 MFE ${ }^{3}$ Experiment in ORR (Preliminary Review)

$7 / 10 \quad$ NFE $^{5}$ Experiment in ORR

$10 / 2$

$10 / 9$
Annual meeting with C. C. Hopkins
ORNL Report No.

Approved in Memo

from G. H. Jenks to

C. C. Hojkins

January 8, 1980

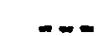

Momo Jenks to

Hopkins $4 / 1.5 / 80$

Memo Jenks tc Hopkins

May 15 \& 27, 1980

Memo Jenks to Hopkins $6 / 10 / 80$

Memo Jonks to Hopkins $7 / 31 / 80$

Memo Jenks to Hopkins $7 / 10 / 80$

Not Complete

Memo Jenks to Hopkins $10 / 14 / 80$

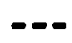


Table 7.1.1 Sumary of Meetings Heid in 1980 by Laboratory Director's Roview Committees

\begin{tabular}{|c|c|c|}
\hline Date & Subject & ORNL Report No. \\
\hline \multicolumn{3}{|c|}{ High Pressure Equipment Review Committee } \\
\hline $\begin{array}{l}3 / 21 \\
4 / 9\end{array}$ & Gold-Cell Hydrothermal Equipment F-255, Buiding 4500 S & Internal memo $5 / 16 / 80$ \\
\hline $4 / 9$ & High Pressure, High Temperature Systen BG-72, 4501 & Internal memo $5 / 16 / 80$ \\
\hline $5 / 22$ & Autoclave Installation, Bullding 3592 & $\cdots$ \\
\hline $\begin{array}{l}6 / 12 \\
7 / 25\end{array}$ & High Pressure Experiment on Alpha-Uranium, HFIR & Internal memo $7 / 28 / 80$ \\
\hline $8 / 1$ & Now Hydrofracture Project & Internal memo $8 / 5 / 80$ \\
\hline $9 / 10$ & High Pressure, High Temperature system BG-72, 4501 & Internal memo $9 / 10 / 80$ \\
\hline $10 / 12$ & High Pressure, High Temperature System BG-72, 4501 & $-\cdots$ \\
\hline $12 / 2$ & Annual meeting with C. C. Hopkins & $\cdots$ \\
\hline
\end{tabular}

The Comittee reported they conducted is other inspections of high pressure equipment at ORNL during 1980 
Table T.2.I Implementerien Schedule aut for coplience

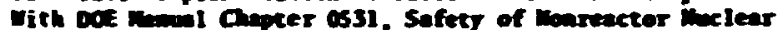

Fecilities (Safety Amalysis Deports, Suls: at Orerations sefety Requirment, (ans)

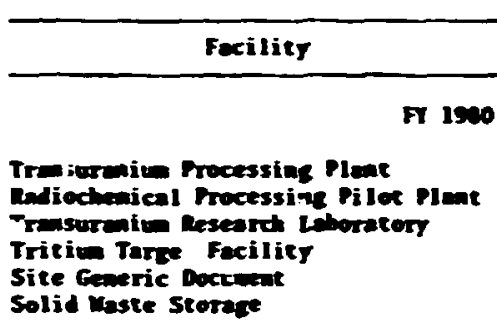

F Isat* ide. $\cos t(\sin / \cos )$

1500

$\begin{array}{lr}7020 & \$ 37,000 \\ 3019 & 37,000 \\ 5505 & 55,000 \\ 7025 & 23,000 \\ & 37,000 \\ & 55,000 \\ \text { Totel } & \$ 250,000\end{array}$

Trasareite Processine Pleat

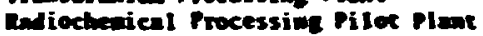
Transuraio mesearch Leboratery

Tritio Taret Facility

Site Generic Docusent

Solid inste storage

Elect romperic Seporation of

Hean Elemes (CS" Creloeron)

Hi th Level Analitical Lborator

Rediation Gas Handling - Operations

Alphe Isolation Laboritory

Noon 136 - rermic Fuels Alphe Techaologs

$\begin{array}{ll}7920 & 30,000 \\ 3019 & 20,000 \\ 5505 & 20,000 \\ 7025 & 30,300 \\ & 10,000 \\ & 20,000 \\ 9201-3 & 30,000 \\ 2026 & 60,600 \\ 30331 & 30,300 \\ 3502 & 60,000 \\ 4501 & 60,000 \\ \text { Totel } & 552,000\end{array}$

FI 1992

Alphe Handling Fecility

Indioi sotope Developent Lab

Alpha Isolat ion Labs

Geseous Waste

Electromaget ic Separation of Heery

Element:

3035

3047

tent

3039

9204-3

Total

FY 1983

High hadiation Level Exanination Lab Redioisotope Pachoging

Auliolsotcres Lab

Thoriu-Urenitu Recyele facility

3525

303:

3039

7954

Totel

$\$ 4.150$ 6.150

4,150

0,150

0,150

320,750

FY 1984

Indioisotope Production Develogent Lo Serent ine Cells

suree Developenent Lab

Low Level AInh Fachlizy

Isoteps mesearch interbels in

Toral

574,030

74,830

74,030

74,830

74,030

8374.200

Fr 1905

- Sir Enrichment

Fission Production Develogeme Leb

Hoe colls

Rolling MIII

Machine shop

\begin{tabular}{|c|c|}
\hline $\begin{array}{l}3026 \\
3517 \\
3025 \\
3012 \\
5044\end{array}$ & $\begin{array}{r}60,810 \\
60,810 \\
60,810 \\
00,810 \\
0,010 \\
\end{array}$ \\
\hline Total & sed, con \\
\hline
\end{tabular}

- Includes doccentacion bean in $\mathrm{N} 1940$ 
Table 7.3.1 Radiation Control officers and Division Safety Officers

\begin{tabular}{|c|c|c|}
\hline Division & DSO & RCO \\
\hline Analytical Chemistry & G. R. Wilson & G. R. Wilson \\
\hline Biology & D. G. Doherty & D. G. Doherty \\
\hline Chemical Technology & J. B. Ruch & J. B. Ruch \\
\hline Chemistry & C. E. Haynes & C. E. Haynes \\
\hline Computer Sciences & N. A. Betz & N. A. Betz \\
\hline Central Management & G. C. Cain & G. C. Cain \\
\hline Employee Relations & J. A. Holloway, Jr. & \\
\hline Energy & R. C. DeVault & R. C. DeVault \\
\hline Engineering & H. D. MacNary & H. D. MacNary \\
\hline Engineering Technology & C. A. Mills & A. W. Longest \\
\hline Engineering Physics & G. T. Chapman & G. T. Chapman \\
\hline Environmental iciences & M. H. Shanks & M. H. Shanks \\
\hline Finance \& Materials & G. E. Testerman & \\
\hline Fusion Energy & R. S. Edwards & R. S. Edwards \\
\hline Health Division & J. A. Ealy & J. A. Ealy \\
\hline Health \& Safety Research & J. P. Judish & J. D. Judish \\
\hline $\begin{array}{l}\text { Industrial Safety } \\
\text { Appl. Health Physics }\end{array}$ & D. C. Gary & D. M. Davis \\
\hline Information & E. J. Howard, Sr. & \\
\hline $\begin{array}{l}\text { Inst rumentation \& } \\
\text { Controls }\end{array}$ & R. A. Crowel 1 & M. M. Cr.lles \\
\hline Laboratory Protection & R. L. Atchley & H. C. Austin \\
\hline Metals \& Ceramics & W. H. Miller, Jr. & W. H. Miller, Jr. \\
\hline $\begin{array}{l}\text { MIT School of Engr. } \\
\text { Practice }\end{array}$ & K. j. Fallon & K. J. Fallon \\
\hline Operations & J. R. Gissel & J. R. Gissel \\
\hline Physics & R. L. Auble & R. L. Auble \\
\hline Plant \& Equipment & R. H. Winget & R. H. Winget \\
\hline $\begin{array}{l}\text { Quality Assurance } G \\
\text { Inspection }\end{array}$ & J. L. Holbrook & J. L. Holbrook \\
\hline Solid State & J. A. Setaro & J. A. Setaro \\
\hline
\end{tabular}




\subsection{PUBLICATIONS}

F. F. Haywood, P. T. Perdue, D. J. Christian, R. W. Leggett, H. W. Dickson, and T. E. Myrick, Radon and Kadon Daughter Measurements at on Near the Former Middlasex Sampling Piant, Middlesex, Nav Jersey, ORNL5489 (Febriâry 1980).

H. W. Dickson, Fourth Personnel Dcsimetry Intercompaxison Study, ORNL/TM7137 (February 1980).

F. F. Hayrood, D. J. Jacobs, H. M. Hubbard, Jr., B. S. E11is and W. H. Shinpaugh, Radiologica? Survey of the Inactive Uranium-Mill Tailings at Naturita, Colorado, ORNL-5454 (March 1980).

F. F. Haywood, D. J. Christian, B. S. Ellis, H. M. Hubbard, Jr., D. Lorenzo, W. H. Shinpaugh, Raaiolgoical Survey of the Inactive UraniwnMill Tailings at Green River, Utah, ORNL-5459, March 1980.

J. A. Auxier, "Health Effects of Low Level Radiation," Proceedings of i980 UCC-ND GAT Waste Management Seminar, CONF-800416, Apri 1980.

F. F. Haywood, W. A. Goldsmith, D. G. Jacobs, P. T. Perdur, B. S. Ellis, H. M. Hubbard, Jr. and W. H. Shinpaugh, Assessment of the Radiological impact of the Inactive Uranium-Mill Tailings ot Grand Junction, Colorado, ORNL-5457 (April 1980).

J. A. Auxier and W. F. Ohnesorge, Garma Exposure Rates Due to Neutron Activation of Soil: Site of Hood Detonation, Operation Plumbbct, ORNL/TM7406, (June 1980).

J. S. Eldridge, T. G. Scott, H. A. Parker, A. M. Stueber and T. W. Oakes, "Radionuclide Transport: Characterization of Species and Sources at a Solid Waste Disposal Site," Anolyticul Chemi try Division Anrual Progress Report for Period Ending December 31, 1979, ORNL-5619 (June 17, 1980).

J. S. Eldridge, T. G. Scott, T. W. Oakes and K. E. Shank, "Investigation of ${ }^{137} \mathrm{Cs},{ }^{60} \mathrm{Co}$, and ${ }^{30} \mathrm{Sr}$ Concentrations in water and Sediment as a Function of Flow in White Oak Creek," Analytical Chemistry Division. Anmual Progress Report for Period Ending December 31, 1.979, ORNL-5619 (June 17, 1980).

J. S. Eldridge, T. W. Oakes and K. E. Shank, "Specific Radionuclide Analyses Applied to Air-Monitoring Samples," Analytical Chemistry Division Annual Progress Report for Period Ending Desember 31, 1979, ORNL-5619 (June 17, 1980).

J. S. Eldridge, W. C. Massey, J. M. Mahathy and T. W. Oakes, "Gamma-Ray Spectrometry for Environmenta; Monitoring and Surveillance: Animd 1 Studies," Analytical Chemiatmy D'vision Annual Progress Report for Period Ending December 31, 1978, ORNL-S619 (June 17, 1980). 
S. A. Reynolds and J. S. Eldridge, "Cerenkov Counting cf Low-Level Beta Radioactivity," in Analyticai Chemistry Division 4nrua? Pragress Report for Period Ending Lecember 31, 1979, ORNL-S619 (June 17, 1980).

S. A. Reynolds and J. S. Eldridge, "Quality Assurance for the Special Projects Group," in Anclytical Chemistry Division Anoual Progmess Refort for Period Ending Denember 31, 1979, ORNL-5619 (June 17, 1980).

J. S. Eldridge, "Low-Level Gama Spcctronetry," in Analytical Chemistry Division Annual Progress Report for Period Ending December 31, 1979, ORNL-5619 (June 17, 1980).

J. S. Eldridge, "Radioactivity in Trench Water and Suspended Solits from the Waste Disposal Site at Maxey Flats, Kentucky," in Analytical Chemistry Division Annual Progress Report for Period Ending December 31, 1979, ORNL-5619 (June 17, 1980).

F. F. Haywood, D. J. Jacobs, B. S. Ellis, H. M. Hubbard, Jr., and W. H. Shinpaugh, Fadiological Survey of the Inactive Uronium-Mill Tailings at Rifle, Colorado, ORNL-5455 (June 1980).

F. F. Haywood, D. J. Christian, B. S. Ellis, H. M. Hubbard, Jr., D. Lorenzo and $W$. H. Shinpaugh, Radiological survey of the Inactive Uranium-Mill Tailings at Ambrosia Lake, New Mexico, ORNL-5458 (June 1980).

C. F. Holoway, P. M. Lantz, and H. W. Dickson, Evaluation of Docket Files for Terminated Speciul Muclear Material Licenses, MUREG/CR-1260, ORNL/NUREG/TM-352 (June J980).

T. W. Oakes, K. E. Shank and J. S. Eldridge, "Quality Assurance Applied tc Envirommental Radiological Surveillance," Mucl. Safety 21(2): 217 (1980).

J. A. Auxier and D. M. Davis, Industrial Safety and Applied Health

Physics Division Arnual Report for 2979, ORNL-5663, (September 1980).

W. F. Ohnesorge, H. M. Butler, L. B. Fulmer, and S. W. Mosko, "Heavy Ion Target Area Fast Neutron Dose Equivalent Rates," Health Phys., 39, pp. 633-636 (Octboer 1980).

C. D. Berger, R. E. Goans, R. T. Greene, The Whole Body Counting Eacility at Vak Ridge National Laboratory - Systems ana Procedure Review, ORNL TM-7477, (C ctob 2 r 1980).

F. F. Haywood, J. E. Burden, H. W. Dickson, D. R. Stone, W. D. Cottrel1, R. W. Doane, W. H. Shinpaugh, and W. A. Goldsmith, Radiological Swovey of the Former Bridgeport Brass Company Special Metals Extmuion Plant, Adrian, Michigan, ORNL-5713 (November 1980). 
R. W. Leggett, W. A. Goldsmith, W. D. Cottrell, H. T. Ryan, F. F. Haywood, P. T. Perdue, H. M. Dickson, J. L. Danek, J. E. Burden, M. G. Mason, D. L. Anderson, R. W. Doane, B. S. El lis, R. E. Hanilton, H. H. Shinpaugh, and D J. Crawford, Radiological Survys of the Mallinckrodt Chemical Works, St. Louis, Hissouri, ORNL-5715, (Noveabez 1980).

T. W. Oakes and B. A. Kelly, "Envi ronmental Regulations - Past, Present, and Future," in Proceedings of the 1980 UCC-ID and GAT Woste Management Seminar, CONF-800416 (Decenber 1980).

D. D. Stroud, J. R. Jones, M. E. Mitchell, T. M. Cakes, M. Sanders and M. B. Tate, "Maste Oil Disposal at the DOE-Oak Ridge Plants," in Proceedings of the 1980 UCC-ND and GAT Waste Management Semin w, CONF-800416 (Decenber 1980).

T. K. Oakes, J. C. Bird, K. E. Shank, B. A. Kelly, L. L. Harrison, B. R. Clark and F. Rogers, "Waste Oil Nanagement at GRNL," in Proceedings of the $19 Q D$ UCC-ND ard GAT Waste Monagement Seminar, CONF-800416 (Decenber 1980).

E. S. Hougland, T. W. Oakes and K. E. Shank, "Design of the Sulfur Dioxids and Partirslate Air Mnitoring Network for the ORN: Stean Plant," in Proceedings of the $1980 U C C-N D$ and GAT Waste Management Seminar, CONF-800416 (Decenber 1980).

K. E. Shank. T. W. Oakes and J. S. Eldridge, "Quality Assurance Applied to Environmental Surveillance," in Proceedings of tire 1980 UCC-ND and GAT Waste Management Seminar, CONF-800416 (December 1980).

T. W. Oakes, K. E. Shank, J. A. Auxier, J. S. Eldridge, P. Jenkins, G. L. Love, S. G. Oberg, Y. Panesko, B. Selby, W. D. Travers, W. R. Strodl, Environmental Radiological Surveillance: Mechanisms for Information Exchange " Upgrading Invironmental Radiation Data, EPA 520/1-80-012 (August 1980).

J. S. Eldridge, B. Balba, T. W. Oakes, and D. W. Parsons, "Use of BioIndicators for Envi ronmental Surveil lance," Analytical Chemistry Division Sumnary Report, ORNL/CF-80/286 (September 1980).

K. E. Shank and T. W. Oakes, "Environmental Surveillance and Evaluation," Industrial Safety and Applied Health Physics Annul Report for 2979, ORNL-5543 (September 1980).

F. F. Haywood, D. G. Jacobs, H. M. Hubbard, Jr., B. S. Ellis and $W H$. Shinpaugh, Bxilological iuriey of the Inactive Uranium-Mill Tailing at Gunnisor, Colorado, ORNL-5453 (1980). 
F. F. Haywood, W. A. Goldswith, B. S. Ellis, H. M. Hubbard, ir., W. F. Fox and $\boldsymbol{H}$. H. Shinpaugh, Rssessment of the Radiological Impaci of the Inactive Uranium-Hil? Tailings at Hexiocm Hat, Utah, ORNL-5448 (1980).

F. F. Haywood, M. A. Coldswith, P. M. Lantz, W. F. Fox, W. H. Shinpaugh

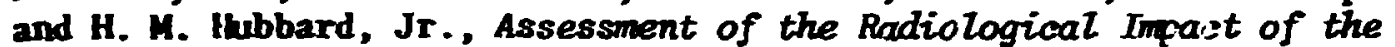
Inactive Unarium-1fill Tailings at Shiprock, Mes Mexico, ORNL-5447 (1980).

F. F. Haywood, T. D. Jones, H. M. Hubbard, Jr., B. S. Ellis and W. H. Shinpaugh, Radiological Survey of the Inactive Uraniron-Mill Tailings at Tuba City, Arizona, ORNL-5450 (1980).

K. E. Shank, T. W. Oakes, J. S. Eldridge and M. A. Montford, Qual ty Assumance Procetures for Environmental Surveillance Activities at Oak Ridge Rational Laboratory, ORNL/TM-7213 (1980).

F. S. Tsakeres, K. E. Shank, M. Y. Chaudhry, S. A. Ahnad, P. M. Dizillo-Benoit and T. W. Oakes, Eadiological Assessment of Residences in the Oak Ridge Area, ORNL/TM-7392/V-1 (October 1980).

L. C. Henley, W. W. Parkinson, Jr. and C. W. Nestor, Jr., "'irinary Excretion of Curium by Two Cases Sustaining a Subcutaneous Intake of Cn $\left(\mathrm{NO}_{3}\right)_{3}$," Health Phys. 39, pp. 977-980, (December 1980).

C. S. Sims and H W. Vickson, "liealth Physics Research Reactor Spectrum Measurements wi th Threshold Detector Units," Health Phys. 38, 76 (1980).

P. T. Perdue, H. :- Dickson, and F. F. Haywood, "Radon Monitoring Instrumentation," dealth Phys. 39, 85 (1980). 


\section{PRESENTATIONS}

J. A. Auxier, "Low-Level Effects of Radiation on thuans," Vanderbilt University, Nashville, Tennesse, March 5, 1980.

J. A. Auxier, "Heal th Effects of Low-Level Radiation," 1980 UCC-ND and Goodyear Atomic Corporation Waste Management Seminar, April 22, 1980.

J. A. Auxier, "The Accident at Three Mile Island," Twenty-fifth Annual Meeting, Health Physics Society, Seattle, Washington, July 25, 1980.

J. A. Auxier, "Occupational Exposure: Expected Health Effects," 1980 Scientific Assembly of the Medical Society of the District of Columbia, White Sulphur Springs, West Virginia, October 25, 1980.

J. A. Auxier, "Low-Level Effects of Radiation: Model Based Upon Ichiban (Japanese) Data," Fall Meeting of Bluegrass Chapter, Health Physics Society, Louisville, Kentucky, November 14, 1980.

J. T. Blackmon and W. J. Huffman, "The Design of Fire Safe Buildings," presented at the Fall Conference of National Fire Protection Association, Phoenix, Arizona, November 1980.

J. T. Blackmon, "Impact of Regulations on Fire Protection Engineering and Design," $\mathrm{KD} / 5077$, presented to the Society uf Fire Protection Engineers, WATTAC Conference, Knoxville, Tennessee, February 20, 1980.

J. T. Blackmon, "The Changing Requirements of Safety/Health Education in Industry," $\mathrm{KD} / 5075$, presented to the Council of Safet) and Health Fducators, Nashville, Tennessee, March 1, 1980.

H. W. Dickson, "Planning for Decommissioning Action," U.S. Department of Energy Decommissioning Criteria Workshop, Kansas City, Missouri, April 15-16, 1980 as an invited paper.

E. L. Keller and W. A. Goldsmith, "Proposed Relationship Between FUSRAP Radiological Monitoring and Certification Contractors," U.S. Department of Energy Decommissioning Critera Workshop, Kansas City, Missouri, April 15-16, 1980 (presented by H. W. Dickson).

H. W. Dickson and C. S. Sims, "Adequacr of Personnel Dosimetry in Mixed Neutron and Gamma Radiation Fields," 25th Annual Meeting of the Health Physics Soiiety, Seattle, Washirgton, July 20-25, 1980.

H. W. Dickson, "Contingency Planning at Multipurpose Nuclear Facilities," Meeting of North Carolina Chapter Health Physics Society, Boone, North Carolina, October 10, 1980. 
B. M. Eisenhower and E. E. Ketchen, "Introjuction to the Hazardou:; Materials Management and Control Program at ORNL," presented to the following ORNL Divisions during 1980: C remical Technology, Chemistry, Engineering, Engineering Physics, Finance and Materials, Information, Operations, Physics, and Plant and Equipnerit.

J. S. Eldridge and T. W. Oakes, "Radionuclide Transport in a Liquid Waste System," presented at the 179th National ACS Meeting, Houston, Texas, March 23-28, 1980.

J. S. Eldridge, T. W. Oakes, and K. E. Shank, "Radionuciide Concentrations in White-Tailed Deer on the Department of Energy's Oak Ridge Reservation," presented at the Health Physics Society Annual Meating, Seattle, Washington, July $20-<5,1980$

E. S. Hougland, T. W. Oakes, and K. E. Shank, "Design of the Sulfur Dioxide and Particulate Air Monitoring Network for the ORNL Steam Plant," presented at the 1980 UCC-ND and GAT Waste Management Seminar, Friendship, Chio, April 22-23, 1980.

E. S. Hougland, T. W. Oakes, and K. E. Shank, "The Use of an Idoine-131 Data Base for Model Validation in the Design of the ORNL Steam Plant Air Quality Monitor Network," presented at the Sympnsium on Intermediate Range Atmospheric Transport Processes and Technology Assessment, Gatlinburg, Tennessee, October 1-3, 1980.

M. A. Montford, K. E. Shank, C. Hendricks, and T. W. Oakes, "Concentration of Fadjonuclides and Stable Elements in Food Products," presented at the 14th Annual Conference on Trace Substances in Environmental Health, University of Missouri, Columbia, Missouri, June 3-6, 1980.

T. W. Oakes and B. A. Kelly, "Environmental Regulations - Past, Present, and Future," presented at the 1980 UCC-ND and C.TT Waste Management Seminar, Friendship, Ohio, April 22-23, 1980.

T. W. Oakes, J. C. Bird, K. E. Shank, B. A. Kelly, L. L. Harrison, B. R. Clark, and F. Rogers, "Waste Oil Management at ORNL," present=d at the 1980 UCC-ND and GAT Waste Management Seminar, Friendship, Ohio, April 22$23,1980$.

T. W. Oakes, K. E. Shank, J. S. Eldridge, D. W. Parsons, i. L. Malone, and H. M. Hubbard, "Distribution of Radionuclides in White Oak Creek and Lake Sediment," presented at the Health Pnysics Society Annual Meeting, Seattle, Washington, July 20-25, 1980.

T. W. Oakes, "Analytical Requirements to Meet Environmental Regulations," presented at the 24 th Conference on Analytical Chemistry in Energy Technology, Gatlinburg, Tennessee, October 7.9, 1980.

T. W. Oakes, "Needs for Better ${ }^{99}$ TC Analysis for Environsental Samples," presented at the 24th Conference on Analytical Chemistry in Energy Technology, Gatlinburg, Tennessee, October 7-9, 1980. 
T. W. Oakes, "Filtration in Environmental Protection," presented at the Dixie Chapter of the Filtration Society, At lanta, Georgia, October 1980.

K. E. Shank, T. W. Oakes, and J. S. Eldridge. "Quality Assurance Applied to Environmental Surveillance," presented at the 1980 UCC-ND and GAT Waste Management Seminar, Friendship, Ohio, April 22-23, 1980.

K. E. Shank, T. W. Oakes, J. C. Bird, and F. S. Tsakeres, "An Assessment of Aquatic Data at Oak Ridge National Laboratory," presented at the Health Physics Society Arinual Meeting, Seattle, Washington, July 20-25, 1980.

D. O. Stroud, J. R. Jones, M. E. Mitchell, T. W. Oakes, M. Sinders, and M. B. Tate, "Waste Cil Disposal at the DOE-Oak Ridge Plants," presented at the 1980 UCC-ND and GAT Waste Management Seminar, Friendship, Ohio, April 22-23, 1980 


\section{LECTURES}

\section{J. A. Auxier}

"Health Physics Challenges," ORAll NRC Health Physics and Radiation Protection Training Course, February 1980.

"Low-Level Effects of Radiation on Humans," University of Tennessee, Knoxville, Tennessee, April 1980.

"the Effects of Low-Level Radiation," Physics Division, Oak Ridge National Laboratory, Oak Ridge, Tennessee, June 1980.

"Nuclear Power and Public Concern," ORAU Traveling Lecture, Bethel College, North Newton, Kansas, November $198 n$.

"Hi roshima to Three-Mile Island: Where Do We Go From Here," wight H. Langham Memorial Lecture, University of Kentucky, Lexington, Kintucky, November 1980

C. D. Berger

"ORNL Participation in Knoxville Academy of Medjcine Mass Casualty Simulat: on," IS\&AALP Division Seminar, January 1980.

"Health Physics and Dosimetry at RI," ORAU Medical and Health Sciences Division Seminar, ORJW, April 1980.

"The Role of a Whole Body Counter in a Post-Reactor Accident Sitliation," Health Physics Society Ann':al Meeting, Seattle, h. hington, July 1980.

"What's So Good About the ORNL Whole Body Counter," IS\&Ahir Division Seminar, December 1980.

"Operational Status of ORNL whole Body Counter Instrumentation: Comparisons Between a flyperpure Germanium Array and a Phoswich Detictor," LASL/DOE Instrumentation Workshop $f_{(, r}$ Low-Level Transuranic Measurements Applied in In-Vivo and Environmental Monitoring, March 1980.

\section{G. H. Burger}

"Presentation of ORNL Supplement to Standard Practice Procedure D-5-29 Safety Revitw and rocumcitation Program," presented to an ad-hoc committee estabiished to assist in preparation and review of the proposed SPP Supplement, November 1980.

H. W. Dickson

"Criticality Dosimetry,' ORAU, Health Physics in Radiation Accidents Seminar, January 1980. 
"Risk from Nuclear Power," Powell High School Senior Science Class, Powell, Tennessee, March 1980.

"Neutron Activation Foils," ORAU, Health Physics and Radiation Protection Course, Apri 11980.

"Basis for necommissioning Criteria," University of Tennesee, Kruxville, Radiation Biology Sewinar, May 1980.

"Reactors," ORAU, Applied Health Physics Ccurse, June 1980.

"Marmary Tumorogenesis in the Sprague Dawley Rat," University of Telunessee, Comparative Animal Research Laboratory, August 1980.

"Criticalıy and Associated Dose Estivates," ORAl REAC/TS Training Course: Health Physics in Radiation Accidents, September 1980.

"Decomissioning of Nuclear Facilities - The Health Physics Role," Luncheon Seminar Series, ISEAHP Division, November 1980.

"Principles of Reactors," ORAU, Applied Heal:h Physics Course, November 1980.

C. E. Haynes

"Transuranium Health Physics," ORAU-NRC Health Physics and Radiation Protection Courst, April 1980.

"ORNL Radiation Safety Practices," "Radioactivity Decontamination at ORNL," and "Emergency Drill Involving Radioactive Macerial," ORAU, Radiation Safety Trainil:g Prngram for Chemical Technology Division personnel, September 1980.

C. H. Miller

"Protective Clothing," ORAU-NRC Health Physics and Radiation Protection Course, Marci 1980.

T. W. Oakes

"Envirormental Surveillance," Chattanooga State Technical Community College, February 1980.

"Environmental Monitoring," REAC/TS Training Course, Medical Planning ano Care in Radiation Accidents, ORAU, March 1980.

"Environmental Problems," Junior Science and Hunanities Symposiun, Oak Ridge National Laboratory, March 1980.

"Environmental Problems," Middle Tennessee State University, Marc', 1980. 
"Water Sampling: Spot Samples," ORAL-NRC Health Physics and Radiation Protection Course, April 1980.

"Water Samiing: Continuous Samples," ORAU-NRC Health Physics and Radiation Protection Course, April 1980.

"White Oak Lake and Dan: A Review and Status Report - 1979," ISEAHP wuncheon Seminar, February 1980.

"Enviromental Monitoring," RFAC/TS Training Course on Medical Planning and Care in Radiation Accidents, ORAU, March 1980.

"Wat ‘r Sampling," ORAU, Applied Health Physics Course, June 1980.

"OPNL Enviromental Activities of Interest to ADBES Divisions," Oak Ridge National Laboratory, June 1980.

"Problems with Impleaenting ORNL Hazardous Materials Program," Joint Meeting UCC-ND Environmental Monitoring and Protection Comittee and GAT Environmental Control Representatives, Y-12 Plant, Oak Ridge, Tennessee, August 1980.

"Disposal of Potentially Explosive Materials," Joint Meeting UCC-ND Environmental Monitoring and Protection Comittee and GAT Environmental Control Representatives, Y-12 Plant, Oak Ridge, Tennessee, August 1980.

"ORNL Committee for the Establishment of Environnental Guidelines for Radioactive Waste Disposal," UCC-ND Workshop on Radioactive Waste Criteria for Engineering Planning and Design, Oak Ridge National Laboratory, August 1980.

"Potential Impact of Environmental Regulations on Teaching and Research Chemical Laboratories," Wake Forest University, October 1980.

"Natural Radioactivity," Physics Department, Clemson University, October 1980.

"Environmental Monitoring," ORAU, Oak Ridge, Tennessee, November 1980.

"Environmental Protection Surveillance and Nuclear Power Plants," Department of Entomology, VPI\&SU, Blacksburg, VA, December 198n. 
TRAINING COURSES

\section{Presented}

C. D. Derger

"Bioassay and Whole Body Counting," MRRPT Certification Course, ORAU, April 1980.

"Radiation Release and Health Effects Lossons from the TMI Incident-hssessment of Oojective Risks for Emergency Prepareiness Planning," Kentucky Special Advisory Cinmittee on Muclear Issues, Northern Kentucky University, Highland Heights, Kentucky, November 1980.

"Hea th Physics and Raciation Accidents," and "Bioassay," REAC/TS Training Course, ORAU, September 1980.

"Labor ztory Assessment of Body Burden," REAC/TS Training Course, ORAU, Novenber 1980.

"Whole Body Counting," Applied Health Physics Course, ORAU, November 1980.

"Health Physics and Dosizetry at Three-Mile Island," CARL, March 1980.

J. R. Muir

"Personnel Monitoring," NRRPT Certification Course, ORAU, March 1980.

Attende-

H. M. Butler

Refresher courses for continuing education credit presented by the Health Physics Society, Annual Meeting, Seattle, Washington, July 1980.

G. H. Burger

Three-day seminar "The Effnctive Manager," sponsored by ORNL and presented by the University of Tennessee, November 1980.

T. J. Burnett

'Mobile Crane and Rigging Fundamentals," Oak Ridge, Tenressee, March 1980.

"Supervisors Derelopment Program," ORNL, April 1980.

M. F. Fair

"Supervisors Development Program," ORNL, April 1980.

"Jr. Science and thuanities Symposium, Beate of Tennesse, ORNL, May 1980. 
D. C. Gary

"Supervisors nevelopment Program," ORNL, April 1980.

"Accident Investigation Refresher Course (MORT), Lake Buena Visia, Florida, September 1980.

M. W. Knazovich

ruass Principles and Practices, ORN, May 1980.

R. E. Mi11spaugh

Taught "Supervi sors Development Program,"ORNL, April 1980.

"National Safety Congress," Chicago, Illinois, October 1980.

A. D. Warden

"Supervisors Development Progran," ORNL, April 1980. 
PROFESSIONAL ACTIVITIES AND ASSNCIATIONS

\section{J. A. Auxier}

Consuitant to Radiation Effects Research Foundation, Japan; Member of Dose Assessment Steering Group, U.S. Department of Energy; Advisor to U.S. Departwent of Justice on I!ealth Physics and Radiation Dosimetry; Meaber of National Acadeny of Sciences Panel on Hiroshima/Nagasaki Occupation Forces; Menber of Subcomittee on Exposure at Tests of Muclear Meapuns, Mational Acadeny of Science; Member of Subcomittee on Radiation Research National Institute of Health; Meaber, National Council on Radiation Protection and Messurements; Member, Arards Comittee, Health Physics Society; Member, Ad Hoc Comittee on Scientific and Public Issues, Health Physics Society; Menber, MCRP Scientific Comittee 34 on Maximu Pernissible Concentrations for Occupational and NonOccupational Exposure, NCRP Scientific Conittee 57 on Internal Enitter Standards, KC:AF Scientific Comittee 63 on Kadiation Exposure Control in Peacetine and Wartine; Delivered Eighth Wright H. Langhan Memorial Lecture, University of Kentucky; Received Meritorious Public Service Medal, Defense Nuclear Agency.

\section{D. Berger}

Participation and Critique, Knoxville Acadeny of Medicine Mass Casualty Simulation, Knoxville, Tennessee; Member Health Physics Society.

\section{G. H. Burger}

Member of Instrument Society of America and American Association for the Advancement of Science.

H. M. Butler

President, East Tennessee Chapter HPS: Member Advisory Comaittee on Muclear Technology, Chattanoog. State Commity College; Member, Adwissions Comittee, Health Physics Society.

\section{T. Dice}

Attended ANS Comaittee 15.14 on Physical Security of Research Reactors, Chicago, May 1980.

H. W. Dickson

Member, Health Physics Society, ..ternational Radiation Protection Association; Member, East Tennesse Chapter HPS; Member, HPS Standards Committee.

\section{J. R. Muir}

Member, Health Physics Sxciety, Rules Comnittee. 


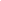


INTERMAL DISTRIBUTION

1. Biology Library

2-3. Central Research Library

4. Laboratory Shift Supervisor

5-7. Laboratory Records Dept.

8. Lab. Records, ORML-RC

9. ORLL Patent Section

10. ORR Y-12 Technical Library Document Reference Section

11. P. G. Agron

12. R. L. Atchley

13. R. L. Auble

14. S. I. Auerbach

15. H. C. Austin

16-35. J. A. Auxier

36. J. M. Barnes

37. E. S. Bomar

38. J. S. Brown, Jr .

3). W. D. Burch

40-43. G. H. Burger

44. T. J. Burnett

45-56. H. M. Butler

57. C. H. Byers

58. W. D. Carcen

59. G. T. Chapman

60. M. M. Chilles

61. R. A. rrowell

62. H. H. DHckson

63. D. G. Doherty

64. D. E. Dunning

65. J. A. Ealy

66. R. S. Edwards

67. K. J. Fallon

68. R. M. Farnham

69. D. E. Perguson

70. J. R. Gissell

71. J. H. Gooch

72. P. H. Green

73. J. H. Greene

74. R. A. Griesemer

75-80. E. D. Gupton

31. C. M. Haaland

82. H. F. Hartman

83. C. R. Haynes

84. R. $P$. H1bbs

85. J. L. Holbrook

86. J. A. Holloway

87. C. C. Hopkins
88. E. J. Howard, Sr .

89. L. L. Huey

90. D. J. Inman

91. A. D. Johnson

92. J. R. Jones

93. S. V. Kaye

94. 0. L. Reller

95. J. A. Holloway

96. M. W. Knazovich

97. R. H. Knight

98. F. C. Kornegay

99. W. C. Kuykenda11

100. E. M. Lees

101. A. W. Longest

102. R. S. Lord

103. H. D. Macliery

104. F. C. Malenschein

105. H. H. Miller, Jr.

106. C. A. M116

107. J. B. Hoody

108. O. B. Horgan

109. F. R. Mynatt

110-119. T. W. Oakes

120. G. H. Oliphant

121. J. A. Otten

122. L. F. Parsly

123. R. G. Pope

124. H. R. Porter

125. J. C. Price

126. S. J. Riashaw

127. J. A. Roberts

128. E. M. Robinson

129. J. B. Ruch

130. J. A. Setaro

131. M. H. Shanks

132. W. D. Shulte

133. S. O. Salth

134. D. R. Stallions

135. P. H. Stelson

136. J. H. Stewart

137. K. H. Somerfeld

138. J. H. Swanks

139. G. E. Testeraan

140. J. G. Tracy

141. H. E. Irame

142. Ken Hallace

143. C. D. Watson 
144. J. R. Weir

145. M. R. Uilkinson
146. K. K. Hilkinson

147. R. H. Winget

\section{EXTEDUAL DiSTRIBUTIOA}

148. Office of Assistant Manager for Energy Research and Deveiopnent DOE-ORO

149-388. Given distribution as show In IID-4500 under Health and Safety category ( 25 copies - YTIS)

389-468. J. W. Haffey, Oak Ridge Assoclated University, P.0. Box 117, Oak Ridge, Tn. 37830 